\title{
DESEMPENHO DO MILHO CONSORCIADO COM DIFERENTES ESPÉCIES DE BRAQUIÁRIAS, EM PIRACICABA, SP
}

\section{GUY MITSUYUKI TSUMANUMA}

Dissertação apresentada à Escola Superior de Agricultura "Luiz de Queiroz", Universidade de São Paulo, para obtenção do título de Mestre em Agronomia, Área de Concentração: Fitotecnia

P I R A C I C A B A

Estado de São Paulo - Brasil

Dezembro - 2004 


\title{
DESEMPENHO DO MILHO CONSORCIADO COM DIFERENTES ESPÉCIES DE BRAQUIÁRIAS, EM PIRACICABA, SP
}

\author{
GUY MitsuYUKI TSUMANUMA \\ Engenheiro Agrônomo
}

\author{
Orientador: Prof. Dr. ANTÔNIO LUIZ FANCELLI
}

\begin{abstract}
Dissertação apresentada à Escola Superior de Agricultura "Luiz de Queiroz", Universidade de São Paulo, para obtenção do título de Mestre em Agronomia, Área de Concentração: Fitotecnia
\end{abstract}

P I R A C I C A B A

Estado de São Paulo - Brasil

Dezembro - 2004 


\section{Dados Internacionais de Catalogação na Publicação (CIP) DIVISÃO DE BIBLIOTECA E DOCUMENTAÇÃO - ESALQ/USP}

Tsumanuma, Guy Mitsuyuki

Desempenho do milho consorciado com diferentes espécies de braquiárias, em

Piracicaba, SP / Guy Mitsuyuki Tsumanuma. - - Piracicaba, 2004.

83 p. : il.

Dissertação (Mestrado) - - Escola Superior de Agricultura Luiz de Queiroz, 2004.

Bibliografia.

1. Brachiaria 2. Competição 3. Consorciação de cultura 4. Integração 5. Milho 6. Sistema de produção I. Título

CDD 633.15

"Permitida a cópia total ou parcial deste documento, desde que citada a fonte - O autor" 


\section{Dedico,}

Aos meus avós, pelo carinho e ensinamentos ao longo da vida.

Aos meus pais, Takeo e Olinda, pelo apoio e amor oferecido ao longo de minha vida.

\section{Ofereço,}

Aos meus irmãos, Anderson e Gilsem, pelo incentivo.

Aos meus tios, por todo carinho.

Ao meu orientador, Prof. Dr. Antônio Luiz

Fancelli pela confiança, pela amizade e pelos valiosos ensinamentos. 


\section{AGRADECIMENTOS}

À Deus, por mais esta graça alcançada.

À minha família que sempre me amparou nas horas difíceis e decisivas da minha vida.

Ao Prof. Dr. Antônio Luiz Fancelli, pelas críticas, pelas sugestões, pelo incentivo e pela orientação para a elaboração desta dissertação.

Ao Prof. Dr. Quirino A. C. Carmello, pela grande amizade e orientação na realização das análises foliares deste experimento.

Ao Prof. Dr. Edwin M. M. Ortega, pelo companheirismo e auxílio na realização das análises estatísticas dos resultados.

Ao Prof. Dr. José Laércio Favarin, pelo companheirismo e atenção.

À mestranda Ana Paula Saldanha de Aguiar, pelo auxílio na apresentação da redação desta dissertação, e principalmente, pelo amor, pelo incentivo, pela compreensão e pela paciência dispensada na realização deste trabalho.

À Fundação de Amparo à Pesquisa do Estado de São Paulo (FAPESP), pela bolsa concedida e a SN pelo apoio financeiro, o qual muito auxiliou na realização das análises químicas de solo e de tecido foliar. 
À Syngenta Seeds e a Naterra Sementes, pela doação de sementes de milho e braquiárias, respectivamente, para o início deste trabalho.

Aos alunos de graduação Marcelo Baldo, Leonardo de Paula, Daniel Bicalho e Ricardo Elias, pelo auxílio na coleta dos dados, durante a fase experimental, e principalmente à Rachel Figueiredo, na fase final da dissertação. Saibam, que mais do que semear conhecimento, cultivaram comigo uma amizade que certamente o tempo amadurecerá.

Aos funcionários do Departamento de Produção Vegetal, pela colaboração na condução do experimento, e a secretária Sílvia e Aparecida, pela atenção; as técnicas de laboratório e as pós-graduandas Luciana Bertolotti e Gláucia Anti do Departamento de Solos e Nutrição Mineral de Plantas, pela colaboração nas análises foliares.

À bibliotecária Silvia Zinsly e a Lurdes F. Gandra, pelo auxílio na formatação do texto e correção das referências bibliográficas.

Aos meus amigos da Pós-graduação, sem os quais essa jornada teria sido muito mais árdua; agradeço especialmente Gilberto Domingues, Juan e Lília del Aguilla e Euro Detomini, pelo companheirismo e solidariedade durante este período.

Àqueles que embora não mencionados, sabem que contribuíram na realização deste trabalho. 


\section{SUMÁRIO}

Página

LISTA DE FIGURAS................................................................................. ix

LISTA DE TABELAS....................................................................................

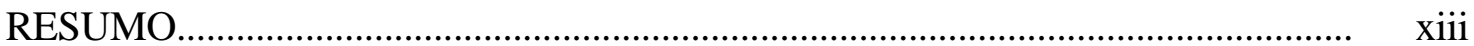

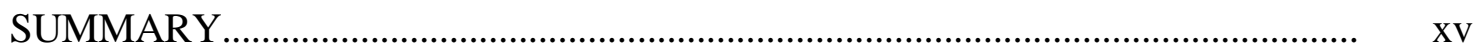

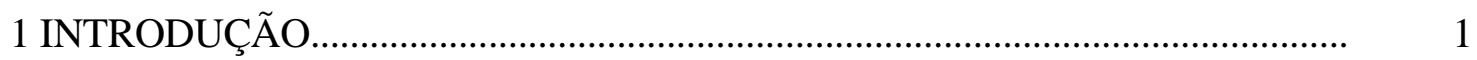

2 REVISÃO DE LITERATURA................................................................. 3

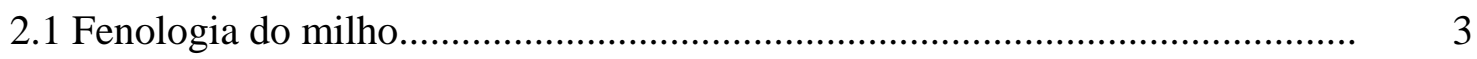

2.2 Principais espécies de braquiárias ............................................................... 4

2.2.1 Brachiaria brizantha...........................................................................

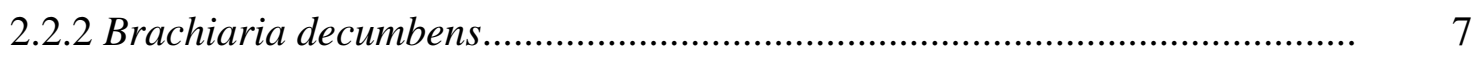

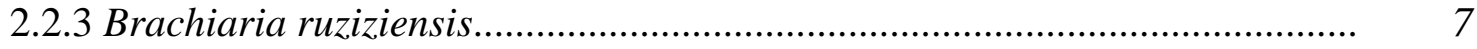

2.3 Implantação do consórcio de milho-braquiária.............................................. 8

2.4 Ações de interferência de braquiárias consorciadas com milho....................... 11

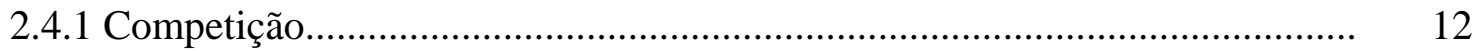

2.4.1.1 Competição por água............................................................................ 14

2.4.1.2 Competição por luz............................................................................... 15

2.4.1.3 Competição por nutrientes..................................................................... 18

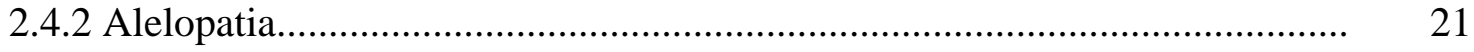

2.4.2.1 Efeitos da alelopatia na consorciação.................................................... 22

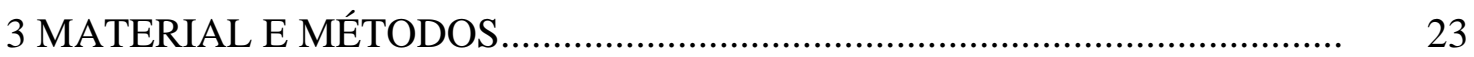


3.1 Caracterização do local e da área experimental............................................ 23

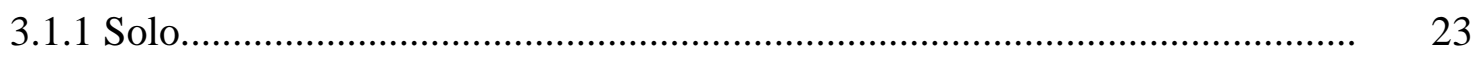

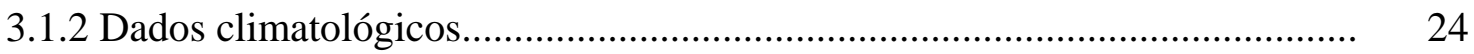

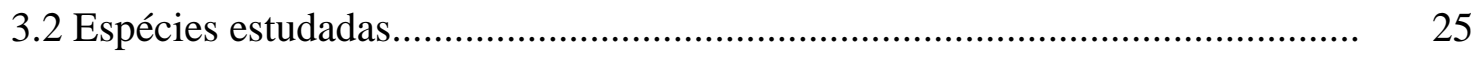

3.3 Épocas de semeadura das braquiárias....................................................... 26

3.4 Tratamentos estudados e delineamento experimental................................... 26

3.5 Condução do experimento...................................................................... 29

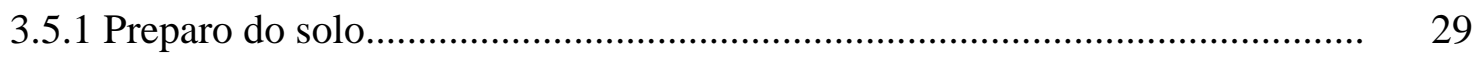

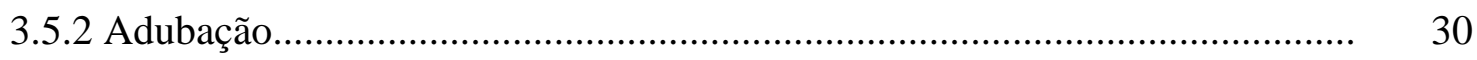

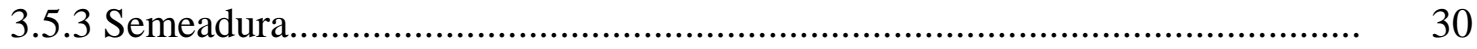

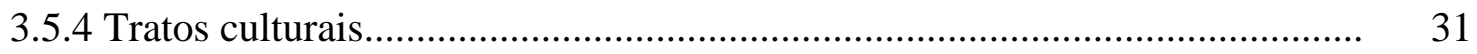

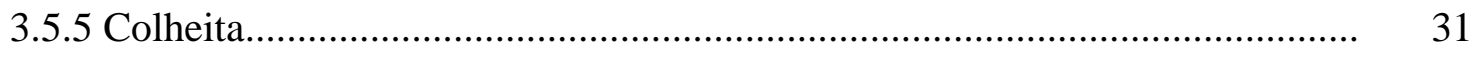

3.6 Avaliação fitotécnica da cultura do milho..................................................... 32

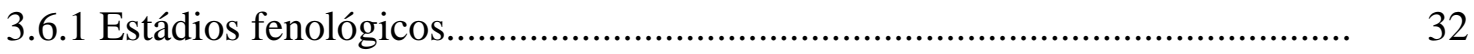

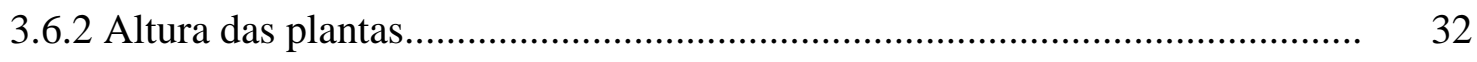

3.6.3 Número de folhas................................................................................ 32

3.6.4 Índice de área foliar.......................................................................... 33

3.6.5 Diâmetro médio do colmo....................................................................... 33

3.6.6 Análise de tecido foliar........................................................................ 33

3.6.7 Componentes de produção.......................................................................... 34

3.6.7.1 Número médio de grãos por espiga....................................................... 34

3.6.7.1.1 Número médio de grãos por fileira...................................................... 34

3.6.7.1.2 Número médio de fileiras por espiga.................................................. 34

3.6.7.2 Massa de mil grãos............................................................................... 35

3.6.7.3 Avaliação da sanidade de grãos na espiga............................................... 35

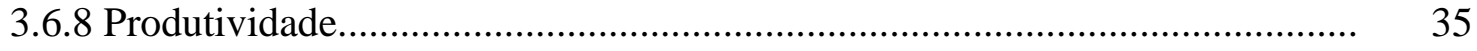

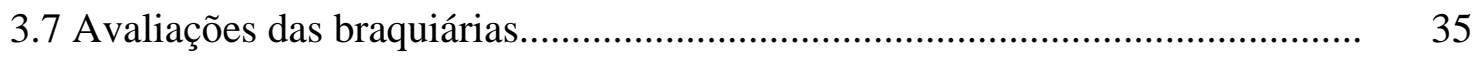

3.7.1 Produção de massa verde e seca da parte aérea........................................... 35

3.7.2 Produção de massa seca do sistema radicular............................................ 36

3.7.3 Supressão de plantas daninhas............................................................. 36 


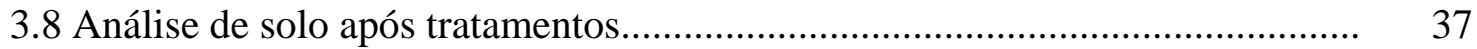

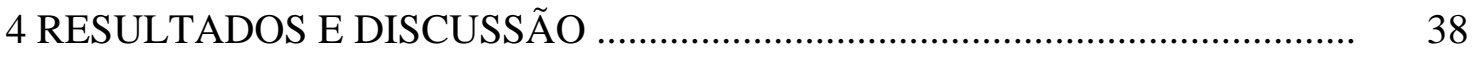

4.1 Avaliação fitotécnica do milho.................................................................... 38

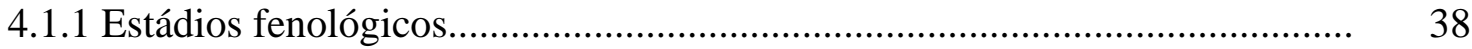

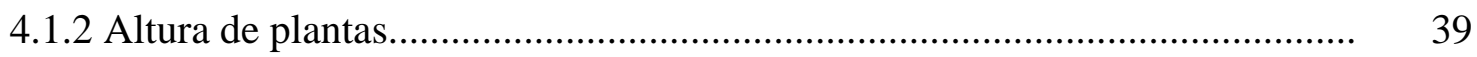

4.1.3 Número de folhas............................................................................. 40

4.1.4 Índice de área foliar................................................................................... 41

4.1.5 Diâmetro médio do colmo..................................................................... 41

4.1.6 Análise de tecido foliar........................................................................ 42

4.1.7 Componentes de produção..................................................................... 44

4.1.7.1 Número médio de grãos...................................................................... 44

4.1.7.2 Massa de mil grãos............................................................................ 44

4.1.7.3 Avaliação da sanidade de grãos na espiga................................................ 45

4.1.7.4 Produtividade ................................................................................. 46

4.2 Avaliações referentes às braquiárias........................................................... 47

4.2.1 Produção de massa verde e seca da parte aérea............................................ 47

4.2.2 Produção de massa seca do sistema radicular............................................. 49

4.2.3 Supressão de plantas daninhas................................................................ 50

4.3 Considerações Finais................................................................................ 57

5 CONCLUSÃO

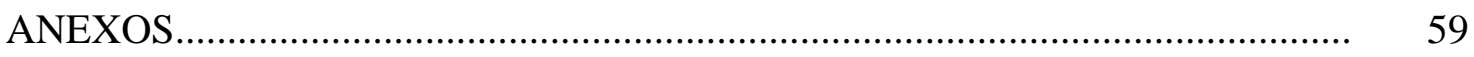

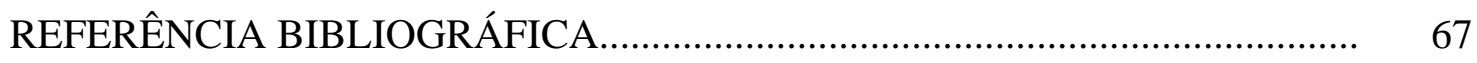

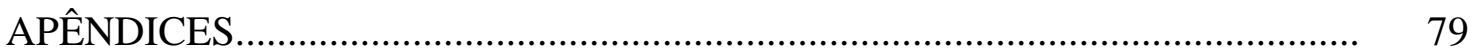




\section{LISTA DE FIGURAS}

Página

1 Esquematização de uma parcela........................................................................ 31

2 Valores médios de altura de plantas de milho em função dos tratamentos

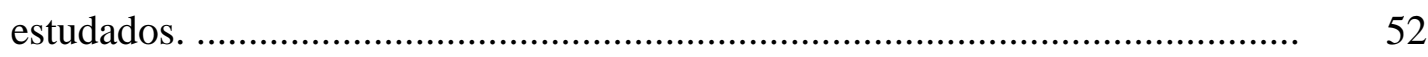

3 Valores médios de número de folhas de plantas de milho em função dos tratamentos estudados............................................................................ 52

4 Valores médios de índice de área foliar de plantas de milho em função dos tratamentos estudados................................................................................ 52

5 Valores médios de diâmetro de colmo de milho em função dos tratamentos

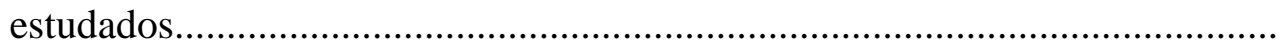

6 Valores médios do número de fileiras presentes nas espigas de milho, em função dos tratamentos estudados. ................................................................... 53

7 Valores médios do número de grãos apresentados nas fileiras da espiga de milho, em função dos tratamentos estudados..................................................... 53

8 Valores médios da massa de mil grãos de milho, em função dos tratamentos

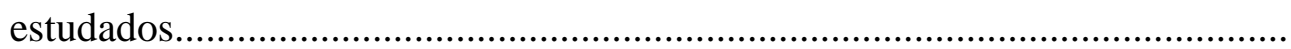

9 Valores médios das notas de severidade de doença nos grãos presentes nas espigas de milho, em função dos tratamentos estudados..................................... 54

10 Valores médios de produtividade de milho, em função dos tratamentos estudados. 
11 Produção de massa verde da parte aérea das braquiárias, realizada em três

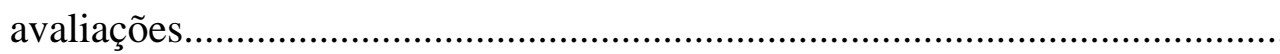

12 Produção de massa seca da parte aérea das braquiárias, realizada em três

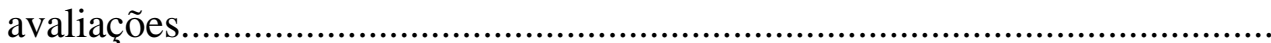

13 Produção de massa seca de raízes das braquiárias, em duas profundidades e

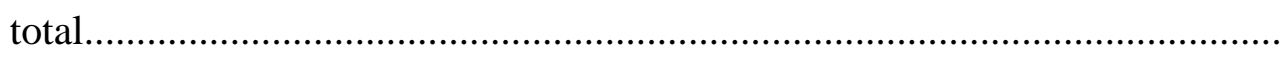

14 Supressão de plantas daninhas pelas braquiárias, em três avaliações realizadas após a roçagem das braquiárias. 


\section{LISTA DE TABELAS}

Página

1 Caracterização dos estádios fenológicos da cultura de milho (adaptado de

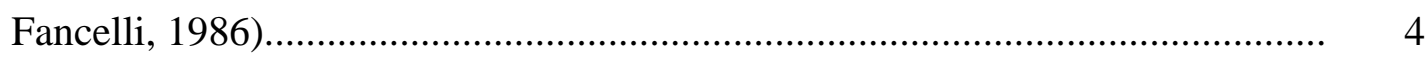

2 Resultado da análise química de solo da área experimental.............................. 24

3 Dados climatológicos relativos ao período de condução do experimento (out/2003 a set/2004)........................................................................... 25

4 Descrição dos tratamentos estudados............................................................... 27

5 Esquema de análise de variância para os dados relativos às avaliações de altura, número de folhas, índice de área foliar e diâmetro de colmo....................

6 Esquema de análise de variância para os dados relativos às avaliações de análise foliar, componentes da produção e produtividade, para a cultura do milho e à matéria seca de raiz das braquiárias...................................................

7 Esquema de análise de variância para os dados de massa seca e verde (parte aérea de braquiária) e de supressão de plantas daninhas................................... $\quad 29$

8 Estádios Fenológicos do Milho, durante a condução do experimento..................

9 Valores médios de altura da planta $(\mathrm{H})$, número de folhas (NF), índice de área foliar (IAF) e diâmetro de colmo (DC) relacionados às plantas de milho em

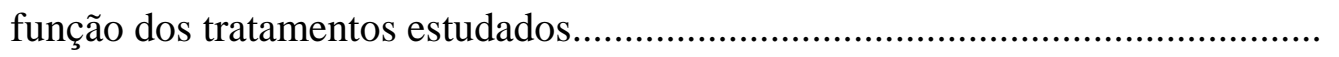

10 Teores foliares dos macronutrientes, Nitrogênio (N), Fósforo (P), Potássio (K), Cálcio (Ca), Magnésio (Mg) e Enxofre (S) no milho em diferentes tratamentos. 
11 Teores foliares dos micronutrientes, Boro (B), Cobre (Cu), Ferro (Fe), Manganês (Mn) e Zinco (Zn) na planta de milho em diferentes tratamentos......

12 Valores médios de número de fileiras (NF), número de grãos na fileira (NGF), massa de mil grãos (M 1000), nota de severidade (S) e produtividade (PROD). 45

13 Produção de massa verde (MV) das espécies de braquiárias (média de três avaliações)

14 Produção de massa seca (MS) das espécies de braquiárias (média de três avaliações)

15 Massa seca (MSraiz) de raízes das braquiárias, em duas profundidades e total.. 50

16 Supressão de plantas daninhas pelas braquiárias, em três avaliações realizadas após a roçagem das braquiárias. 


\title{
DESEMPENHO DO MILHO CONSORCIADO COM DIFERENTES ESPÉCIES DE BRAQUIÁRIAS, EM PIRACICABA, SP
}

\author{
Autor: GUY MITSUYUKI TSUMANUMA \\ Orientador: Prof. Dr. ANTÔNIO LUIZ FANCELLI
}

\section{RESUMO}

A consorciação do milho com gramíneas forrageiras pode ser utilizada tanto para renovações de pastagens, como para a formação de cobertura morta de qualidade e longevidade para o sistema de Plantio Direto. O objetivo deste trabalho foi avaliar as interações e interferências de diferentes espécies de braquiárias no desempenho da cultura de milho, bem como determinar qual das espécies seria a mais adequada para o sistema de consórcio. O experimento foi conduzido em Nitossolo eutrófico típico, sob pivô central, em área experimental pertencente ao Departamento de Produção Vegetal da Escola Superior de Agricultura “Luiz de Queiroz”/ Universidade de São Paulo, situado no Município de Piracicaba, SP. O delineamento experimental utilizado foi o de blocos ao acaso com sete tratamentos e quatro repetições. Os tratamentos foram constituídos da combinação de três espécies de braquiárias (Brachiaria decumbens, Brachiaria brizantha e Brachiaria ruziziensis) semeadas em duas épocas (concomitantemente ao milho e quando o milho apresentava quatro folhas totalmente expandidas), acrescido de um tratamento testemunha (milho solteiro). Com relação ao milho, os resultados evidenciaram ausência de diferença estatística entre os tratamentos para as seguintes variáveis: altura de plantas; índice de área foliar; diâmetro do colmo; análise foliar; número de fileiras de grãos; número de grãos por espiga; peso de mil grãos e 
produtividade. Todavia, o número de folhas de milho e a sanidade de espigas foram afetados pelos tratamentos estudados. Assim, o tratamento 6 (B. brizantha semeada na quarta folha do milho) propiciou maior número de folhas em plantas de milho e a $B$. decumbens semeada na mesma data do milho propiciou menor taxa de grãos deteriorados na espiga em comparação ao tratamento testemunha. Com relação às braquiárias, todas as espécies semeadas na primeira época (semeadura concomitante ao milho) diferiram daquelas semeadas quando o referido cereal apresentava quatro folhas, quanto à produção de massa verde e seca. A B.decumbens e a B. brizantha, semeadas na primeira época, apresentaram maior produção de matéria seca de raiz em comparação à $B$. brizantha, semeada na segunda época. Após a roçagem, a produção de massa verde e seca de parte aérea das $B$. decumbens e $B$. brizantha semeadas na primeira época foi superior à produção da B. ruziziensis semeada na segunda época. A B. decumbens, independentemente da época de semeadura, apresentou maior efeito supressor de plantas daninhas. Assim, a análise e a interpretação dos resultados, permitiram concluir que a presença das braquiárias, indiferentemente à época de semeadura, não afeta o desenvolvimento e a produtividade do milho, demonstrando a viabilidade técnica de sistemas consorciados de produção. Entretanto, a presença do milho influencia negativamente o acúmulo de fitomassa das braquiárias, principalmente, quando estas são semeadas quando o milho apresenta quatro folhas. Para a formação de pastagens, as forrageiras estudadas apresentam melhor desempenho e produtividade quando implantadas na mesma data da cultura do milho. Dentre as braquiárias, destaca-se a $B$. decumbens pela quantidade de forragem produzida, bem como pelo efeito supressor de plantas daninhas. Entretanto, para a produção de forragem a B. brizantha apresenta resultados semelhantes a $B$. decumbens. 


\title{
GROWTH AND YIELD OF MAIZE INTERCROPPED WITH DIFFERENT SPECIES OF BRACHIARIA, IN PIRACICABA, SP
}

\author{
Author: GUY MITSUYUKI TSUMANUMA \\ Adviser: Prof. Dr. ANTÔNIO LUIZ FANCELLI
}

\section{SUMMARY}

Maize intercropped with grass can be used both to pasture renewals and to quality and longevity of soil cover formation in no-tillage system. The present work aimed at evaluating the interactions and interferences of different brachiaria species on maize yield, as well as determining which would be the most appropriate species for a intercropping system. The experiment was carried out in Piracicaba, São Paulo State, Brazil (Universidade de São Paulo, ESALQ), in a typical Rhodudalf soil, under central pivot, in an experimental area belonging to the Department of Crop Production. The experimental design was in randomized blocks with seven treatments and four replications. The treatments consisted of a combination of three brachiaria species (Brachiaria decumbens, Brachiaria brizantha and Brachiaria ruziziensis) sowed in two different dates (together with maize and when maize had four fully expanded leaves), as well as a control treatment (single maize). In relation to maize, the results showed no statistical differences among the treatments for the following parameters: plant height; leaf area index; stem diameter; foliar analysis; number of grain rows; number of grain per rows in ear; thousand grain weight and productivity. However, the number of maize leaves and the sanity of ears were affected by the treatments. Thus, treatment 6 ( $B$. 
brizantha sowed at the four leaves stage of maize) favored larger number of leaves on maize plants, and $B$. decumbens sowed on the same dates as maize presented lower rate of deteriorated grains per spike in comparison to the control treatment. In relation to brachiaria, all of the species sowed on the first date (concomitant sowing with maize) differed from those sowed at the four leaves stage of maize, for green and dry mass production. The $B$. decumbens and B. brizantha, sowed in the first time, presented larger production of root dry matter in comparison to B. brizantha, sowed on the second date. After cutting, the green and dry mass production of shoot of $B$. decumbens and $B$. brizantha sowed on the first date was superior to the green and dry mass production of $B$. ruziziensis sowed on the second date. $B$. decumbens, regardless of the sowing date, presented a greater suppressor effect on weeds. The analysis and the interpretation of the results allowed to conclude that the presence of brachiaria, regardless of sowing date, doesn't affect the development and the productivity of maize, thus demonstrating the technical viability of intercropped systems of production. However, the presence of maize negatively influences the biomass accumulation of brachiaria, especially, when these are sowed when maize has four leaves. For pasture formation, the studied forage grasses present better yield and productivity when sowed at the same date as maize. Among the brachiaria, B. decumbens stands out for the amount of forage produced, as well as for the suppressor effect on weeds. However, for forage production, B. brizantha presents similar results to $B$. decumbens. 


\section{INTRODUÇÃO}

A consolidação de uma agricultura racional, lucrativa e sustentável depende do reconhecimento da fragilidade do ecossistema modificado pelo homem para a realização dessa atividade econômica. Assim, o emprego de técnicas e tecnologias apropriadas, bem como o desenvolvimento de novas alternativas agrícolas fundamentadas no enfoque sistêmico e na utilização racional de técnicas agronômicas, poderiam auxiliar na busca do tipo de agricultura almejada.

$\mathrm{Na}$ atual conjuntura da agropecuária nacional, observa-se a plena expansão do sistema de Plantio Direto, a consorciação de lavouras com forrageiras, a preocupação com a utilização racional de água e defensivos, além da constante preocupação com a competitividade e sustentabilidade do agroecossistema, já que estes são componentes necessários para a viabilidade desta atividade econômica.

A recuperação da produtividade, tanto de áreas agrícolas como de pastagens, devido ao manejo inadequado e à repetição das técnicas de criação, têm sido muito onerosa, sendo por vezes, inviável, sob o ponto de vista econômico e energético. Ao se conjugar essas duas atividades, a complementação resultante, poderá manter e/ou aumentar o nível de produtividade, assim como conferir sustentabilidade à atividade rural. A renovação de pastagens, mediante a consorciação de culturas de grãos, com gramíneas forrageiras, segundo vários estudos, constitui-se em uma alternativa economicamente viável.

O milho é um dos mais importantes cereais cultivados e consumidos no mundo, por sua composição química e valor nutritivo, assumindo relevante papel sócio-

econômico nas mais diversas cadeias agroindustriais. Os estudos realizados com a 
cultura do milho, por sua vez, têm envolvido avanços significativos, nas mais diversas áreas do conhecimento agronômico, quando comparada a outras culturas de interesse.

Porém, constata-se grande lacuna relacionada ao estudo das interações e mudanças no comportamento desta espécie, quando submetida ao consórcio com braquiárias.

Assim, o presente trabalho teve por objetivo principal avaliar as interações entre as diferentes espécies de braquiárias semeadas em duas épocas, em relação à cultura de milho; bem como determinar a espécie de forrageira mais adequada para o sistema de produção mencionado. 


\section{REVISÃO DE LITERATURA}

\subsection{Fenologia do milho}

De acordo com Fancelli (1986) o conceito de fenologia envolve o conhecimento de todas as etapas de crescimento e desenvolvimento da vida vegetal, uma vez que a reunião desses conhecimentos, de forma ordenada e concisa, possibilita a determinação das relações e do grau de influência dos fatores envolvidos no processo produtivo, favorecendo o estabelecimento de estratégias de manejo e de tomada de decisão.

O ciclo da cultura de milho, segundo Fancelli (1994), compreende diferentes etapas de desenvolvimento, tais como: i) emergência (cerca de 7 a 10 dias): período da semeadura até o aparecimento da plântula; ii) crescimento vegetativo (com extensão variável, dependendo da precocidade do material), da emissão da segunda folha até o inicio do florescimento; iii) florescimento (cerca de 8 a 10 dias): período desde o inicio da polinização até o inicio da frutificação; iv) frutificação (cerca de 50 a 60 dias): etapa compreendida entre o início do enchimento dos grãos até o inicio da maturação; v) maturação (cerca de 25 a 35 dias): etapa desde o final da maturação até o ponto de maturidade fisiológica.

A divisão considerada das etapas de desenvolvimento em estádios facilita o manejo (referência exata) e o estudo da cultura, bem como objetiva a possibilidade do estabelecimento de correlações entre elementos fisiológicos, bioquímicos, climatológicos, fitogenéticos, entomológicos, fitopatológicos e fitotécnicos com o desempenho da planta e ao atributo de interesse (Fancelli, 1986). O mesmo autor destaca, ainda, que o manejo fundamentado em simples escala de tempo pode ocasionar equívocos, dependendo das condições que a cultura for submetida. 
Tabela 1. Caracterização dos estádios fenológicos da cultura de milho (adaptado de Fancelli, 1986)

\begin{tabular}{|c|c|}
\hline Estádios & Descrição \\
\hline 0 (ou V0) & Emergência \\
\hline 1 (ou V4) & Quatro folhas completamente expandidas \\
\hline 2 (ou V8) & Oito folhas completamente expandidas \\
\hline 3 (ou V12) & Doze folhas completamente expandidas \\
\hline 4 (ou R1) & Emissão do pendão \\
\hline 5 (ou R2) & Florescimento e polinização \\
\hline 6 (ou R3) & Grãos leitosos \\
\hline 7 (ou R4) & Grãos pastosos \\
\hline 8 (ou R5) & Grãos farináceos (formação de dentes) \\
\hline 9 (ou R6) & Grãos farináceos duros (dentados) \\
\hline 10 (ou R7) & Maturidade fisiológica \\
\hline
\end{tabular}

\subsection{Principais espécies de braquiárias}

A área de pastagens cultivadas no Brasil apresentou um incremento de 250\% de 1970 a 1995 (Zimmer \& Euclides Filho, 1997), principalmente devido à incorporação do Cerrado ao sistema produtivo agropecuário. Dos $207.10^{6}$ ha do Cerrado, aproximadamente, $75.10^{6}$ ha são ocupados por pastagens nativas e $42.10^{6}$ ha por pastagens cultivadas (Yokoyama et al., 1995). Entretanto, 80\% são consideradas como pastagens de baixa produtividade (Corazza, 2002).

A distribuição das precipitações e as limitações químicas naturais dos solos comprometem a produção de forragem natural, tanto em sua qualidade quanto em sua quantidade. A mudança da vegetação natural para pastagens cultivadas representou uma alternativa para aumentar a produção de carne com a introdução de plantas forrageiras de origem africana com grande capacidade de adaptação aos solos e climas. Estas plantas forrageiras podem ser separadas em três gêneros: Brachiaria (aproximadamente 
80\% das pastagens cultivadas), Panicum e Andropogon, conforme relatado por Savidan et al. ${ }^{1}$,citados por Corazza (2002).

A braquiária é a gramínea forrageira mais cultivada no país e vem substituindo cada vez mais áreas de pastagens nativas, cujas baixas taxas de proteína bruta e produtividade, são responsáveis por perdas de peso animal na estação seca. Neste contexto, Macedo (1995), relata que cerca de 40 milhões de hectares (85\% da área de pastagens dos Cerrados) são cobertos por pastagens de braquiária, formando extensos monocultivos, especialmente no Brasil Central e Amazônia. As vantagens deste capim relacionam-se à sua adaptabilidade às mais adversas condições de solo e clima, proporcionando produções satisfatórias mesmo nestas condições (Soares Filho, 1994).

Segundo Botrel et al. (1999), as braquiárias, em geral, têm se mostrado como plantas de elevado potencial de produção de matéria seca, além de serem satisfatoriamente aceitas pelos bovinos, proporcionando ganhos significativos de peso. Entretanto, para que o potencial dessas pastagens se manifeste, é necessário que se utilizem espécies forrageiras adaptadas às condições edafoclimáticas da região. O uso de forrageiras não apropriadas poderá resultar em efeitos negativos, não só do ponto de vista econômico, como também ecológico.

Dentre as espécies de braquiárias empregadas em sistemas agropecuários, merecem especial destaque a Brachiaria brizantha, a Brachiaria decumbens e a Brachiaria ruziziensis.

\subsubsection{Brachiaria brizantha}

A Brachiaria brizantha (Hochst ex. A. Rich) Stapf é uma espécie cosmopolita, característica de solos vulcânicos do continente africano, originária de região com

\footnotetext{
1 SAVIDAN, Y.; JANK, J.; SOUZA, F.H.D. de; BOOK, A. Preliminary evaluation of Panicum maximum germplasm in Brazil. In: INTERNATIONAL GRASSLAND CONGRESS, 15., Kyoto, 1985. Proceeding. Japan: The Science Council of Japan/ The Japanese Society of Grassland Science, 1985. p. 117-118.
} 
precipitação anual em torno de $700 \mathrm{~mm}$ e cerca de oito meses de seca, além de apresentar grande diversidade de tipos (Rayman ${ }^{2}$, citado por Nunes et al., 1984).

$\mathrm{Na}$ literatura é descrita como planta perene, de 1,5 a 2,5 m de altura, cespitosa, muito robusta, com bainhas pilosas e lâminas foliares linear-lanceoladas, apresentando rizomas muitos curtos e encurvados. Ainda, é indicada para solos de média à alta fertilidade, tendo boa resistência à cigarrinha das pastagens, porém baixa tolerância ao encharcamento (Soares Filho, 1994; Skerman \& Riveros, 1990).

A variedade Marandu, originária do Zimbábue e lançada pela Empresa Brasileira de Pesquisa Agropecuária (EMBRAPA) em 1984, tem porte ereto, 1,5 a 2,5 m de altura, com colmos iniciais prostrados e afilhos (perfilhos) cada vez mais eretos, ao longo do crescimento da touceira. A referida espécie também apresenta intenso afilhamento nos nós superiores dos colmos floríferos, além de possuir pêlos na porção apical dos entrenós, bainhas pilosas e lâminas largas e longas, com pouca pubescência na face ventral e glabras na face dorsal. As inflorescências podem atingir até $40 \mathrm{~cm}$ de comprimento, com 4 a 6 racemos (Nunes et al., 1985). Segundo o mesmo autor, a mencionada forrageira apresenta adequado valor nutritivo, alta produção de matéria verde e grande quantidade de sementes viáveis. De acordo com Ghisi \& Pedreira (1986), o cultivar Marandu tem maior tolerância a cigarrinhas das pastagens e a condições de baixas temperaturas e seca. É muito exigente em fertilidade do solo, sendo persistente e com boa capacidade de rebrota. A produção média anual é de 8 a $20 \mathrm{t} \mathrm{ha}^{-1}$ de matéria seca, de acordo com a adubação realizada. Sua propagação é feita por sementes, na quantidade de 6 a $8 \mathrm{~kg} \mathrm{ha}^{-1}$, com 25\% de valor cultural, numa profundidade de 2 a $4 \mathrm{~cm}$ (Alcântara \& Bufarah, 1988).

2 RAYMAN, P.R. Minha experiência com Brachiaria brizantha. Campo Grande, MS: Rayman’s Seeds Sementes de Pastagens Tropicais, 1983. 3 p. 


\subsubsection{Brachiaria decumbens}

A Brachiaria decumbens Stapf. cv. Basilisk é uma poácea originária da África tropical. Têm hábito decumbente, altura de 60 a $100 \mathrm{~cm}$, possui folhas pubescentes e compactas, inicialmente mais eretas, com enraizamento vigoroso dos estolões (Seiffert, 1980; Alcântara \& Bufarah, 1988). Ainda, apresenta boa cobertura do solo, além de ter alta resistência ao pisoteio. Vegeta bem em solos argilosos ou arenosos, sendo indicada para solos de baixa a média fertilidade, tendo alta resistência à seca, não apresentando, contudo, resistência ao ataque de cigarrinhas e nem ao encharcamento. Possui desenvolvimento satisfatório no verão, tendo sua produção afetada por baixas temperaturas, sofrendo muito com geadas. Produz de 9 a 11 toneladas de matéria seca por hectare em 4 cortes, bem como se propaga por mudas (estolões) ou por sementes que apresentam dormência e necessitam de armazenamento de, aproximadamente, 12 meses antes da semeadura (Bognan, 1997; Seiffert, 1980; Ghisi \& Pedreira, 1986; Alcântara \& Bufarah, 1988; Soares Filho, 1994; Alcântara, 1993). Segundo Skerman \& Riveros (1990), a mencionada espécie, quando estabelecida, tem habilidade para suprimir a competição de plantas invasoras, dificultando, por outro lado, a consorciação com leguminosas.

\subsubsection{Brachiaria ruziziensis}

Brachiaria ruziziensis Germain \& Evrard cv. Comum é uma espécie perene, de folhas mais lisas, suberetas e de coloração mais clara, que chega a atingir até 1,5 metro de altura. É menos eficiente para promover o recobrimento do terreno, por não enraizar nos nós inferiores, porém é adaptada a vários tipos de clima, sendo mais produtiva em áreas tropicais com elevados índices pluviométricos (EMBRAPA,1983).

Esta espécie tem exigência mínima por solos com boa drenagem de perfil e média fertilidade, apresentando alta proteção contra a erosão (Alcântara et al., 1993). Ainda, possui baixa resistência à seca, à geada e a cigarrinhas; no entanto, têm grande aceitabilidade pelos bovinos, quando comparada a $B$. decumbens, além de boa 
habilidade para competir com plantas invasoras, formando pastagens densas. Sua semeadura deve ser realizada na estação chuvosa, com o uso de mudas ou sementes (Skerman \& Riveros, 1990).

\subsection{Implantação do consórcio de milho-braquiária}

Sistemas de produção fundamentados em consórcio de espécies são utilizados, há séculos, pelos agricultores. O sistema consorciado tem apresentado maior estabilidade à produção pelo fato de assegurar maior grau de diversificação, apresentando geralmente menor incidência de pragas e doenças, por oferecer substrato descontínuo a estes organismos.

A formação de pastagens em associação a uma cultura anual é uma técnica viável, uma vez que o estabelecimento da forrageira pode ser beneficiado pelo preparo de solo e pela adubação, necessários para o bom desenvolvimento da cultura anual (Cruz Filho, 1990). O sucesso da tecnologia depende ainda de outras condições, que precisam ser observadas, além de uma série de condições locais que devem ser atendidas. Solos apropriados para a agricultura, máquinas e equipamentos, condições de transporte e armazenamento, fornecimento de insumos, entre outros fatores, segundo Zimmer et al. (1994), devem ser analisados ou viabilizados para que esta atividade seja rentável. Carvalho \& Cruz Filho (1985), salientam ainda a importância da compatibilidade entre as espécies, a fertilidade do solo e o método de semeadura como fatores que interferem no estabelecimento da forrageira associada.

Os sistemas consorciados, de acordo com Ferreira (2000), podem ser divididos em sistemas aditivos e de substituição. No sistema aditivo, ocorre a semeadura de uma das culturas no mesmo arranjo do monocultivo, sendo simultaneamente adicionada a segunda cultura, aumentando a população de plantas na área. No consórcio de substituição, uma segunda cultura é implantada quando a principal já foi instalada. A conseqüência desse sistema é que, geralmente, ocorre prejuízo no estabelecimento e no rendimento forrageiro, conforme constatado por Souza Neto (1993), quando a $B$. brizantha foi semeada após a emergência do milho. 
De acordo com Klutchcouski \& Aidar (2003) em experimentos com 18 híbridos de milho em diferentes condições edafoclimáticas, consorciados com braquiárias, apenas três deles sofreram reduções significativas de produtividade. Na maioria dos locais constatou-se a tendência para o aumento no rendimento do sistema consorciado, provavelmente devido a não aplicação de herbicida graminicida em pós- emergência, reduzindo possíveis efeitos fitotóxicos. Observou-se, ainda, maiores populações finais nas parcelas consorciadas em relação ao monocultivo. Da mesma forma, os experimentos relatados demonstraram que o aumento da fertilidade do solo, proporcionou melhor desenvolvimento do milho.

Carvalho et al. (1990), em ensaio de recuperação de pastagens degradadas de $B$. decumbens cv. Basilisk na região dos Cerrados com: (1) introdução de leguminosas; (2) revolvimento do solo e (3) culturas anuais adubadas (milho, arroz e sorgo); observaram que o milho foi a cultura que apresentou a maior produção de grãos e que mais afetou a produção de forragem da gramínea e das leguminosa. Esse fato foi atribuído à sua maior competitividade nas fases iniciais, mesmo em solos de baixa fertilidade e ao menor ataque de pragas com as forrageiras estudadas, sendo, conseqüentemente, a cultura mais viável economicamente para a recuperação de pastagem degradada.

Alvim et al. (1989) realizaram ainda outros métodos de estabelecimento de braquiária com milho no Centro Nacional de Pesquisa de Gado de Leite (CNPGL/ EMBRAPA) em Coronel Pacheco, MG. Neste mesmo experimento, a semeadura à lanço de $B$. decumbens entre covas de milho e, posteriormente, incorporada por um leve revolvimento do solo, não prejudicou excessivamente a produção de grãos e favoreceu o estabelecimento da forrageira. A semeadura em covas separadas proporcionou razoável estabelecimento da braquiária após a colheita do milho, segundo os mesmos autores.

Para Willey \& Osiru (1972) quando as culturas associadas são semeadas em linhas separadas e não à lanço, há um favorecimento no manejo, uma vez que as espécies podem ser manejadas como culturas individualizadas.

Vieira (1974) estudando o efeito de quatro espaçamentos na produção de $B$. decumbens,constatou produção de biomassa semelhante entre os espaçamentos 0,40 m e $0,80 \mathrm{~m}$, que por sua vez superaram os resultados obtidos nos espaçamentos $1,20 \mathrm{~m}$ e 
1,40 m. A justificativa dada pelo autor, para os resultados obtidos, foi baseada na menor presença de plantas daninhas nos espaçamentos mais estreitos.

Macedo \& Zimmer (1990), obtiveram adequado estabelecimento de B. brizantha cv. Marandu em plantio simultâneo com milho, após cultivo de soja, por dois anos, em solo arenoso, em Bandeirantes, MS. Neste experimento, foram efetuadas duas épocas de semeadura em estações consecutivas, sendo a primeira em Janeiro e a segunda em Outubro. Cinco densidades de semeadura da forrageira foram testadas, com e sem a cultura do milho. A semeadura da braquiária foi realizada à lanço, incorporada com grade niveladora, seguida pela semeadura do milho com 4 a 5 sementes por metro e espaçamento de 1 metro entre linhas. As produções de milho foram significativamente afetadas nas épocas mais tardias e a densidade de semeadura da forrageira influenciou linear e negativamente a produção de grãos. Na semeadura de segunda época (Outubro), a produção da forrageira foi reduzida em mais de 50\%, quando consorciada, comparada à semeadura da braquiária solteira. Ainda, a produção de milho nesta época foi menos afetada pela braquiária, independentemente da densidade de semeadura testada.

Segundo Klutchcouski et al. (2000), o consórcio pode ser implantado simultaneamente à semeadura da cultura anual ou cerca de 10 a 20 dias após a emergência destas. Para Fancelli ${ }^{3}$, a época adequada para a implantação de braquiárias, objetivando a preservação da produtividade do milho deverá ser correspondente à emissão da $3^{\mathrm{a}} / 4^{\mathrm{a}}$ folha do referido cereal.

A época de semeadura da forrageira na entrelinha da cultura acompanhante é um fator determinante na competição por água, nutrientes e, principalmente, luz, pois as gramíneas tropicais são pouco tolerantes ao sombreamento (Ludlow, 1978). Alvim et al. (1989), verificaram a eficiência de métodos de semeadura de $B$. decumbens em associação à cultura do milho sobre o estabelecimento da forrageira, por meio de duas épocas e diferentes métodos de semeadura. A competição foi mais acentuada no cultivo associado quando a braquiária foi semeada 21 dias após o milho, porém a forrageira teve melhor desempenho quando semeada simultaneamente ao milho. Há de se considerar que a concentração de nutrientes existentes, tanto nas covas exclusivas de braquiária,

\footnotetext{
${ }^{3}$ FANCELLI, A. L. Comunicação verbal, 2004..
} 
como naquelas de dupla semeadura, pode ter favorecido a população inicial da forrageira, quando comparada à semeada a lanço.

Para Blanco (1972), a ocorrência de plantas daninhas, 45 dias após a emergência do milho, não afetou o potencial produtivo da cultura. Todavia, Souza Neto (1993), ressalta que após esse período, a competição pode se tornar mais desfavorável a forrageira, devido ao sombreamento e a competição imposta pelo referido cereal.

Duarte et al. (1994), avaliando o crescimento de três gramíneas forrageiras (Brachiaria brizantha cv. Marandu, B. dictyoneura CIAT 6133 e Pennisetum purpureum cv. Mott) estabelecidas em cultivo intercalado com milho ou vigna, concluíram que a semeadura simultânea das gramíneas com as culturas citadas reduziram a velocidade de estabelecimento das forrageiras, sendo a magnitude deste efeito variável em função da espécie utilizada na associação.

O hábito de crescimento também se constitui em importante fator a ser considerado na competição. Assim, a associação com o milho mostrou-se promissora para o estabelecimento das gramíneas, uma vez que os efeitos detrimentais da competição exercida por esta cultura são temporais e menos pronunciados em uma espécie rasteira e de lento crescimento como a Brachiaria dictyoneura.

Estudos realizados em diversas localidades do Brasil Central sugerem que, em condições de boa fertilidade de solo, sem a presença de altas infestações de plantas daninhas de folha estreita e com uma densidade de plantas de braquiária desejável (8 a $10 \mathrm{pl} \mathrm{ha}^{-1}$ ), o consórcio de milho com braquiárias pode dispensar o uso de herbicidas graminicidas, contribuindo para a redução de custos em relação ao sistema solteiro (Cobucci \& Portela, 2003).

\subsection{Ações de interferência de braquiárias consorciadas com milho}

Interferência é o efeito combinado das pressões ambientais diretas e indiretas que ocorrem entre plantas; ou seja, o conjunto de ações que incide numa determinada cultura em decorrência da presença de uma outra comunidade vegetal presente num determinado local (Pitelli, 1985). 
São conhecidas interações positivas e negativas, sendo a competição pelos recursos do ambiente a mais importante interação negativa identificada em um sistema biológico (Radosevich, 1996; Wilson, 1988).

O conhecimento da maneira como a forrageira e a cultura são afetadas em um consórcio é de grande importância para que haja êxito na formação de pastagens e produção satisfatória da cultura.

Dentre os fatores relacionados às ações de interferência podem ser citados à competição por água, luz, nutrientes e os efeitos alelopáticos.

\subsubsection{Competição}

Entende-se por competição a distribuição dos recursos limitantes do crescimento como água, dióxido de carbono, nutrientes e luz, entre as espécies no agroecossistema e a eficiência de cada uma delas em utilizar esses recursos para a produção de biomassa (Rohrig \& Stulzel, 2001). Além destes recursos, pode-se citar ainda o espaço vital. Assim, a disposição das plantas no consórcio, época e forma de estabelecimento da forrageira e níveis de adubação, influem acentuadamente na competição entre plantas (Souza Neto, 1993). Neste contexto, a resposta das plantas aos recursos segue uma curva padrão, sendo a resposta pequena se o recurso é limitado e máxima quando o ponto de saturação é atingido, podendo até declinar quando em excesso (Radosevich, 1996). A competição por água, nutrientes e luz é difícil de ser separada, já que esses recursos estão interligados, pois a deficiência em um deles afeta a capacidade competitiva das espécies cultivadas pelos demais (Fleck, 1992).

As condições ambientais, como $p H$, densidade do solo e outros fatores, influenciam diretamente a utilização dos recursos pelas plantas, podendo limitar a resposta da planta tanto pela carência quanto pela abundância, até que seja atingido um nível ideal. Entretanto, competição somente é constatada quando os competidores utilizam recursos de sobrevivência em intensidade superior à capacidade do meio em fornecer estes recursos. Essa situação pode ser evidenciada em condições de 
sombreamento, onde um dos competidores impede o acesso do outro (Mather, 1961; Pitelli, 1985).

Os fatores que determinam a maior competitividade entre as espécies são: o porte e a arquitetura da planta; a maior velocidade de germinação e estabelecimento da plântula; a maior velocidade do crescimento e maior extensão do sistema radicular; a menor suscetibilidade da espécie às intempéries climáticas (como veranico e geadas); o maior índice de área foliar e, a maior capacidade de produção e liberação de substâncias químicas com propriedades alelopáticas (Silva et al., 2004).

Uma planta é considerada competidora eficaz quando utiliza rapidamente um determinado recurso ou quando é capaz de continuar seu desenvolvimento mesmo com níveis escassos desses recursos no ambiente (Radosevich, 1996). O milho é considerado um exímio competidor quando combinado com plantas de menor porte, como é o caso das braquiárias.

Segundo Silva (1997), as espécies do gênero Brachiaria apresentam rápido crescimento inicial do sistema radicular e também da parte aérea, em condições de verão. Em conseqüência disso, essas espécies apresentam acentuada competição por água, nutriente e luz com as culturas, principalmente quando presentes no início do seu desenvolvimento.

A forrageira quando estabelecida em consórcio mantém seu crescimento sob o sombreamento proporcionado pelo milho. Esse comportamento também foi observado por Dias Filho (2000), que constatou em espécies de braquiária, particularmente, $B$. brizantha sob sombreamento artificial, plasticidade fenotípica quanto à captura de radiação em resposta ao sombreamento, e como conseqüência, a capacidade de manter o crescimento mesmo com restrição de luz.

Segundo Fleck et al. (2004), os efeitos negativos da competição sobre o rendimento das culturas geralmente decrescem com o intervalo de tempo entre a emergência da cultura e das espécies concorrentes.

De acordo com Cobucci (2003), a B. brizantha em monocultivo apresenta, a partir dos 45 dias após a emergência (DAE), um aumento na taxa de acúmulo de biomassa seca, sendo que a taxa de acúmulo do milho nestas mesmas condições é 
superior à da forrageira, principalmente quando este se beneficia da adubação nitrogenada aplicada em cobertura.

Outros trabalhos realizados em argissolos argilosos na Universidade Federal de Viçosa demonstraram a ocorrência de um certo atraso no estabelecimento da forrageira, beneficiando a produção de grãos de milho em razão do aumento da taxa de crescimento da forrageira coincidir com o final do período crítico de competição com a cultura. Contudo, este comportamento além de estar relacionado ao ambiente edáfico, representado pela textura e drenagem, também pode ser influenciado pelas condições climáticas (precipitação, insolação e temperatura) e pelas características das espécies utilizadas (Silva et al. 2004).

Ainda, a menor produção de biomassa seca total da parte aérea do milho em convivência com $B$. brizantha nas densidades de quatro e oito plantas por vaso, foi constatada por Silva et al (2004), quando o estabelecimento da forrageira ocorreu uma semana antes e na mesma época de emergência do milho. No entanto, o milho aos 14 DAE não foi afetado pela forrageira, independentemente da densidade estudada.

O princípio da competição baseia-se no fato de que as primeiras plantas que surgem no solo se estabelecem efetivamente e dificultam o desenvolvimento das demais. Portanto, é imprescindível fornecer à cultura condições adequadas para que essa se estabeleça antes do surgimento da vegetação espontânea (plantas daninhas).

\subsubsection{Competição por água}

A competição por água é o fator mais limitante da distribuição e produtividade de espécies vegetais pelo mundo (McWilliam, 1986). As plantas desenvolveram várias respostas ou mecanismos fisiológicos e morfológicos para suportar períodos de estresse hídrico, desenvolvendo adaptações tanto na parte aérea quanto no sistema radicular (Jefferies, 1993).

As espécies tolerantes à seca, como a Brachiaria brizantha, apresentam uma tolerância plasmática em baixo potencial de água e, freqüentemente, em baixo potencial osmótico. Desse modo, segundo estudos realizados por Silva (1997), maiores teores de 
água no solo propiciaram maior índice de consumo de água que, por sua vez, está diretamente relacionado com o maior acúmulo de biomassa seca pela $B$. brizantha.

O efeito do estresse hídrico em milho é função do estádio de desenvolvimento da cultura, da duração e severidade do estresse e da eficiência no uso da água pelas plantas (Lorens et al., 1987). Geralmente, a competição por água induz a planta a competir ao mesmo tempo por luz e nutrientes, especialmente nitrogênio e carbono.

Entende-se por uso eficiente da água (UEA) a relação existente entre a biomassa seca produzida e a unidade de massa de água absorvida. O milho, por apresentar rota fotossintética $\mathrm{C}_{4}$, tem melhor UEA que as espécies com rota fotossintética $\mathrm{C}_{3}$, porém não apresenta vantagem sobre aquelas que possuem rota fotossintética semelhante, como a braquiária. Segundo Morris \& Garrity (1993), em cultivos consorciados, há um melhor UEA comparado aos cultivos solteiros, desde que as espécies consorciadas não estejam sob severo déficit hídrico. A espécie dominante dentro de um consórcio, eleva seu UEA por meio da absorção de parte da água disponível no período de convivência, reduzindo a água disponível às plantas dominadas (Chastain \& Grabe, 1989).

Macedo \& Zimmer (1990), visando à implantação de pastagens com semeadura simultânea de milho e B. brizantha, realizada em Janeiro e Outubro, constataram interferência significativa no rendimento de grãos de milho quando a semeadura de ambas as espécies foi realizada em Janeiro, época desfavorável ao desenvolvimento desse cereal. Entretanto, na semeadura realizada em Outubro, a produção de grãos foi mais elevada e menos afetada pela forrageira, devido às condições favoráveis de precipitação e temperatura.

\subsubsection{Competição por luz}

A radiação luminosa é um recurso vital para a fotossíntese e o desenvolvimento das plantas, exercendo um papel importante na habilidade competitiva entre espécies. A competição pela luz é complexa e sua magnitude é influenciada pela espécie e rota fotossintética das espécies envolvidas.

No sistema de produção consorciado, o balanço de energia proporcionado pela 
luminosidade no interior do dossel torna-se mais complexo quando comparado ao dossel homogêneo de monoculturas, devido às diferenças entre espécies, como altura, arquitetura do dossel, taxa fotossintética e partição de fotoassimilados (Sinoquet \& Bonhomme, 1992; Keating \& Carberry, 1993). Assim, quando as plantas consorciadas apresentam diferentes estruturas de crescimento ou diferentes distribuições da área foliar, ocorre um melhor aproveitamento da luz. Para Willey (1979), uma outra maneira de se aumentar a eficiência no aproveitamento da luz, poderia ser obtida com a utilização de diferentes níveis de exigências.

De acordo com Rajcan \& Swanton (2001), a quantidade e a qualidade são os componentes da radiação que afetam o resultado da competição entre plantas. A intensidade da radiação interceptada pela planta - componente quantitativo - determina a fotossíntese no dossel, enquanto a qualidade da radiação é a variável que regula a morfologia da planta. Ambos os componentes são modificados numa situação de competição no consórcio, em comparação ao monocultivo e, como conseqüência, alterase a acumulação de biomassa, a produção de grãos e a morfologia das espécies consorciadas (Baumann et al., 2001). Nos cultivos consorciados as espécies normalmente diferem em altura e em distribuição das folhas no espaço, entre outras características morfológicas que podem levar as plantas a competir pela radiação fotossinteticamente ativa (RFA), ou seja, a radiação utilizada pelas plantas.

Plantas que crescem sob ou dentro do dossel de outras culturas são expostas à reduzida quantidade de RFA e também recebem radiação de qualidade diferente daquela recebida pelas que crescem em pleno sol. A radiação no interior do dossel, principalmente nas camadas mais baixas, é enriquecida pela radiação vermelho-distante (700-740 nm), que segundo Holt (1995), é a radiação resultante da absorção seletiva da radiação encontrada no espectro vermelho $(660-670 \mathrm{~nm})$ dos pigmentos fotossintéticos e da reflexão e transmissão da radiação vermelhodistante pelas folhas verdes. Dessa forma, a relação vermelho-distante - vermelho (VD/V) da radiação nas camadas inferiores do dossel é superior àquela encontrada sobre o dossel das culturas consorciadas.

A maior relação VD/V nas plantas, é um indicativo de competição, pois induz a 
maior alocação de fotoassimilados para o desenvolvimento das folhas e dos ramos em detrimento do sistema radicular (Salisbury \& Ross, 1991).

Segundo Wallace et al. (1991), uma importante característica da cultura do milho refere-se a maior parte da RFA ser capturada na camada superior do dossel, pelas folhas mais jovens e eficientes, e menos de $10 \%$ da RFA incidente chega a atingir as camadas inferiores do dossel abaixo de $1 \mathrm{~m}$. Assim, a competição direta pela RFA incidente é desfavorável às culturas dominadas no dossel do milho. Além disso, o milho possui habilidade competitiva devido aos diferentes materiais genéticos disponíveis quanto a altura, IAF, ângulo de folhas e taxas de crescimento (Begna, 2001).

O índice de área foliar (IAF) representa a quantidade de área foliar por unidade de área de solo, sendo a característica mais utilizada na descrição das relações entre a radiação e o dossel das culturas. O IAF também define a habilidade do dossel de determinada cultura em interceptar a RFA incidente, sendo um importante fator na determinação do acúmulo de biomassa pelas plantas. O IAF das espécies cultivadas também pode ser reduzido pela alta pressão de competição exercida pelas plantas daninhas, principalmente gramíneas $\mathrm{C}_{4}$, afetando diretamente a produção e comprometendo a integridade deste sistema.

Silva et al. (2004), avaliando a evolução do IAF de milho e B. brizantha, em consórcio e monocultivo, verificaram rápido desenvolvimento foliar da cultura em comparação à forrageira. A B. brizantha quando consorciada, apresentou menor IAF do que em monocultivo, onde o IAF máximo foi de 5,6 aos 133 DAE, enquanto o milho, consorciado ou solteiro, apresentou IAF máximo de $4,38 \mathrm{~m}^{2}$ de folhas por $\mathrm{m}^{2}$ de solo, aos 83 DAE.

Segundo Dias Filho (2000 e 2002), a B. brizantha apresenta determinada plasticidade fenotípica e tolerância em resposta ao sombreamento, porém reduz sua capacidade fotossintética. Em ambiente sombreado, essa mesma espécie apresenta maior área foliar específica, maior razão de área foliar e menor relação entre clorofila a e b, economizando o nitrogênio necessário à captura de luz; bem como baixo ponto de compensação luminoso, promovendo um balanço positivo de carbono para manutenção do seu crescimento. Assim, a produtividade do milho é favorecida e viabilizada pela 
baixa competição exercida pela $B$. brizantha no consórcio. Além disso, uma das condições necessárias para se obter vantagens potenciais na associação de gramíneas forrageiras cultivadas com culturas anuais, visando a formação de pastagens, é a utilização de forrageiras com tolerância ao sombreamento.

\subsubsection{Competição por nutrientes}

A interferência das forrageiras no estado nutricional da cultura, bem como no rendimento de grãos, depende das condições de solo, de clima, dos cultivares utilizados e do manejo empregado (Silva et al., 2004).

O tipo e a disponibilidade do nutriente influenciam a competição por este fator, assim como a eficiência de uso pelas plantas e a quantidade de precipitação pluvial. A disponibilidade do nitrogênio no solo e sua distribuição na planta pode ser alterada pela presença do competidor durante o crescimento e desenvolvimento do milho (Rajcan \& Swanton, 2001). Assim, segundo Tollenaar et al. (1994), sob alta competição ocorre a diminuição da concentração de clorofila nas folhas, reduzindo a taxa fotossintética, o acúmulo de biomassa e a produção de grãos.

Para Machado (2001), o Nitrogênio é o nutriente que mais limita o crescimento da pastagem, sendo que a falta deste nutriente é considerada um dos principais fatores que levam a degradação do sistema. O Nitrogênio, além de atuar sobre a sustentabilidade da comunidade de plantas, torna-se também o principal modulador da produtividade agrícola, em sistemas de produção. Assim, quando o suprimento de Nitrogênio no solo não é adequado para atender às exigências da planta, a produção de forragem é substancialmente reduzida (Robbins et al., 1989; Boddey et al., 1996).

A adição de Nitrogênio a partir da atmosfera (geralmente em quantidade

inferiores a $10 \mathrm{~kg} \mathrm{~N} \mathrm{ha}{ }^{-1}$, juntamente com o Nitrogênio disponibilizado a partir da mineralização da matéria orgânica e da decomposição de resíduos de origem animal e vegetal, pouco auxiliam no atendimento das exigências de Nitrogênio da planta forrageira. Boddey et al. (1996) estimaram que pastagens solteiras nos Cerrados 
apresentariam um déficit de Nitrogênio, considerando apenas a ciclagem de nutrientes, da ordem de $58 \mathrm{~kg} \mathrm{~N} \mathrm{ha}^{-1} \mathrm{ano}^{-1}$.

Alvim et al. (1990), avaliando a produção de matéria seca (MS) de 5 acessos $^{4}$ de braquiária e diferentes doses de nitrogênio, verificaram que a produção anual de MS de todos os acessos responderam aos níveis de Nitrogênio aplicado (0; 75 e 150 kg N ha-1), sendo a $B$. brizantha a variedade que mostrou maior potencial de produção de MS e a maior eficiência relativa em relação as demais, para as doses de Nitrogênio utilizadas. Entretanto, na ausência deste elemento, esta variedade foi a que produziu menor quantidade de MS, enquanto que os cultivares $B$. decumbens foram os mais produtivos. B. ruziziensis e $B$. humidicola mostraram-se mais sensíveis às condições climáticas adversas ao crescimento da planta.

O Fósforo (P) é um dos fatores mais limitantes da produção forrageira em pastagens, principalmente naquelas onde não são realizadas adubações de manutenção. Isto é devido a sua baixa biodisponibilidade, tanto pelo seu nível de reserva como pela elevada capacidade de retenção de fosfatos pelo solo. Deste modo, o Fósforo é responsável pela rápida queda da capacidade produtiva das pastagens cultivadas, comprometendo a sustentabilidade do sistema.

Martinez (1980) testou níveis críticos de Fósforo em sete espécies de gramíneas tropicais e concluiu que a Brachiaria humidicola e a Hyparrhenia rufa foram as espécies mais eficientes na absorção e utilização desse nutriente. Em ordem decrescente, seguiram-se as espécies Pennisetum purpureum, Panicum maximum, Digitaria decumbens, Brachiaria decumbens e Melinis minutiflora.

Em trabalho semelhante Nunes et al. (1985), constataram que o cultivar Marandu tem boa resposta a adubação fosfatada, aumentando a produção de matéria seca, de 8,6 para $20 \mathrm{t} \mathrm{ha}^{-1}$, com a aplicação de $400 \mathrm{~kg} \mathrm{P} \mathrm{ha}^{-1}$. O mesmo cultivar apresenta ainda boa tolerância a altos níveis de Alumínio e Manganês no solo, não respondendo significativamente a calagem. A aplicação de calcário, no entanto, não deve ser descartada, devido ao fornecimento de Cálcio e Magnésio ao solo.

\footnotetext{
${ }^{4}$ amostra de germoplasma representativa de um ou vários indivíduos de uma população.
} 
Sanchez \& Salinas (1987) concluíram que existem diferenças entre espécies cultivadas e variedades dentro da mesma espécie na tolerância a baixos níveis de $\mathrm{P}$ disponível no solo. A informação levantada sugere que as espécies ou variedades mais tolerantes a baixos níveis de $\mathrm{P}$ disponível têm rendimentos mais altos em baixos níveis de $\mathrm{P}$ aplicado do que as espécies ou variedades mais sensíveis. Os níveis críticos para as espécies forrageiras tropicais são, provavelmente, mais baixos do que para as culturas anuais (Lobato et. al., 1985).

Em experimento conduzido por Corrêa \& Haag (1993 a) em casa de vegetação, não foram constatadas diferenças entre $B$. brizantha e $B$. decumbens quanto à exigência de P para o estabelecimento das gramíneas. Entretanto, quando o mesmo experimento foi instalado em condições de campo (Corrêa \& Haag, 1993 b), a B. brizantha apresentou-se mais exigente em fósforo que a variedade $B$. decumbens. Os níveis críticos de fósforo na planta também foram variáveis entre as espécies, sendo os maiores teores verificados na B. brizantha.

Premazzi (1991), submetendo B. brizantha a níveis crescentes de saturação por bases, com a finalidade de se determinar o nível que possibilita na maior produção de matéria seca, concluiu que 43\% de saturação proporcionou a máxima produção. Em relação à composição mineral da parte aérea e raízes, os nutrientes que melhor caracterizaram o efeito do tratamento no solo foram Cálcio e Magnésio, cujos teores aumentaram, e Manganês e Zinco, cujos teores diminuíram em função dos níveis de

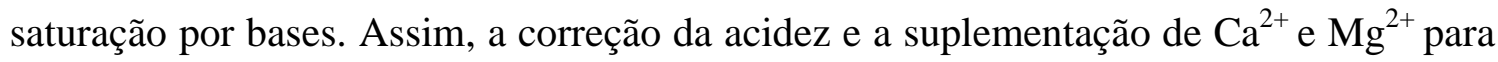
as plantas são fundamentais para a produção de grãos e forragem em solos ácidos.

Com relação aos micronutrientes, Mattos \& Colozza (1986) salientam que pastagens apresentam resposta significativa à adubação com micronutrientes somente quando são supridas as necessidades dos macronutrientes, principalmente o $\mathrm{P}$, na fase de estabelecimento e o Nitrogênio, em cobertura. Assim, em sistemas consorciados com pastagens, o fornecimento de micronutrientes pode se constituir em importante fator de garantia para a obtenção de produtividades satisfatórias das espécies envolvidas.

A adubação, para minimizar a competição por nutrientes, pode ser eficiente em alguns casos, porém pode agravar o problema se mal empregada. Segundo Fleck (1992), 
adubações em grande quantidade, por aumentarem tanto o crescimento das espécies concorrentes quanto da cultura, intensificam a competição, beneficiando a espécie mais eficiente no uso desse recurso.

Sistemas consorciados são viáveis quando as plantas associadas possuem período de crescimento similar, porém com picos de demandas de nutrientes em fases distintas, atendendo as exigências das plantas, não excedendo a taxa pela qual os nutrientes podem ser supridos pelo solo (Willey, 1979).

\subsubsection{Alelopatia}

Entre plantas, a competição por elementos vitais como água, luz, nutrientes e dióxido de carbono $\left(\mathrm{CO}_{2}\right)$ é bastante conhecida, mas além dela, algumas plantas podem exercer uma inibição química sobre a germinação e o desenvolvimento de outras, conhecida por alelopatia ou efeito alelopático (Lorenzi, 1982).

Algumas espécies possuem substâncias alelopáticas que podem prevenir a decomposição, interferir na dormência das sementes e gemas, além de afetar as relações com outras plantas. Entre os efeitos e/ou sintomas observados pode-se citar: a) redução na germinação, b) deformação e morte de plântulas, c) diminuição na absorção e eficiência de nutrientes, d) redução no crescimento e no perfilhamento de plantas e e) diminuição da produtividade (Rice, 1984; Hale \& Orcutt, 1987; Rodrigues et al., 1993).

Os compostos químicos com potencial alelopático estão presentes em quase todos os tecidos da planta, incluindo folhas, caules, raízes, rizomas, flores frutos e sementes. As plantas podem sintetizar mais de uma substância tóxica, e esta, por sua vez, pode ter mais de uma função (Almeida, 1988).

Até o momento, não se conhece, detalhadamente, todos os produtos químicos com propriedades alelopáticas, nem tampouco a forma como são sintetizados. Dentre as substâncias de maior ocorrência estão os ácidos fenólicos, terpenóides, cumarinas, flavonóides, ácido ferúlico, juglona, taninos, ácido gálico, ácido vanílico, ácido cinâmico, escopoletina e vários glicosídeos (Wittaker \& Feeny, 1971; Rice, 1984; Almeida, 1988 e Rodrigues et al., 1992). 


\subsubsection{Efeitos da alelopatia na consorciação}

O estudo da alelopatia em pastagens é complexo devido à natureza das interações observadas. Sendo assim, a ocorrência do pisoteio, da deposição irregular de excrementos na área e o do pastejo seletivo pelos animais poderiam causar o aumento de espécies menos palatáveis ou o desaparecimento das espécies menos tolerantes ao pastejo, sem que efetivamente ocorra algum efeito alelopático (Rodrigues et al., 1993).

Informações sobre a alelopatia em pastagens são ainda incipientes, porém o reconhecimento do potencial desses efeitos é extremamente importante para permitir a adoção de práticas agronômicas, possibilitando o sucesso no estabelecimento de outras plantas no consórcio com braquiárias.

Assim, o conhecimento aprofundado dos efeitos alelopáticos poderia ser utilizado para controlar o banco de sementes ou para estimular a germinação uniforme dessas sementes, de forma a reduzir o uso potencial de herbicidas.

O estabelecimento de pastagens consorciadas em diversos locais do Brasil, muitas vezes, não tem obtido sucesso e este fato tem sido atribuído às dificuldades de manejo de plantas com exigências fisiológicas e taxas de crescimento diferentes. Contudo, nesse caso particular, não pode ser desconsiderada a hipótese de que as dificuldades de estabelecimento e a falta de persistência, de um dos componentes da pastagem consorciada estejam ligados a incompatibilidade das espécies, devido a efeitos alelopáticos. Assim, antes de se recomendar sistemas consorciados de produção, seria aconselhável a avaliação do potencial alelopático das espécies consideradas (Rodrigues et al. 1992).

Neste contexto, várias pesquisas demonstram que espécies de braquiárias possuem propriedades alelopáticas, que interferem no desenvolvimento de muitas espécies acompanhantes (Chou, 1977; Chou et al., 1989 e Stanizio et al., 1991). 


\section{MATERIAL E MÉTODOS}

\subsection{Caracterização do local e da área experimental}

O experimento foi conduzido em condições de campo, sob pivô central, na área de experimentação sob a égide do Departamento de Produção Vegetal da Escola Superior de Agricultura “Luiz de Queiroz”, da Universidade de São Paulo - ESALQ/USP, situado no Município de Piracicaba, SP, geograficamente localizado na latitude $22^{\circ} 42^{\prime} 30$ ’’ e longitude 47030’00’', a uma altitude de, aproximadamente, 550 m, em relação ao nível do mar.

O clima da região é correspondente a Cwa, segundo a classificação de Köppen, ou seja, mesotérmico tropical úmido com 3 meses mais secos (Junho, Julho e Agosto) e com concentração de chuvas no verão.

Ainda, a referida área experimental apresentava infestação média de plantas daninhas, representada principalmente por: picão preto (Bidens pilosa L.), falsa-serralha (Emilia sonchifolia (L.) DC.), capim-massambará (Sorghum halepensis (L.) Pers.), trapoeraba (Commelina virginica L.), tiririca (Cyperus rotundus L.), caruru (Amaranthus viridis L.), apaga-fogo (Alternanthera tenella Colla), capim marmelada (Brachiaria plantaginea (Link) Hitch.) e corda de viola (Ipomoea spp.).

\subsubsection{Solo}

O solo da área experimental foi caracterizado morfologicamente como Nitossolo eutrófico típico, com declividade média ao redor de 5\% (relevo suave ondulado).

A análise de solo foi realizada pelo Laboratório de Análises de Solos do Departamento de Solos e Nutrição Mineral de Plantas da Escola Superior de Agricultura 
“Luiz de Queiroz”, cujos resultados são apresentados na tabela 2. A partir dos resultados desta análise, foram efetuados os cálculos referentes à adubação de semeadura e da aplicação antecipada de potássio.

Tabela 2. Resultado da análise química de solo da área experimental

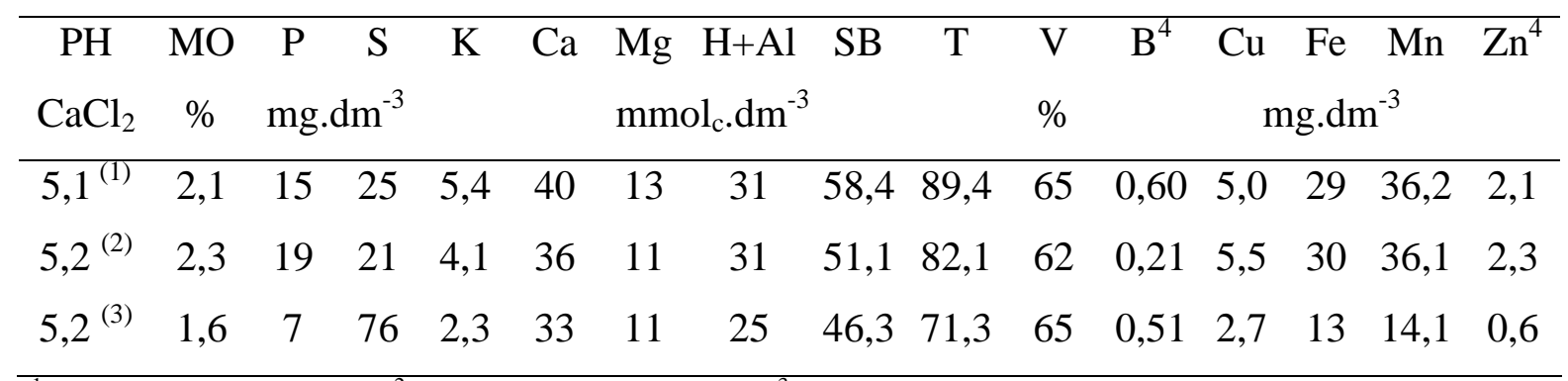

${ }^{1}$ Profundidade 0 a $10 \mathrm{~cm} ;{ }^{2}$ Profundidade 10 a $20 \mathrm{~cm} ;{ }^{3}$ Profundidade 20 a $40 \mathrm{~cm}$;

${ }^{4}$ Boro extraído em água quente e Zinco, Cobre, Ferro e Manganês através da solução DTPA.

\subsubsection{Dados climatológicos}

Os dados climatológicos relativos ao período experimental são apresentados na tabela 3 e foram coletados no posto meteorológico automatizado pertencente ao Departamento de Ciências Exatas da ESALQ/USP, instalado em Piracicaba, SP. 
Tabela 3. Dados climatológicos relativos ao período de condução do experimento (out/2003 a set/2004); Piracicaba, SP

\begin{tabular}{|c|c|c|c|c|c|c|c|c|c|}
\hline \multirow{2}{*}{ ANO } & \multirow{2}{*}{ MÊS } & \multirow{2}{*}{$\begin{array}{c}\text { RGM } \\
\left(\text { cal.cm }{ }^{-2} \cdot \mathrm{d}^{-1}\right)\end{array}$} & \multirow{2}{*}{$\begin{array}{c}\text { I } \\
\left(\text { h. } d^{-1}\right)\end{array}$} & \multirow{2}{*}{$\begin{array}{c}\mathrm{P} \\
(\mathrm{mm})\end{array}$} & \multirow{2}{*}{$\begin{array}{l}\text { UR } \\
(\%)\end{array}$} & \multicolumn{3}{|c|}{ Temperatura $\left({ }^{\circ} \mathrm{C}\right)$} & \multirow{2}{*}{$\begin{array}{c}\mathrm{E} \\
(\mathrm{mm})\end{array}$} \\
\hline & & & & & & Máxima & Mínima & Média & \\
\hline \multirow[t]{3}{*}{2003} & OUT & 423 & 6,3 & 89,2 & 74 & 30,0 & 16,3 & 23,1 & 5,78 \\
\hline & $\mathrm{NOV}$ & 438 & 6,0 & 168,0 & 78 & 29,5 & 17,7 & 23,6 & 5,57 \\
\hline & DEZ & 456 & 6,4 & 139,9 & 84 & 30,4 & 19,4 & 24,9 & 6,06 \\
\hline \multirow[t]{9}{*}{2004} & JAN & 371 & 4,4 & 196,4 & 83 & 29,2 & 18,7 & 23,1 & 4,95 \\
\hline & $\mathrm{FEV}$ & 422 & 6,1 & 194,0 & 86 & 29,6 & 18,4 & 24,0 & 5,93 \\
\hline & MAR & 420 & 7,1 & 79,1 & 83 & 29,5 & 17,3 & 23,4 & 5,65 \\
\hline & ABR & 355 & 6,1 & 92,3 & 83 & 29,0 & 17,1 & 23,0 & 4,14 \\
\hline & MAI & 269 & 5,0 & 105,9 & 89 & 24,3 & 12,8 & 18,6 & 2,66 \\
\hline & JUN & 258 & 5,3 & 49,7 & 85 & 24,6 & 10,7 & 17,6 & 2,41 \\
\hline & JUL & 280 & 5,6 & 78,4 & 83 & 23,8 & 11,0 & 17,4 & 2,65 \\
\hline & AGO & 399 & 8,0 & 0,0 & 65 & 27,1 & 10,1 & 18,6 & 4,30 \\
\hline & SET & 445 & 8,1 & 7,1 & 61 & 32,0 & 15,3 & 23,7 & 5,89 \\
\hline
\end{tabular}

RGM = radiação global média; $\mathrm{I}$ = insolação diária média; $\mathrm{P}$ = precipitação total; UR = Umidade relativa média do ar (determinada às 7:00 h); E = evaporação total do tanque classe A.

\subsection{Espécies estudadas}

O genótipo de milho utilizado no presente experimento foi o híbrido simples FORT (Syngenta), de ciclo precoce (890 graus-dia), com arquitetura de folhas semieretas, de coloração verde-escuro e grãos duros de coloração alaranjada. De acordo com a empresa produtora, o mesmo apresenta como características básicas, altura média de 2,39 m e altura média de inserção de espiga de 1,30 m, sendo a população considerada ideal variável entre 60 e $65.000 \mathrm{pl} \mathrm{ha}{ }^{-1}$, em áreas irrigadas. A escolha deste material genético se deveu à sua ampla adaptação às principais regiões produtoras, assim como pelas suas características agronômicas apresentadas. 
Ainda, em consórcio à cultura do milho, foram avaliadas três espécies de braquiárias, ou seja: a) B. brizantha, b) B. decumbens e c) B. ruziziensis, as quais foram semeadas em duas épocas distintas em relação à cultura do milho.

\section{3 Épocas de semeadura das braquiárias}

As braquiárias estudadas foram semeadas nas entrelinhas da cultura do milho em duas épocas, a saber:

Época 1: Semeadura das braquiárias concomitante à data de semeadura do milho;

Época 2: Semeadura das braquiárias quando o milho apresentava quatro folhas plenamente expandidas (estádio 1).

\subsection{Tratamentos estudados e delineamento experimental}

O delineamento experimental utilizado foi o de blocos ao acaso, com 7 tratamentos e quatro repetições, conforme apresentado na Tabela 4. A área total do experimento foi de 0,1 ha, sendo cada parcela constituída por quatro linhas de $7 \mathrm{~m}$ de comprimento e espaçadas de $0,7 \mathrm{~m}$.

A área útil foi constituída das duas linhas centrais, desconsiderando-se $0,5 \mathrm{~m}$ de bordadura de cada lado da parcela (Figura 1), onde foram coletados todos os dados experimentais referentes à cultura do milho. Para as avaliações relativas ao desenvolvimento das espécies de braquiárias, foram pré-estabelecidas regiões de corte perfazendo $1,0 \mathrm{~m}^{2}$, dentro da área útil mencionada, utilizando-se para tanto de um retângulo amostrador de madeira.

Os tratamentos estudados envolveram a implantação de três espécies de braquiárias na cultura do milho, em duas épocas distintas, conforme descrito na tabela 4. 
Tabela 4. Descrição dos tratamentos estudados

\begin{tabular}{cl}
\hline Tratamento & Identificação \\
\hline 1 & Semeadura exclusiva de milho (testemunha) \\
2 & Brachiaria decumbens semeada na mesma data do milho \\
3 & Brachiaria brizantha semeada na mesma data do milho \\
4 & Brachiaria ruziziensis semeada na mesma data do milho \\
5 & Brachiaria decumbens semeada com o milho apresentando quatro folhas \\
6 & Brachiaria brizantha semeada com o milho apresentando quatro folhas \\
7 & Brachiaria ruziziensis semeada com o milho apresentando quatro folhas
\end{tabular}

Os resultados obtidos foram submetidos aos modelos de análise de variância. O primeiro modelo foi correspondente a:

$$
y_{i j}=\mu+\tau_{i}+\beta_{j}+e_{i j}
$$

onde $i=1,2, \ldots, 7 ; j=1,2, \ldots, 4$

$\mu$ : é a média geral;

$\tau_{i}$ : o efeito do i-ésimo tratamento;

$\beta_{j}$ : é o efeito do j-ésimo bloco;

$e_{i j}$ : é o erro aleatório associado ao modelo, com $\varepsilon_{i j} \sim N\left(0, \sigma^{2}\right)$.

A causa da variação deste modelo acima é apresentada a seguir:

Tabela 5. Esquema de análise de variância para os dados relativos às avaliações de altura, número de folhas, índice de área foliar e diâmetro de colmo

Causas de variação

Tratamentos

Blocos

Resíduo

Total
Milho

Graus de liberdade 
O segundo modelo de análise de variância foi correspondente a:

$$
y_{i j}=\mu+\tau_{i}+e_{i j}
$$

onde $i=1,2, \ldots, 7 ; j=1,2, \ldots, 4$

$\mu$ : é a média geral;

$\tau_{i}$ : o efeito do i-ésimo tratamento;

$e_{i j}$ : é o erro aleatório associado ao modelo, com $\varepsilon_{i j} \sim N\left(0, \sigma^{2}\right)$.

A causa da variação do segundo modelo é apresentada a seguir:

Tabela 6. Esquema de análise de variância para os dados relativos às avaliações de análise foliar, componentes da produção e produtividade, para a cultura do milho e à matéria seca de raiz das braquiárias

\begin{tabular}{lcc}
\hline Causas de variação & Milho & $\begin{array}{c}\text { Braquiária (MS Raiz) } \\
\text { Graus de liberdade }\end{array}$ \\
\hline Tratamentos & 6 & 5 \\
Resíduo & 18 & 15 \\
Total & 27 & 23 \\
\hline
\end{tabular}

O terceiro e último modelo adotado foi correspondente a:

$$
y_{i j k}=\mu+\tau_{i}+\beta_{j}+(\tau \beta)_{i j}+e_{i j k}
$$

onde $i=1,2, \ldots, 7 ; j=1,2, \ldots, 3 ; k=1,2, \ldots, 4$

$\mu$ : é a média geral;

$\tau_{i}:$ o efeito do i-ésimo nível do tratamento;

$\beta_{j}$ : é o efeito do j-ésimo nível do fator avaliação;

$(\tau \beta)_{i j}$ : é o efeito da interação entre o i-ésimo nível do tratamento e o j-ésimo nível do fator avaliação; 
$e_{i j k}$ : é o erro aleatório associado ao modelo, $\operatorname{com} \varepsilon_{i j k} \sim N\left(0, \sigma^{2}\right)$.

A causa da variação deste último modelo é apresentada a seguir:

Tabela 7. Esquema de análise de variância para os dados de massa seca e verde (parte aérea de braquiária) e de supressão de plantas daninhas

\begin{tabular}{lc}
\hline Causas de variação & Graus de liberdade \\
\hline Tratamentos & 5 \\
Avaliações & 2 \\
Interação Tratamentos x Avaliações & 10 \\
Resíduo & 54 \\
Total & 71 \\
\hline
\end{tabular}

Em todos os modelos propostos para as comparações múltiplas foi utilizado o teste de Tukey a um nível de significância de 5 \%.

A análise de resíduos foi realizada em todos os modelos estimados, bem como a verificação das suposições de independência, normalidade e variância constante; comprovando, assim, a validade dos modelos apresentados.

\subsection{Condução do experimento}

\subsubsection{Preparo do solo}

O preparo do solo foi realizado na área total do ensaio e consistiu de uma aração e uma gradeação, executadas no início do mês de outubro, seguido de outra gradeação no final do mesmo mês, próximo à data de semeadura. Salienta-se que, após o preparo, o solo encontrava-se livre de plantas daninhas e em condições adequadas para a realização da semeadura. 


\subsubsection{Adubação}

Inicialmente, foi realizada a adubação de pré-semeadura, à lanço, com 60 kg $\mathrm{K}_{2} \mathrm{O}$ ha ${ }^{-1}$, oito dias antes da data de semeadura. A adubação de semeadura foi realizada, manualmente, no sulco da cultura do milho, em quantidade equivalente a $45 \mathrm{~kg} \mathrm{~N} \mathrm{ha}^{-1}$, $90 \mathrm{~kg} \mathrm{P}_{2} \mathrm{O}_{5} \mathrm{ha}^{-1}$ e $45 \mathrm{~kg} \mathrm{~K}_{2} \mathrm{O}$ ha $^{-1}$, com base nos resultados da análise de solo, na eficiência das fontes utilizadas e nos valores de exportação desses nutrientes pela cultura do milho, segundo Fancelli \& Dourado Neto (2000). A adubação de cobertura foi realizada quando o milho apresentava a quarta folha totalmente expandida (estádio 1), de forma incorporada, na entrelinha da cultura com as braquiárias, na quantidade equivalente a $100 \mathrm{~kg} \mathrm{~N} \mathrm{ha}^{-1}$, na forma de uréia.

\subsubsection{Semeadura}

A semeadura do milho foi realizada no dia 30 de outubro de 2003. O espaçamento utilizado entre linhas foi de $0,7 \mathrm{~m}$, sendo as sementes distribuídas a uma profundidade de $3 \mathrm{~cm}$ da superfície do solo e o adubo a $10 \mathrm{~cm}$, aproximadamente. Para tanto, distribuiu-se 10 sementes por metro, visando um estande final de $4,55 \mathrm{pl} \mathrm{m}^{-1}$ ou, aproximadamente, $65.000 \mathrm{pl} \mathrm{ha}^{-1}$. As forrageiras foram semeadas no meio da entrelinha de milho nas duas épocas estipuladas, manualmente, a exemplo do milho, em sulcos abertos mediante o uso de sachos. As sementes das espécies forrageiras foram distribuídas a uma profundidade de 1,0 a 2,0 cm com o equivalente a 3,0 $\mathrm{kg} \mathrm{ha}^{-1}$ de sementes puras viáveis (SPV). 


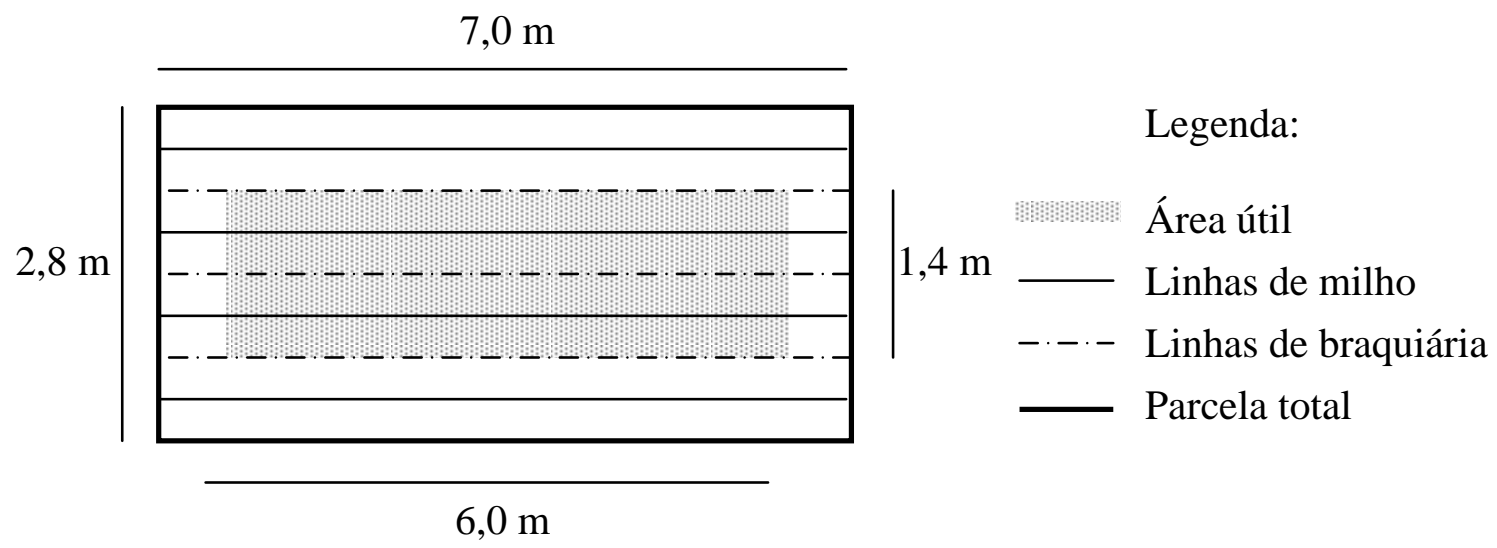

Figura 1 - Esquematização de uma parcela

\subsubsection{Tratos culturais}

Após a emergência das plântulas, quando o milho apresentava 2 folhas totalmente expandidas, realizou-se o desbaste objetivando assegurar a população equivalente a 65.000 plantas por hectare, a qual foi mantida até a colheita.

O controle das plantas daninhas foi realizado manualmente quando o milho apresentava 3 folhas totalmente expandidas (estádio V3).

Para o controle da lagarta do cartucho (Spodoptera frugiperda), foram efetuadas duas aplicações com os inseticidas Deltamethrin $\left(0,2 \mathrm{~L} \mathrm{ha}^{-1}\right)$, quando $10 \%$ das plantas apresentavam folhas “raspadas” e Lufenuron (0,3 L.ha $\left.{ }^{-1}\right), 15$ dias após, quando 20\% das plantas apresentavam-se com folhas "raspadas".

Quanto à irrigação, seu monitoramento foi baseado na manutenção da umidade do solo próxima à capacidade de campo (condição ótima), diagnosticada por tensiometria.

\subsubsection{Colheita}

A colheita do experimento foi realizada no dia 03 de Abril, após o ponto de maturidade fisiológica do milho. A referida operação foi realizada manualmente 
coletando-se todas as espigas presentes na área útil das parcelas, acompanhada da determinação do teor de água (umidade) dos grãos.

\subsection{Avaliação fitotécnica da cultura do milho}

\subsubsection{Estádios fenológicos}

A determinação do estádio fenológico do milho foi baseada na metodologia proposta por Fancelli (1986), o qual destaca que para a contagem do número de folhas, deve ser considerada como folha completamente expandida aquela que apresentar a linha de união lâmina-bainha (“colar”) facilmente visível. Ainda, o estádio é definido quando, pelo menos, $50 \%$ das plantas presentes na área apresentam a descrição característica.

\subsubsection{Altura das plantas}

A altura das plantas foi determinada no pleno florescimento do milho, medindose quatro plantas, aleatoriamente, por parcela, considerando-se para tanto a distância compreendida entre o nível do solo e o ponto de inserção da última folha. O resultado foi expresso em metros (m).

\subsubsection{Número de folhas}

A determinação do número de folhas foi realizada por ocasião do florescimento pleno, mediante a contagem do número de folhas fotossinteticamente ativas apresentando lígula visível de quatro plantas. 


\subsection{4 Índice de área foliar}

O índice de área foliar (IAF) do milho foi determinado mediante a avaliação de quatro plantas por parcela quando o milho se apresentava em pleno florescimento. A avaliação da área foliar necessária para a determinação do IAF médio das plantas amostradas foi realizada mediante a utilização do medidor eletrônico LI-3100, da LICOR Nebraska (apêndice 14).

\subsubsection{Diâmetro médio do colmo}

Para a determinação do diâmetro médio do colmo, avaliou-se o segundo internódio a partir do colo da planta, o qual foi mensurado através do uso de um paquímetro digital. A citada determinação foi efetuada por ocasião do pleno florescimento, utilizando-se as mesmas plantas empregadas na obtenção da altura média, número de folhas e índice de área foliar.

\subsubsection{Análise de tecido foliar}

A amostragem de folhas foi realizada quando o milho se apresentava no início da emissão dos estilos-estigmas, sendo a folha +4 , a partir do ápice, coletada de quatro plantas por parcela. Para a análise, utilizou-se $30 \mathrm{~cm}$ do terço médio das folhas, desconsiderando-se as respectivas nervuras. As análises químicas para a determinação das concentrações totais de nutrientes presentes no material seco foram efetuadas após digestão sulfúrica e nítrico-perclórica. A digestão sulfúrica foi utilizada na obtenção do extrato para a determinação do Nitrogênio pelo método semi-Kjedhal. A digestão nítrico-perclórica, para obtenção dos extratos para as determinações de P, K, Ca, Mg, S, $\mathrm{Cu}, \mathrm{Fe}, \mathrm{Mn}$ e Zn, foi realizada de acordo com método proposto por Sarruge \& Haag (1974). O P foi determinado por colorimetria de vanadato-molibdato, o K por fotometria de chama, o Ca, Mg, Cu, Fe, Mn e Zn por espectrofotometria de absorção atômica, o S por turbidimetria e o B por azometina. A partir das análises químicas, foram obtidas as 
concentrações totais dos macronutrientes $\mathrm{N}, \mathrm{P}, \mathrm{K}, \mathrm{Ca}, \mathrm{Mg}$ e $\mathrm{S}\left(\mathrm{g} \mathrm{kg}^{-1}\right)$ e dos micronutrientes $\mathrm{B}, \mathrm{Cu}, \mathrm{Fe}, \mathrm{Mn}$ e $\mathrm{Zn}\left(\mathrm{mg} \mathrm{kg}^{-1}\right)$.

\subsubsection{Componentes de produção}

\subsubsection{Número médio de grãos por espiga}

O número de grãos por espiga foi o resultado do produto do número médio de grãos presentes em cada fileira, pelo número médio de fileiras apresentado em cada espiga (média de 10 espigas).

\subsection{Número médio de grãos por fileira}

O número médio de grãos por fileira foi determinado em 10 espigas amostradas aleatoriamente, de cada parcela experimental, mediante simples contagem.

\subsection{Número médio de fileiras por espiga}

O número médio de fileiras de grãos na espiga foi determinado pela contagem de 10 espigas amostradas aleatoriamente de cada parcela, sendo estas as mesmas espigas utilizadas no item anterior.

\subsubsection{Massa de mil grãos}

Do total de grãos oriundos da debulha de cada parcela, retirou-se 8 amostras ao acaso, as quais foram submetidas à pesagem e ao cálculo de variância, além da determinação imediata de umidade, possibilitando estimar assim a massa de mil grãos, corrigida para 13\% de umidade, segundo metodologia apresentada nas Regras de Análises de Sementes (Brasil, 1992). 


\subsubsection{Avaliação da sanidade de grãos na espiga}

Para a avaliação da sanidade de espigas, utilizou-se uma escala diagramática (anexo A) proposta por Azevedo (1997). Para a referida análise foram utilizadas as mesmas 10 espigas amostradas e descritas no item 3.6.7.1.

\subsubsection{Produtividade}

A produtividade foi obtida a partir da massa dos grãos, oriundas da área útil das parcelas (debulhados e limpos) e expressa em $\mathrm{kg}_{\text {parcela }}{ }^{-1}$. A determinação do teor de água (umidade) foi efetuada de acordo com as Regras para Análise de Sementes (Brasil, 1992), utilizando-se o método da estufa à $105^{\circ} \mathrm{C} \pm 3^{\circ} \mathrm{C}$ por 24 horas, com três repetições para cada lote. Este método é considerado preciso e baseia-se na secagem de uma amostra de sementes, com peso conhecido e no cálculo da quantidade de água através da perda de peso da amostra. Posteriormente os valores obtidos foram corrigidos para $\mathrm{tha}^{-1}$ e para a umidade de 13\%, utilizando-se a seguinte expressão matemática:

$$
\mathrm{P}_{13 \%}=[\mathrm{PC}(1-\mathrm{U}) / 0,87]
$$

onde:

$\mathrm{P}_{13 \%}$ : produtividade de grãos a $13 \%$ de umidade, em $\mathrm{t} \mathrm{ha}{ }^{-1}$;

PC: produtividade de grãos no campo;

U: umidade do grão observada na colheita.

\subsection{Avaliações das braquiárias}

\subsubsection{Produção de massa verde e seca da parte aérea}

As plantas do gênero Brachiaria foram submetidas a três cortes a partir de uma área de $1,0 \mathrm{~m}^{2}$ pré-estabelecida. O primeiro corte, realizado no estádio de florescimento do milho, foi a $5 \mathrm{~cm}$ de altura em relação ao solo. O segundo corte, na mesma altura que o 
anterior, sendo efetuado na colheita do milho. O terceiro, foi realizado aos 60 dias após roçagem (60DAR) quando as espécies de braquiária já estavam restabelecidas, após corte, ao nível do solo, simulando um superpastejo. Após os cortes, a fitomassa resultante de cada espécie de braquiárias foi imediatamente levada ao laboratório, devidamente pesada objetivando a determinação da massa verde e, posteriormente, então submetidas à secagem em estufa à $65^{\circ} \mathrm{C}$ por 72 horas, visando à determinação da matéria seca de cada espécie.

\subsubsection{Produção de massa seca do sistema radicular}

Próximo do momento de colheita do milho foi realizada a amostragem de raízes de braquiárias utilizando-se uma sonda cilíndrica (apêndice 17) com raio de 2,25 cm $\left(15,90 \mathrm{~cm}^{2}\right)$. A referida coleta foi efetuada em todas as parcelas do experimento, posicionando-se a sonda à $10 \mathrm{~cm}$ da linha de semeadura das forrageiras, ao lado de onde se coletou a parte aérea (para a segunda análise de matéria seca). Nesse caso, foram consideradas as profundidades 0 a 20 e 20 a $40 \mathrm{~cm}$, as quais somadas resultaram na massa seca total de raízes. O material retirado da área apresentava a forma de um cilindro indeformado, composto de solo e raízes. O material coletado foi lavado e peneirado em malha de 0,25 mm, para a separação das raízes. As raízes recuperadas foram submetidas a uma pré-secagem em condições de ambiente e, posteriormente conduzidas para a secagem em estufa a uma temperatura de $70^{\circ} \mathrm{C}$ por 72 horas, para a determinação da fitomassa seca.

Embora o sistema radicular das braquiárias atinja profundidades maiores que as analisadas, assumiu-se que as raízes encontradas na profundidade de 0-40 cm seriam, responsáveis pela absorção de água e nutrientes, além de contribuírem para eventuais modificações de solo. 


\subsubsection{Supressão de plantas daninhas}

A supressão de plantas daninhas foi avaliada através de levantamentos realizados em três épocas, ou seja, aos 30, 60 e 90 dias após a roçagem (DAR). Em cada levantamento foi utilizado um quadro de $0,5 \times 1,0 \mathrm{~m}\left(0,5 \mathrm{~m}^{2}\right)$, lançado ao acaso, três vezes, dentro de cada parcela útil. A percentagem de controle foi baseada numa escala visual, comparada à biomassa verde de plantas daninhas presentes na parcela testemunha, cujo percentual de supressão foi considerado zero.

\subsection{Análise de solo após tratamentos}

Após a colheita do milho, foi realizada uma amostragem estratificada em todas as parcelas em diferentes profundidades ( 0 a 10,10 a 20 e 20 a $40 \mathrm{~cm}$ ), a fim de se avaliar os efeitos relativos a presença das braquiárias no sistema e as eventuais melhorias nas condições do solo. Os resultados mencionados são apresentados nos anexos B, C e D do presente trabalho. 


\section{RESULTADOS E DISCUSSÃO}

\subsection{Avaliação fitotécnica do milho}

\subsubsection{Estádios fenológicos}

Considerando-se a importância do acompanhamento dos estádios fenológicos do milho durante seu desenvolvimento no consórcio, foram realizadas observações diárias em todas as parcelas.

Assim, em função dos tratamentos estudados, esperava-se a ocorrência de alguma variação nos estádios fenológicos do milho, devido à eventual competição e principalmente, aos prováveis efeitos alelopáticos relacionados às braquiárias, conforme relatado por Chou (1977); Chou et al. (1989); Stanizio et al. (1991) e Rodrigues et al. (1992). Todavia, no presente experimento não foi constatado nenhuma diferença entre os tratamentos estudados, provavelmente pelas condições edafoclimáticas favoráveis reinantes no período experimental, que poderia ter contribuído para a minimização das relações de competição. As datas relativas à caracterização de cada estádio fenológico são apresentadas na tabela 8. 
Tabela 8. Estádios Fenológicos do Milho, durante a condução do experimento

\begin{tabular}{llc}
\hline \multicolumn{1}{c}{ Estádio } & \multicolumn{1}{c}{ Descrição } & Data ocorrência \\
\hline Estádio 0 (ou V0) & emergência & $04 / 11 / 2003$ \\
Estádio 1 (ou V4) & planta com quatro folhas totalmente expandidas & $19 / 11 / 2003$ \\
Estádio 2 (ou V8) & planta com oito folhas totalmente expandidas & $02 / 12 / 2003$ \\
Estádio 3 (ou V12) & planta com doze folhas totalmente expandidas & $12 / 12 / 2003$ \\
Estádio 4 (ou R1) & emissão do pendão & $02 / 01 / 2004$ \\
Estádio 5 (ou R2) & florescimento e polinização & $08 / 01 / 2004$ \\
Estádio 6 (ou R3) & grãos leitosos & $16 / 01 / 2004$ \\
Estádio 7 (ou R4) & grãos pastosos & $28 / 01 / 2004$ \\
Estádio 8 (ou R5) & grãos farináceos (formação de dentes) & $10 / 02 / 2004$ \\
Estádio 9 (ou R6) & grãos farináceos duros (dentados) & $22 / 02 / 2004$ \\
Estádio 10 (ou R7) & maturidade fisiológica & $05 / 03 / 2004$ \\
\hline
\end{tabular}

Fonte: adaptada de Fancelli (1986)

\subsubsection{Altura de plantas}

Por ocasião do pleno florescimento do milho foi realizada a determinação da altura das plantas, cujos dados podem ser observados na tabela 9.

A análise dos resultados referentes à altura das plantas não evidenciou diferença estatística entre todos os tratamentos estudados, demonstrando a inexistência da influência da presença das braquiárias, mesmo daquelas semeadas junto com o milho, no desenvolvimento do referido cereal.

Ainda, de acordo com a empresa detentora do genótipo, o híbrido FORT deveria atingir altura média de 2,39 m; todavia, no presente experimento, a altura média de planta correspondente ao tratamento testemunha foi de 2,14 m, em função da época de semeadura empregada.

A ausência de diferenças estatísticas $(\mathrm{P}<0,05)$ nesse parâmetro, para todos os tratamentos estudados, pode ser explicada pela baixa taxa de desenvolvimento inicial característica das espécies das braquiárias estudadas (Cobucci, 2003). 
Tabela 9. Valores médios de altura da planta $(\mathrm{H})$, número de folhas (NF), índice de área foliar (IAF) e diâmetro de colmo (DC) relacionados às plantas de milho em função dos tratamentos estudados

\begin{tabular}{ccccc}
\hline Tratamento & $\mathbf{H}(\mathbf{m})$ & $\mathbf{N F}$ & IAF & DC (mm) \\
\hline $\mathbf{1}$ & $2,14 \mathrm{a}$ & $14,44 \mathrm{ab}$ & $4,56 \mathrm{a}$ & $2,38 \mathrm{a}$ \\
$\mathbf{2}$ & $2,14 \mathrm{a}$ & $14,06 \mathrm{ab}$ & $4,59 \mathrm{a}$ & $2,43 \mathrm{a}$ \\
$\mathbf{3}$ & $2,10 \mathrm{a}$ & $14,13 \mathrm{ab}$ & $4,59 \mathrm{a}$ & $2,51 \mathrm{a}$ \\
$\mathbf{4}$ & $2,17 \mathrm{a}$ & $14,00 \mathrm{~b}$ & $4,53 \mathrm{a}$ & $2,45 \mathrm{a}$ \\
$\mathbf{5}$ & $2,08 \mathrm{a}$ & $14,38 \mathrm{ab}$ & $4,52 \mathrm{a}$ & $2,41 \mathrm{a}$ \\
$\mathbf{6}$ & $2,16 \mathrm{a}$ & $14,63 \mathrm{a}$ & $4,76 \mathrm{a}$ & $2,44 \mathrm{a}$ \\
$\mathbf{7}$ & $2,16 \mathrm{a}$ & $14,31 \mathrm{ab}$ & $4,67 \mathrm{a}$ & $2,45 \mathrm{a}$ \\
$\boldsymbol{C} \boldsymbol{V}$ & 5,07 & 3,96 & 4,40 & 7,26 \\
$\boldsymbol{D M S}$ & 0,12 & 0,60 & 0,47 & 0,19 \\
\hline
\end{tabular}

Médias seguidas de mesma letra na vertical não diferem entre si pelo teste de Tukey, ao nível de 5\% de probabilidade.

\subsubsection{Número de folhas}

Baseado na análise dos resultados obtidos para esse parâmetro, constatou-se a ocorrência de diferença estatística entre os tratamento 6 (B. brizantha semeada na quarta folha do milho) e 4 (B. ruziziensis semeada na mesma data do milho), conforme observado na tabela 9.

O menor número de folhas observado no tratamento 4 pode ser justificado pelo maior desenvolvimento inicial apresentado pela B. ruziziensis, em relação as demais braquiárias semeadas na mesma data do milho, conforme observado no apêndice 11 . O tratamento 6, por sua vez apresentou maior número de folhas devido ao menor desenvolvimento inicial da B. brizantha, quando semeada após a emissão da quarta folha do milho, provavelmente, devido à maior sensibilidade dessa espécie ao efeito de sombreamento imposto pelo cereal.

Ainda, foi constatado, um menor número de folha na planta de milho, nos tratamentos onde a semeadura das braquiárias ocorreu na mesma época desse cereal, apesar da não ocorrência de diferença significativa entre os tratamentos, devido a maior competição imposta às plantas nesta situação.

A redução do número de folhas pode acarretar diminuição da atividade fotossintética com conseqüente redução na produção de carboidratos e na produtividade. 
Entretanto, não foi constatado redução na produtividade do milho, provavelmente devido às condições adequadas de solo e clima, durante o período experimental, aliada à diferença reduzida do número de folhas $(0,5)$ existente entre os tratamentos contrastantes.

\subsection{4 Índice de área foliar}

O índice de área foliar (IAF) expressa a área foliar da planta em relação a área de solo ocupada pela mesma. O IAF das plantas é função de diversos fatores como: população, número de folhas fotossinteticamente ativas, tamanho das folhas, além do estado fitossanitário e nutricional das plantas.

A análise dos resultados relacionados ao IAF das plantas de milho, não evidenciou a existência de diferença significativa entre os tratamentos avaliados. Contudo, apesar do número de folhas fotossinteticamente ativas possuir correlação direta com o IAF, os tratamentos que apresentaram diferença no número de folhas não influenciaram significativamente nos resultados de IAF.

Os valores de IAF das plantas de milho relativos a todos os tratamentos estudados e apresentados na tabela 9, evidenciaram que os maiores valores para esse parâmetro foram correspondentes à semeadura da B. brizantha e da B. ruziziensis, por ocasião da $4^{\mathrm{a}}$ folha do milho, apesar de não apresentarem diferença significativa em relação aos demais.

\subsubsection{Diâmetro médio do colmo}

Os resultados médios de diâmetro de colmo obtidos no presente experimento, conforme observados na tabela 9, variaram entre 2,38 e 2,51 mm, porém não apresentaram, diferença significativa entre os tratamentos.

Neste parâmetro esperava-se encontrar diferença entre os tratamentos avaliados, uma vez que a competição por fatores de produção imposta por plantios mais densos poderia resultar em plantas com colmos mais finos e com menor ganho de matéria seca. 
Contudo, como o milho possui acentuado desenvolvimento inicial após a emissão da $4^{\mathrm{a}}$ folha e as braquiárias lento desenvolvimento inicial, tal tipo de efeito não foi concretizado. O colmo do milho, sendo uma estrutura destinada ao armazenamento de sólidos solúveis para situações emergenciais, quanto maior for o seu diâmetro, maior será sua capacidade de armazenamento de fotoassimilados, contribuindo consideravelmente para a formação de grãos.

\subsubsection{Análise de tecido foliar}

A análise foliar relativa aos diferentes tratamentos foi realizada com o intuito de verificar se a presença das braquiárias influenciaria os teores de nutrientes presentes nas plantas de milho.

Assim, a ocorrência de diferença entre os teores de nutrientes dentro desses tratamentos poderia ser atribuída a uma menor disponibilidade desses elementos no ambiente, seja pela maior extração ou mesmo por uma eventual modificação do meio, como $p H$ de rizosfera e efeito alelopático, devido a presença de uma das braquiárias.

Todavia, não foi observada nenhuma diferença significativa entre os tratamentos, indicando que as braquiárias não exerceram nenhum efeito negativo sobre o estado nutricional das plantas de milho, tanto nos teores de micronutrientes quanto de macronutrientes, pelo menos em curo prazo. O tratamento testemunha, ou seja, o milho solteiro apresentou, de forma geral, teores adequados de nutrientes, exceção feita aos teores foliares de Boro (B) e Manganês (Mn), os quais apresentaram valores abaixo dos teores críticos, propostos por Büll (1993). Para este autor, os teores críticos para a cultura do milho são: $\mathrm{N}$ (27,5 $\left.\mathrm{g} \mathrm{kg}^{-1}\right)$, P (1,9 $\left.\mathrm{g} \mathrm{kg}^{-1}\right)$, K(17,5 $\left.\mathrm{g} \mathrm{kg}^{-1}\right)$, Ca (2,3 $\left.\mathrm{g} \mathrm{kg}^{-1}\right)$, $\operatorname{Mg}\left(1,5 \mathrm{~g} \mathrm{~kg}^{-1}\right)$ e $\mathrm{S}\left(1,5 \mathrm{~g} \mathrm{~kg}^{-1}\right)$ para os macronutrientes; e $\mathrm{B}\left(15 \mathrm{mg} \mathrm{kg}^{-1}\right)$, Cu (6 mg kg-1), Fe (50 mg kg ${ }^{-1}$ ), Mn (42 mg kg-1) Zn (15 mg kg-1) para os micronutrientes, respectivamente.

É importante salientar que todos os tratamentos apresentaram teores baixos de manganês e apenas os tratamento 3 e 5 apresentaram teores baixos de boro na folha, o 
que pode ter contribuindo para o menor desenvolvimento das plantas, principalmente na variável altura.

Tabela 10. Teores foliares dos macronutrientes, Nitrogênio (N), Fósforo (P), Potássio (K), Cálcio (Ca), Magnésio (Mg) e Enxofre (S) no milho em diferentes tratamentos

\begin{tabular}{ccccccc}
\hline \multirow{2}{*}{ Tratamento } & $\mathbf{N}$ & $\mathbf{P}$ & $\mathbf{K}$ & $\mathbf{C a}$ & $\mathbf{M g}$ & $\mathbf{S}$ \\
& & \multicolumn{2}{c}{$\mathrm{gkg}^{-1}$} \\
$\mathbf{1}$ & $27,658 \mathrm{a}$ & $2,673 \mathrm{a}$ & $23,080 \mathrm{a}$ & $4,500 \mathrm{a}$ & $1,775 \mathrm{a}$ & $2,658 \mathrm{a}$ \\
$\mathbf{2}$ & $27,808 \mathrm{a}$ & $2,700 \mathrm{a}$ & $23,780 \mathrm{a}$ & $4,525 \mathrm{a}$ & $1,825 \mathrm{a}$ & $2,735 \mathrm{a}$ \\
$\mathbf{3}$ & $28,365 \mathrm{a}$ & $2,538 \mathrm{a}$ & $24,035 \mathrm{a}$ & $4,900 \mathrm{a}$ & $1,875 \mathrm{a}$ & $2,700 \mathrm{a}$ \\
$\mathbf{4}$ & $28,753 \mathrm{a}$ & $2,780 \mathrm{a}$ & $24,038 \mathrm{a}$ & $4,400 \mathrm{a}$ & $1,675 \mathrm{a}$ & $2,778 \mathrm{a}$ \\
$\mathbf{5}$ & $29,155 \mathrm{a}$ & $2,705 \mathrm{a}$ & $23,973 \mathrm{a}$ & $4,650 \mathrm{a}$ & $1,850 \mathrm{a}$ & $2,708 \mathrm{a}$ \\
$\mathbf{6}$ & $28,730 \mathrm{a}$ & $2,703 \mathrm{a}$ & $24,608 \mathrm{a}$ & $4,613 \mathrm{a}$ & $1,775 \mathrm{a}$ & $2,765 \mathrm{a}$ \\
$\mathbf{7}$ & $28,453 \mathrm{a}$ & $2,613 \mathrm{a}$ & $23,463 \mathrm{a}$ & $4,188 \mathrm{a}$ & $1,650 \mathrm{a}$ & $2,620 \mathrm{a}$ \\
$\boldsymbol{C} \boldsymbol{V}$ & 4,56 & 5,73 & 6,49 & 16,27 & 12,03 & 4,25 \\
$\boldsymbol{D M} \boldsymbol{M}$ & 2,98 & 0,35 & 3,56 & 1,70 & 0,49 & 0,26 \\
\hline \multicolumn{7}{l}{ Médias seguidas de mesma letra na vertical não diferem entre si pelo teste de Tukey, ao nível de 5\% de probabilidade. }
\end{tabular}

Tabela 11. Teores foliares dos micronutrientes, Boro (B), Cobre (Cu), Ferro (Fe), Manganês (Mn) e Zinco (Zn) na planta de milho em diferentes tratamentos

\begin{tabular}{cccccc}
\hline Tratamento & $\mathbf{B}$ & $\mathbf{C u}$ & $\begin{array}{c}\mathbf{F e} \\
\mathrm{mgkg}^{-1}\end{array}$ & $\mathbf{M n}$ & $\mathbf{Z n}$ \\
\hline $\mathbf{1}$ & $13,025 \mathrm{a}$ & $13,850 \mathrm{a}$ & $140,300 \mathrm{a}$ & $38,000 \mathrm{a}$ & $28,000 \mathrm{a}$ \\
$\mathbf{2}$ & $15,975 \mathrm{a}$ & $10,950 \mathrm{a}$ & $136,000 \mathrm{a}$ & $38,775 \mathrm{a}$ & $27,575 \mathrm{a}$ \\
$\mathbf{3}$ & $14,175 \mathrm{a}$ & $19,300 \mathrm{a}$ & $140,700 \mathrm{a}$ & $35,675 \mathrm{a}$ & $29,875 \mathrm{a}$ \\
$\mathbf{4}$ & $16,250 \mathrm{a}$ & $13,675 \mathrm{a}$ & $132,550 \mathrm{a}$ & $40,550 \mathrm{a}$ & $29,525 \mathrm{a}$ \\
$\mathbf{5}$ & $14,150 \mathrm{a}$ & $13,175 \mathrm{a}$ & $139,975 \mathrm{a}$ & $38,425 \mathrm{a}$ & $28,600 \mathrm{a}$ \\
$\mathbf{6}$ & $20,825 \mathrm{a}$ & $12,600 \mathrm{a}$ & $134,650 \mathrm{a}$ & $36,000 \mathrm{a}$ & $27,825 \mathrm{a}$ \\
$\mathbf{7}$ & $17,650 \mathrm{a}$ & $11,925 \mathrm{a}$ & $138,900 \mathrm{a}$ & $35,950 \mathrm{a}$ & $27,400 \mathrm{a}$ \\
$\boldsymbol{C} \boldsymbol{V}$ & 34,78 & 31,63 & 6,49 & 12,22 & 6,60 \\
$\mathbf{D} \boldsymbol{S}$ & 12,78 & 9,92 & 20,53 & 14,13 & 4,31 \\
\hline
\end{tabular}

Médias seguidas de mesma letra na vertical não diferem entre si pelo teste de Tukey, ao nível de 5\% de probabilidade. 


\subsubsection{Componentes de produção}

\subsubsection{Número médio de grãos}

O número de grãos por espiga é resultado da multiplicação do número médio de grãos por fileira, pelo número médio de fileiras por espiga. Diferenças no rendimento de grãos são normalmente atribuídas ao número de grãos por planta e a média da massa dos grãos formados.

Os resultados referentes ao número médio de grãos por fileiras e de fileiras por espiga são apresentados na tabela 12. A análise dos resultados não evidenciou diferença significativa entre os tratamentos, indicando que as braquiárias não exerceram efeito depressivo sobre esse parâmetro.

\subsubsection{Massa de mil grãos}

A massa individual do grão é produto da duração do período efetivo de enchimento e da taxa de crescimento do grão, que por sua vez é dependente de fatores que controlam a oferta de assimilados para o seu pleno enchimento.

Os resultados obtidos para esse parâmetro não mostraram diferenças estatísticas entre os tratamentos para esta variável, cujos valores são apresentados na tabela 12. A massa de 1000 grãos é um importante componente da produção de grãos, podendo ser afetada por qualquer tipo de estresse que a planta sofra após o florescimento (Fancelli \& Dourado Neto, 2000).

Ainda, notou-se que após a emissão da $10^{\mathrm{a}}$ folha, houve o sombreamento das braquiárias pela cultura do milho, reduzindo de maneira significativa o desenvolvimento dessas espécies. Deste modo, provavelmente, o milho não sofreu nenhuma restrição quanto ao aproveitamento de nutrientes e água objetivando a formação dos grãos, apesar da presença das braquiárias em consórcio. 
Tabela 12. Valores médios de número de fileiras (NF), número de grãos na fileira (NGF), massa de mil grãos (M 1000), nota de severidade (S) e produtividade (PROD)

\begin{tabular}{|c|c|c|c|c|c|}
\hline & $\mathbf{N F}$ & NGF & M 1000 & $\mathbf{S}$ & PROD \\
\hline Tratamento & $\begin{array}{l}\text { fileiras } \\
\text { espiga }^{-1}\end{array}$ & $\begin{array}{l}\text { grãos fileira } \\
{ }^{-} \text {espiga }^{-1}\end{array}$ & g & - & tha $^{-1}$ \\
\hline 1 & 16,25 a & 28,23 a & $350,64 \mathrm{a}$ & $2,88 \mathrm{a}$ & $9,27 \mathrm{a}$ \\
\hline 2 & 16,25 a & $29,80 \mathrm{a}$ & $347,60 \mathrm{a}$ & $2,00 \mathrm{~b}$ & 9,69 a \\
\hline 3 & 16,20 a & 30,45 a & $347,82 \mathrm{a}$ & $2,25 \mathrm{ab}$ & $9,70 \mathrm{a}$ \\
\hline 4 & $16,25 \mathrm{a}$ & 29,80 a & $352,14 \mathrm{a}$ & $2,13 \mathrm{ab}$ & 9,33 a \\
\hline 5 & 16,20 a & 30,55 a & 348,55 a & $2,63 \mathrm{ab}$ & 9,26 a \\
\hline 6 & 16,25 a & $30,40 \mathrm{a}$ & 349,87 a & $2,75 \mathrm{ab}$ & $9,50 \mathrm{a}$ \\
\hline 7 & $15,80 \mathrm{a}$ & 30,20 a & $352,25 \mathrm{a}$ & $2,38 \mathrm{ab}$ & $9,45 \mathrm{a}$ \\
\hline$C V$ & 6,94 & 12,43 & 1,47 & 14,90 & 7,36 \\
\hline DMS & 0,75 & 2,47 & 11,86 & 0,83 & 1,60 \\
\hline
\end{tabular}

\subsubsection{Avaliação da sanidade de grãos na espiga}

Esta avaliação foi realizada, devido as freqüentes chuvas ocorridas a partir do estádio 9 (grãos duros) da cultura do milho, quando os grãos estavam em fase de rápida perda de umidade, o que poderia favorecer a incidência de doenças e o atraso da colheita, por não permitir uma secagem adequada dos grãos.

Nessa variável foi constatada diferença significativa entre os tratamentos 1 (testemunha) e 2 (B. decumbens semeada na mesma data do milho), conforme apresentado na tabela 12 .

A menor incidência de grãos deteriorados nas espigas de plantas provenientes do tratamento 2 (B. decumbens semeada na mesma data do milho), em relação ao tratamento testemunha, suscita a possibilidade da interferência dessa espécie de forrageira na rizosfera do milho, favorecendo o desempenho de plantas face à ocorrência de doenças e pragas, conforme relatado por Primavesi (2002).

Ainda, partindo do pressuposto que a avaliação da sanidade está relacionada com a massa de 1000 grãos, esperava-se que o tratamento 1 apresenta-se menor massa que o tratamento 2, uma vez que grãos doentes interfeririam diretamente na massa final. Tal fato, porém, não foi observado possivelmente devido à baixa taxa de grãos ardidos 
presentes nas espigas, o que não seria suficiente para alterar a massa e, conseqüentemente, a produtividade do milho.

\subsubsection{Produtividade}

Os resultados de produtividade de milho obtidos no presente experimento, visualizados na tabela 12, ratificam a não existência de diferença significativa entre todos os tratamentos estudados. Essa constatação corrobora os resultados apresentados por Klutchcouski \& Aidar (2003); Alvim et al. (1989) e Duarte et al (1995), comprovando assim a viabilidade do consórcio entre milho e braquiárias, indiferentemente da época de semeadura utilizada.

Todavia, esses resultados discordam daqueles encontrados por Macedo \& Zimmer (1990), que verificaram a existência de efeito depressivo da B. brizantha na produtividade do milho, principalmente quando a referida espécie foi semeada em época desfavorável ao mencionado cereal. Porém, os mesmos autores relatam que o consórcio foi mais afetado pelas condições climáticas do que pela competição entre as plantas intercaladas, propriamente dita.

Assim, quanto maior a fertilidade do solo, maior será o desenvolvimento do milho, que poderá exercer maior concorrência com a planta forrageira, principalmente nos seus estádios iniciais de desenvolvimento. Como o presente trabalho foi conduzido em um solo de fertilidade alta, os efeitos de competição das braquiárias (principalmente da $B$. brizantha) sobre a produtividade do milho foram atenuados.

O vigor da plântula de milho foi maior que o das braquiárias. Por essa razão, o crescimento inicial desse cereal foi mais rápido e eficaz, provocando a retração da taxa de crescimento das espécies forrageiras. Assim, mesmo as braquiárias semeadas concomitantemente ao milho, não foi capaz de interferir na fase de diferenciação floral do cereal (V4/V6), na qual se inicia o processo de definição do potencial produtivo da espécie.

Entretanto, observou-se que os tratamentos com braquiárias semeadas na primeira época evidenciaram nítida tendência de favorecer o aumento da produtividade 
do milho, o que não era esperado; exceção feita ao tratamento 7 (B. ruziziensis semeada quando o milho apresentava 4 folhas). Essa tendência pode ser explicada pelo fato da $B$. ruziziensis apresentar um crescimento inicial mais vigoroso que as demais, o que poderia ter afetado a produtividade final da cultura.

\subsection{Avaliações referentes às braquiárias}

\subsubsection{Produção de massa verde e seca da parte aérea}

A produção de matéria seca das diferentes forrageiras indica qual das espécies de braquiária, nas respectivas épocas de semeadura, poderia apresentar maior eficiência no estabelecimento da forrageira numa determinada área.

Do ponto de vista zootécnico, a quantidade de matéria verde representa o alimento disponível para os animais. Por outro lado, para a agricultura, é importante avaliar a quantidade de massa seca produzida pelas braquiárias em consórcio, as quais promoveriam a cobertura do solo e a formação de resíduo vegetal para o sistema de Plantio Direto.

Nas Tabelas 13 e 14 estão apresentados os resultados de massa verde e seca proveniente da parte aérea das braquiárias, resultante de três avaliações. As quantidades de forragens coletadas diferiram estatisticamente nas diferentes avaliações, sendo crescente a produção de massa com o decorrer das épocas de avaliação.

Observou-se nas duas primeiras avaliações (Av1 e Av2), diferenças significativas nos valores de massa verde e seca das braquiárias de acordo com a época de semeadura, evidenciando-se o fato de que semeaduras tardias prejudicaram o desenvolvimento inicial e o acúmulo de matéria pelas braquiárias. Esse fato pode ser explicado pela eficácia da cultura do milho na competição por água, luz e nutrientes, à medida em que se atrasou a semeadura da forrageira. Tais resultados corroboram aqueles obtidos por Shelton \& Humphreys (1972) e Souza Neto (1993).

Ainda, a análise dos resultados do presente trabalho, evidenciou-se a viabilidade técnica na formação de pastagem de braquiária em associação a cultura do milho, desde 
que as forrageiras fossem implantadas na mesma ocasião da cultura. Dessa forma, o cultivo associado permitiria a produção de grãos de milho, sem o comprometimento do estabelecimento da braquiária.

Após a roçagem das braquiárias (avaliação 3), a B. decumbens apresentou desenvolvimento satisfatório nas duas épocas de semeadura (tratamentos 2 e 5), provavelmente devido a suas características morfológicas.

Quanto à massa seca média oriunda das três avaliações, dentre as braquiárias semeadas na mesma época do milho, a $B$. ruziziensis diferiu estatisticamente das $B$. brizantha e $B$. decumbens, indicando que estas se mostraram mais promissoras em relação a formação de cobertura morta.

Notou-se também, que as braquiárias reduziram consideravelmente seu desenvolvimento com o fechamento do dossel pela cultura do milho, voltando apenas a acumular fitomassa com o início do "secamento" ou senescência das folhas do milho. Após a roçagem das braquiárias os fatores que afetaram estas espécies foram anulados, diminuindo o efeito das épocas de semeadura das forrageiras no consórcio.

Tabela 13. Produção de massa verde (MV) das espécies de braquiárias (média de três avaliações)

\begin{tabular}{|c|c|c|c|c|c|c|}
\hline \multirow{2}{*}{ Tratamento } & \multicolumn{3}{|c|}{ MV (t ha $\left.{ }^{-1}\right)$} & \multirow[t]{2}{*}{ Média } & \multirow[t]{2}{*}{$C V$} & \multirow[t]{2}{*}{ DMS } \\
\hline & Av $1^{1}$ & Av 2 & Av3 & & & \\
\hline 2 & 3,86 а B & 7,28 a B & 17,42 a $A$ & $9,52 \mathrm{a}$ & 19,54 & 3,67 \\
\hline 3 & 4,14 a $C$ & 7,86 а B & 15,91 ab A & 9,31 a & 12,50 & 2,30 \\
\hline 4 & 5,51 a B & 6,89 а $\mathrm{B}$ & 10,25 bc $A$ & $7,55 \mathrm{ab}$ & 18,67 & 2,78 \\
\hline 5 & 0,28 b B & $2,58 \mathrm{~b} \mathrm{~B}$ & 14,48 abc $A$ & 5,78 bc & 48,50 & 5,54 \\
\hline 6 & 0,58 b B & $2,69 \mathrm{~b} B$ & 9,83 с A & $4,36 \mathrm{c}$ & 26,66 & 2,30 \\
\hline 7 & 0,29 b C & 2,62 b B & 8,71 с A & $3,87 \mathrm{c}$ & 19,36 & 1,48 \\
\hline Média & $2,44 \mathrm{C}$ & 4,99 B & $12,77 \mathrm{~A}$ & & & \\
\hline$C V$ & 33,66 & 10,82 & 21,19 & & & \\
\hline DMS & 1,85 & 1,21 & 6,08 & & & \\
\hline
\end{tabular}

${ }^{1} \mathrm{Av} 1=$ florescimento do milho; Av2= colheita do milho ; Av3= 60 dias após roçagem (60 DAR).

Médias seguidas da mesma letra maiúscula, na vertical, não diferem entre si pelo Teste de Tukey, ao nível de 5\% de probabilidade. Médias seguidas da mesma letra minúscula, na horizontal, não diferem entre si pelo Teste de Tukey, ao nível de 5\% de probabilidade. 
Tabela 14. Produção de massa seca (MS) das espécies de braquiárias (média de três avaliações)

\begin{tabular}{|c|c|c|c|c|c|c|}
\hline \multirow{2}{*}{ Tratamento } & \multicolumn{3}{|c|}{ MS (t ha $\left.{ }^{-1}\right)$} & \multirow[t]{2}{*}{ Média } & \multirow[t]{2}{*}{$C V$} & \multirow[t]{2}{*}{ DMS } \\
\hline & Av $1^{1}$ & Av 2 & Av3 & & & \\
\hline 2 & 0,60 a $B$ & 1,31 a $\mathrm{B}$ & 3,93 a $A$ & $1,95 \mathrm{a}$ & 18,48 & 0,71 \\
\hline 3 & 0,63 а $\mathrm{C}$ & 1,56 а B & 3,17 ab A & 1,79 а & 14,14 & 0,50 \\
\hline 4 & 0,79 а $\mathrm{B}$ & 1,06 a B & 2,22 bc $A$ & $1,36 \mathrm{~b}$ & 24,17 & 0,65 \\
\hline 5 & 0,05 b B & 0,37 b B & 3,16 ab A & 1,19 bc & 44,06 & 1,04 \\
\hline 6 & 0,09 b B & 0,35 b B & 2,10 bc $A$ & $0,84 \mathrm{~cd}$ & 27,51 & 0,46 \\
\hline 7 & 0,05 b B & 0,33 b B & 1,85 с A & $0,74 \mathrm{~d}$ & 30,68 & 0,45 \\
\hline Média & $0,37 \mathrm{C}$ & $0,88 \mathrm{~B}$ & 2,74 A & & & \\
\hline$C V$ & 37,22 & 17,79 & 20,02 & & & \\
\hline DMS & 0,31 & 330,9 & 1231,9 & & & \\
\hline
\end{tabular}

${ }^{1}$ Av1= florescimento do milho; Av2= colheita do milho ; Av3= 60 dias após roçagem (60 DAR).

Médias seguidas da mesma letra maiúscula, na vertical, não diferem entre si pelo Teste de Tukey, ao nível de 5\% de probabilidade. Médias seguidas da mesma letra minúscula, na horizontal, não diferem entre si pelo Teste de Tukey, ao nível de 5\% de probabilidade.

\subsubsection{Produção de massa seca do sistema radicular}

Os resultados referentes à massa seca de raiz nas estratificações de 0 a 20cm e 20 a $40 \mathrm{~cm}$, bem como da massa seca total de raízes, encontram-se na tabela 15 .

As coletas realizadas evidenciaram que a maior parte da massa de raiz, encontrou-se nos primeiros $20 \mathrm{~cm}$, para todas as espécies estudadas. Broch (2000), estudando raízes de $B$. decumbens, verificou que, aproximadamente, $76 \%$ da massa seca de raízes situava-se na profundidade de 0 a $20 \mathrm{~cm}$.

Na profundidade 0 - $20 \mathrm{~cm}$, o tratamento 2 (Brachiaria decumbens semeada na mesma data do milho) diferiu dos tratamentos 6 (Brachiaria brizantha semeada com o milho apresentando quatro folhas) e 7 (Brachiaria ruziziensis semeada com o milho apresentando quatro folhas); para a profundidade $20-40 \mathrm{~cm}$, os tratamentos 3 (Brachiaria decumbens semeada na mesma data do milho) e 7 diferiram estatisticamente do tratamentos 6 .

Na soma das duas estratificações, ou seja, a massa seca total de raízes, o tratamento 6 apresentou os menores valores, diferindo estatisticamente dos tratamentos 2 
e 3. Assim, ficou evidente que o atraso na época de semeadura da $B$. brizantha prejudicou o desenvolvimento de suas raízes.

Ainda, pelos resultados obtidos pode-se inferir que no tratamento 7 (Brachiaria ruziziensis semeada com o milho apresentando quatro folhas) houve menor diferença entre os valores de massa seca, nas duas estratificações.

Tabela 15. Massa seca (MSraiz) de raízes das braquiárias, em duas profundidades e total

\begin{tabular}{cccc}
\hline Tratamento & $\mathbf{0 - 2 0}$ & MSraiz $\mathbf{( t ~ h a} \mathbf{~}^{\mathbf{- 1}} \mathbf{)}$ & Total \\
\hline $\mathbf{2}$ & $1,25 \mathrm{a}$ & $\mathbf{2 1 - 4 0}$ & $1,79 \mathrm{a}$ \\
$\mathbf{3}$ & $1,19 \mathrm{ab}$ & $0,53 \mathrm{ab}$ & $1,91 \mathrm{a}$ \\
$\mathbf{4}$ & $1,06 \mathrm{ab}$ & $0,72 \mathrm{a}$ & $1,55 \mathrm{ab}$ \\
$\mathbf{5}$ & $1,18 \mathrm{ab}$ & $0,50 \mathrm{ab}$ & $1,77 \mathrm{ab}$ \\
$\mathbf{6}$ & $0,95 \mathrm{bc}$ & $0,58 \mathrm{ab}$ & $1,34 \mathrm{~b}$ \\
$\mathbf{7}$ & $0,84 \mathrm{c}$ & $0,38 \mathrm{~b}$ & $1,51 \mathrm{ab}$ \\
$\boldsymbol{C} \boldsymbol{V}$ & 12,32 & $0,67 \mathrm{a}$ & 11,69 \\
$\mathbf{D M S}$ & 0,30 & 18,27 & 0,43 \\
\hline
\end{tabular}

\subsubsection{Supressão de plantas daninhas}

A supressão de plantas daninhas pelas forrageiras, avaliada após a colheita do milho, indicou a eficiência da espécie de braquiária empregada e a respectiva época de semeadura, sobre o controle de plantas daninhas na área. Nesse caso, a área de semeadura exclusiva do milho foi considerada como padrão (supressão=zero)

Ao longo dos três levantamentos, a $B$. decumbens, indiferente à época de semeadura (tratamentos 2 e 5), resultou em maior efeito supressor de plantas daninhas em relação às demais braquiárias $(\mathrm{P}<0,05)$. A redução efetiva da presença das plantas daninhas poderia ser atribuída aos efeitos alelopáticos e as habilidades na obtenção de fatores de produção, conforme mencionado por diferentes autores.

Para as $B$. brizantha e $B$ ruziziensis, houve influência da época de semeadura sobre a supressão de plantas daninhas. Portanto, devido ao maior tempo disponível para o desenvolvimento inicial, as braquiárias semeadas concomitantemente ao milho sofreram menor interferência do sombreamento, possibilitando melhor estabelecimento 
da planta. fato este que, após a roçagem, resultou em uma rebrota mais vigorosa. Assim, o maior o desenvolvimento da parte aérea, conferiu às braquiárias semeadas na mesma data do milho maior capacidade de supressão das plantas daninhas quando comparadas àquelas semeadas na época mais tardia.

O tratamento 7 (Brachiaria ruziziensis semeada com o milho apresentando quatro folhas) apresentou menor ação de supressão de plantas daninhas, em relação aos demais, pois a referida espécie apresentou baixa taxa de recobrimento do solo, como conseqüência da sua baixa capacidade de rebrota, permitindo significativa infestação de invasoras nos espaços entre as linhas da cultura.

Tabela 16. Supressão de plantas daninhas pelas braquiárias, em três avaliações realizadas após a roçagem das braquiárias

\begin{tabular}{ccccr}
\hline \multirow{2}{*}{ Tratamento } & \multicolumn{2}{c}{ Supressão de plantas daninhas $\mathbf{( \% )} \mathbf{1}^{\mathbf{1}}$} & Média \\
& Av 1 & Av 2 & Av3 & \\
\hline $\mathbf{2}$ & $93,94 \mathrm{a}$ & $95,24 \mathrm{a}$ & $90,48 \mathrm{a}$ & $92,80 \mathrm{a}$ \\
$\mathbf{3}$ & $78,79 \mathrm{~b}$ & $77,78 \mathrm{~b}$ & $74,60 \mathrm{~b}$ & $77,32 \mathrm{~b}$ \\
$\mathbf{4}$ & $66,67 \mathrm{c}$ & $69,84 \mathrm{c}$ & $60,32 \mathrm{c}$ & $66,02 \mathrm{c}$ \\
$\mathbf{5}$ & $87,88 \mathrm{ab}$ & $87,30 \mathrm{ab}$ & $80,95 \mathrm{ab}$ & $85,57 \mathrm{ab}$ \\
$\mathbf{6}$ & $60,61 \mathrm{c}$ & $65,08 \mathrm{c}$ & $60,32 \mathrm{c}$ & $62,41 \mathrm{c}$ \\
$\mathbf{7}$ & $45,45 \mathrm{~d}$ & $50,79 \mathrm{~d}$ & $49,21 \mathrm{~d}$ & $49,01 \mathrm{~d}$ \\
$\mathrm{CV}=11,11 ; \mathrm{DMS}_{\text {trat }}=9,62 ; \mathrm{DMS}_{\text {aval }}$ & $=5,55$ & & \\
\hline
\end{tabular}

${ }^{1}$ Controle relativo, sendo tratamento 1 considerado como $0 \%$ de supressão

${ }^{2} \mathrm{Av} 1=30$ dias após roçagem (30 DAR); Av2= 60 dias após roçagem (60 DAR, que corresponde a Av3 de MV e MS de braquiárias); Av3= 90 dias após roçagem (90 DAR).

Médias seguidas da mesma letra maiúscula, na vertical, não diferem entre si pelo Teste de Tukey, ao nível de 5\% de probabilidade.

Médias seguidas da mesma letra minúscula, na horizontal, não diferem entre si pelo Teste de Tukey, ao nível de 5\% de probabilidade. 


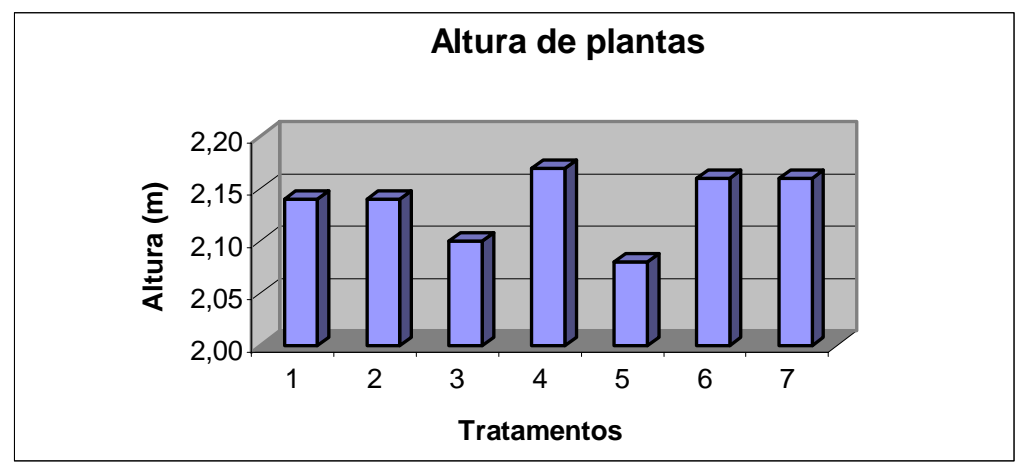

Figura 2 - Valores médios de altura de plantas de milho, em função dos tratamentos estudados

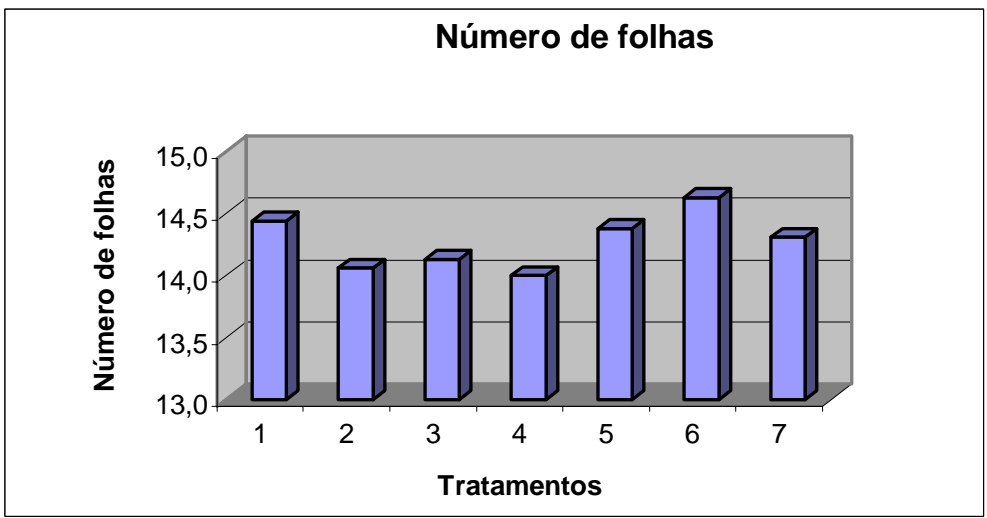

Figura 3 - Valores médios de número de folhas de plantas de milho, em função dos tratamentos estudados

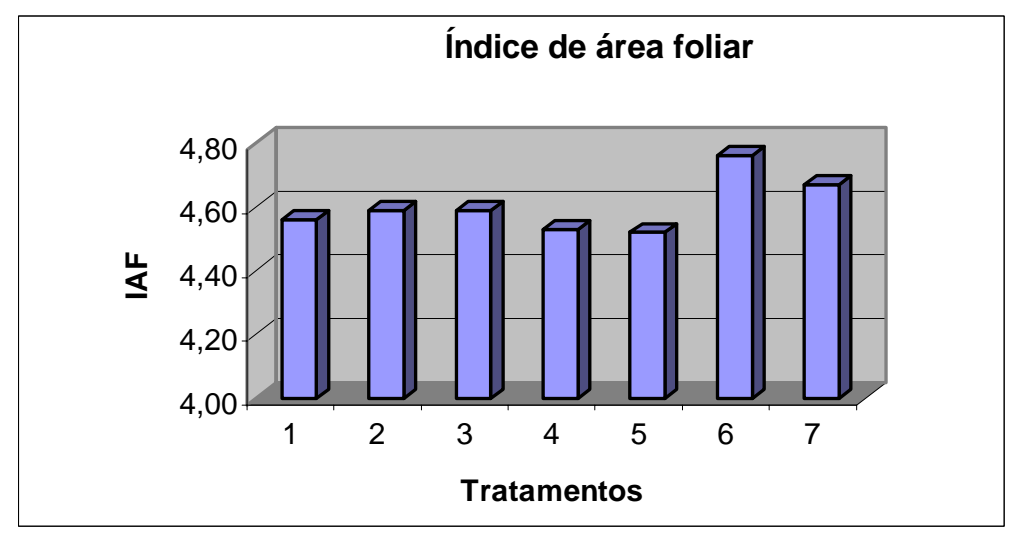

Figura 4 - Valores médios de índice de área foliar de plantas de milho, em função dos tratamentos estudados 


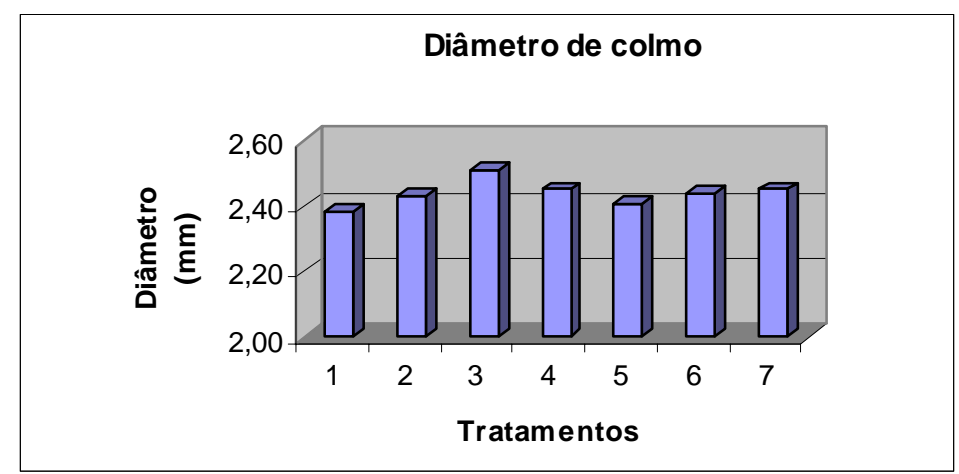

Figura 5 - Valores médios de diâmetro de colmo de plantas de milho, em função dos tratamentos estudados

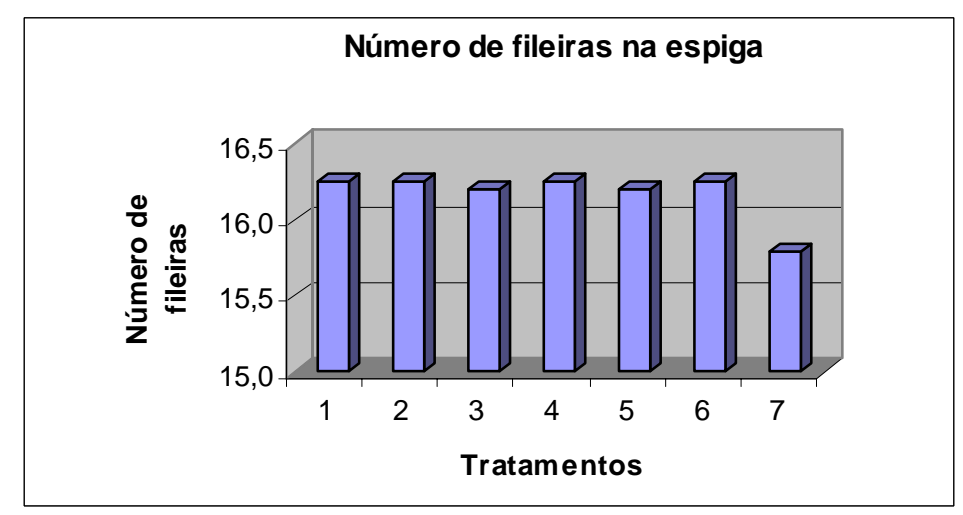

Figura 6 - Valores médios do número de fileiras presentes nas espigas de milho, em função dos tratamentos estudados

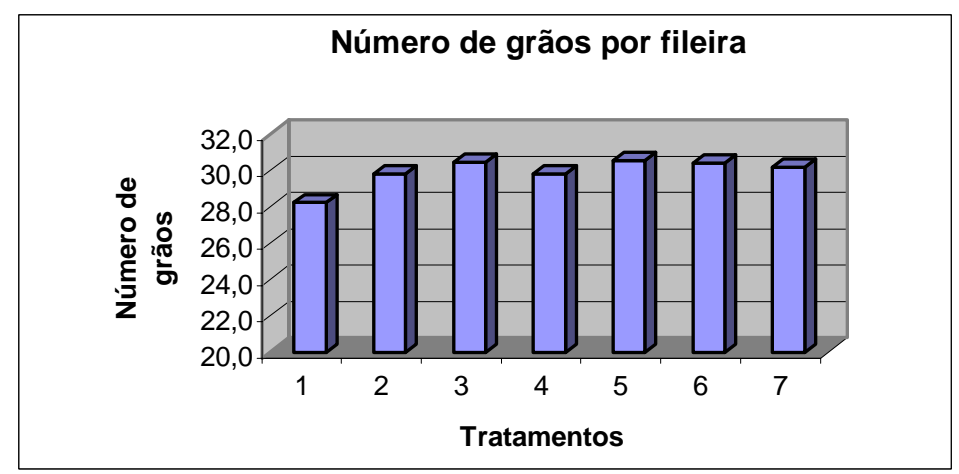

Figura 7 - Valores médios do número de grãos apresentados nas fileiras da espiga de milho 


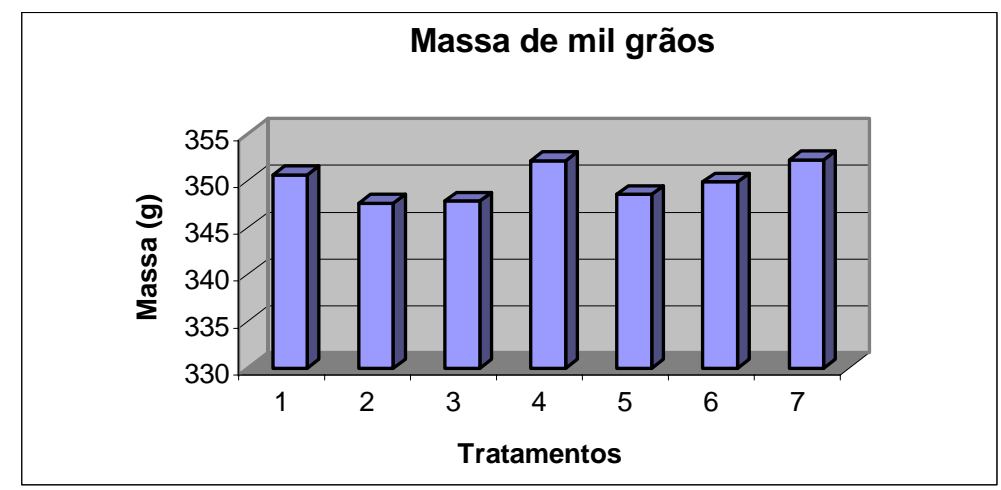

Figura 8 - Valores médios da massa de mil grãos de milho, em função dos tratamentos estudados

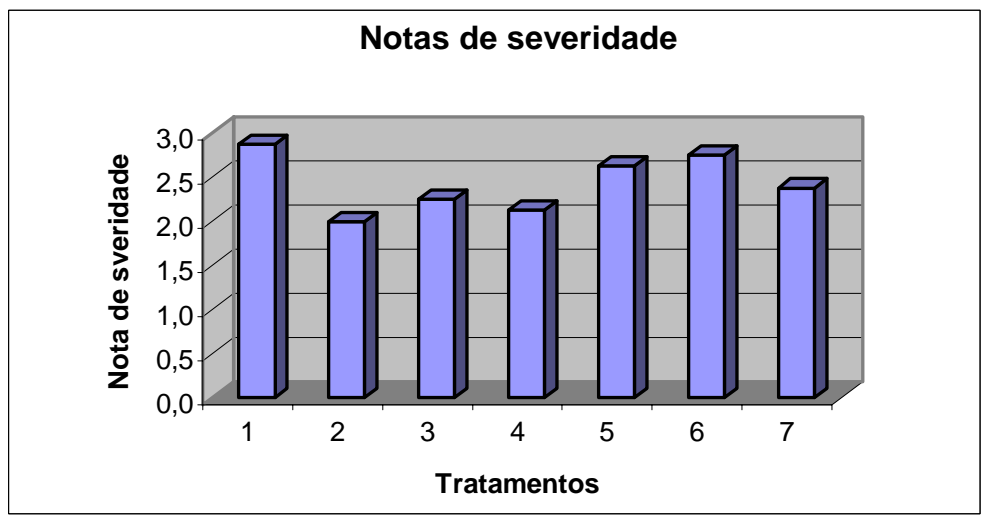

Figura 9 - Valores médios das notas de severidade de doença nos grãos presentes nas espigas de milho, em função dos tratamentos estudados

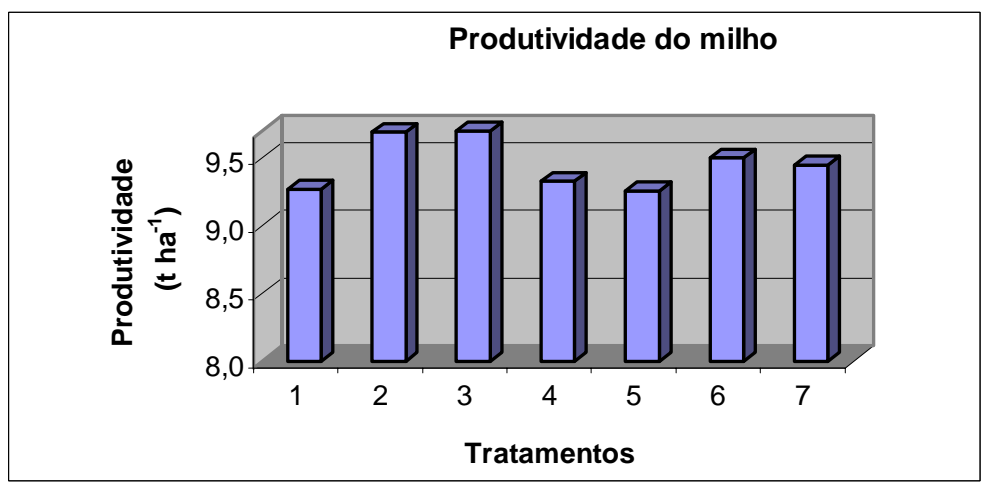

Figura 10 - Valores médios de produtividade de milho, em função dos tratamentos estudados 


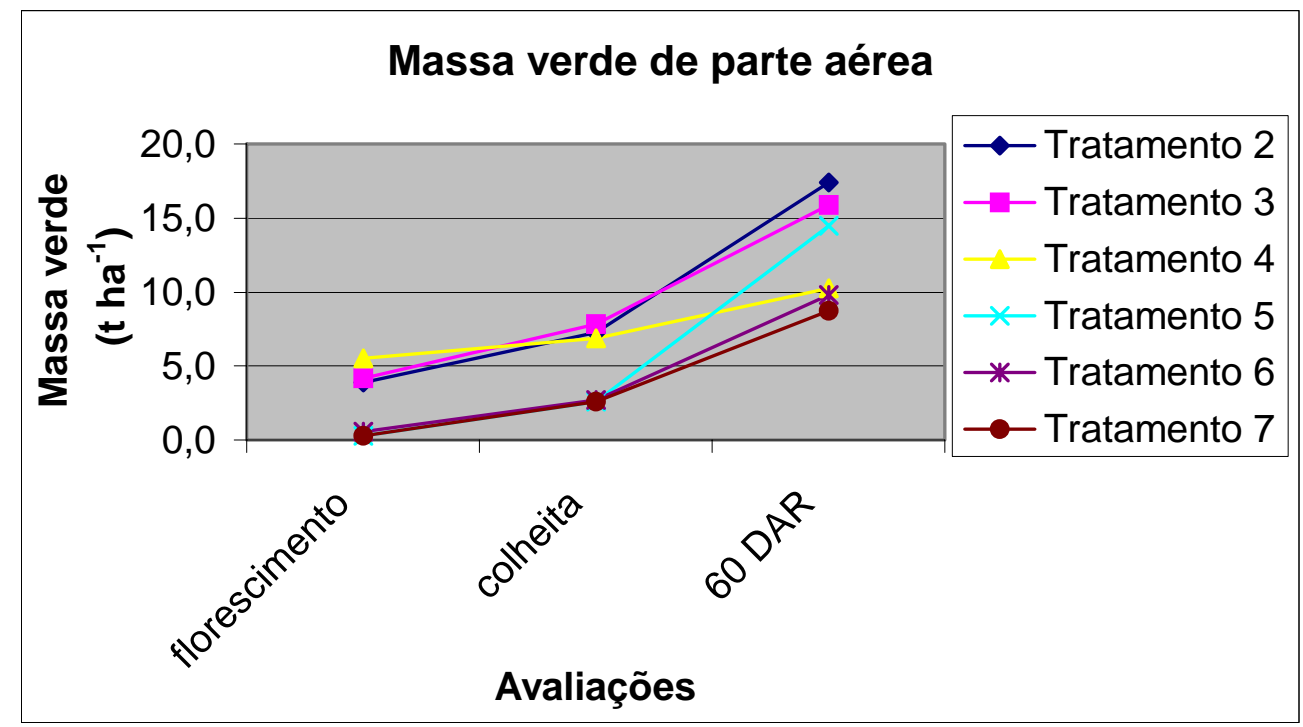

Figura 11- Produção de massa verde da parte aérea das braquiárias, realizada em três avaliações

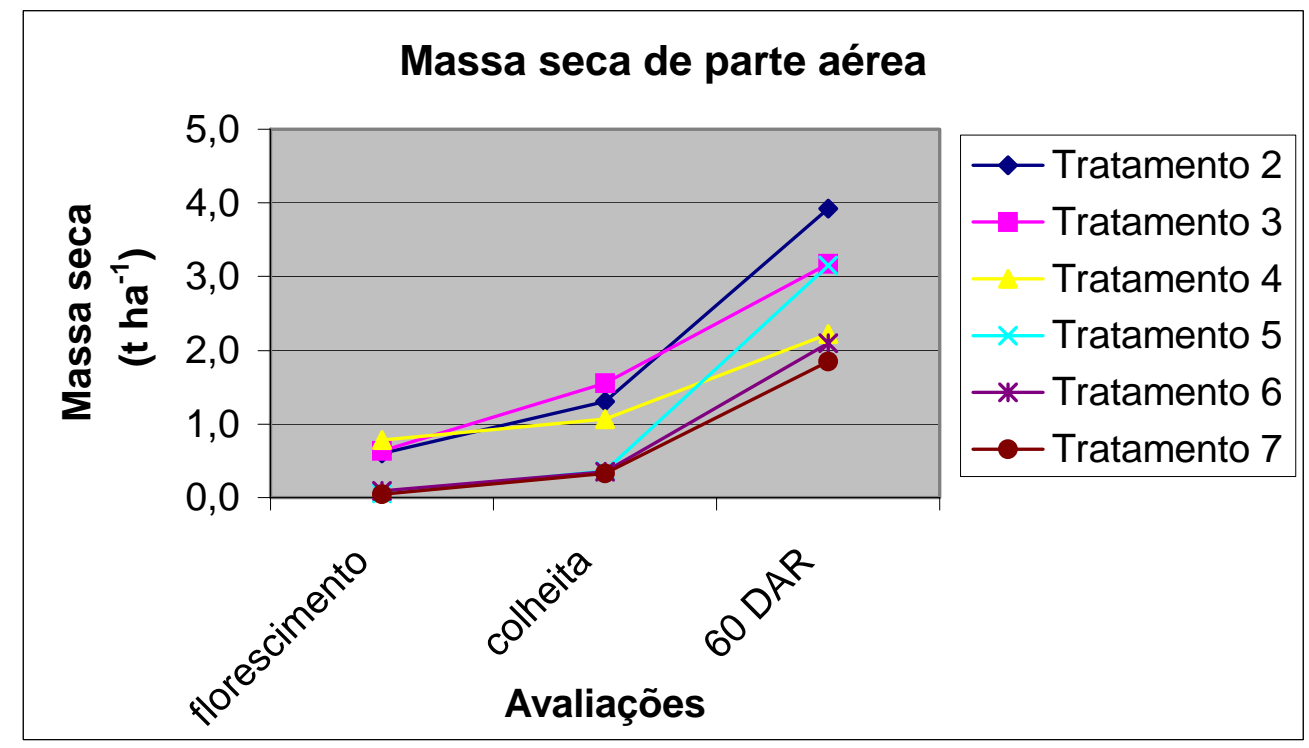

Figura 12 - Produção de massa seca da parte aérea das braquiárias, realizada em três avaliações 


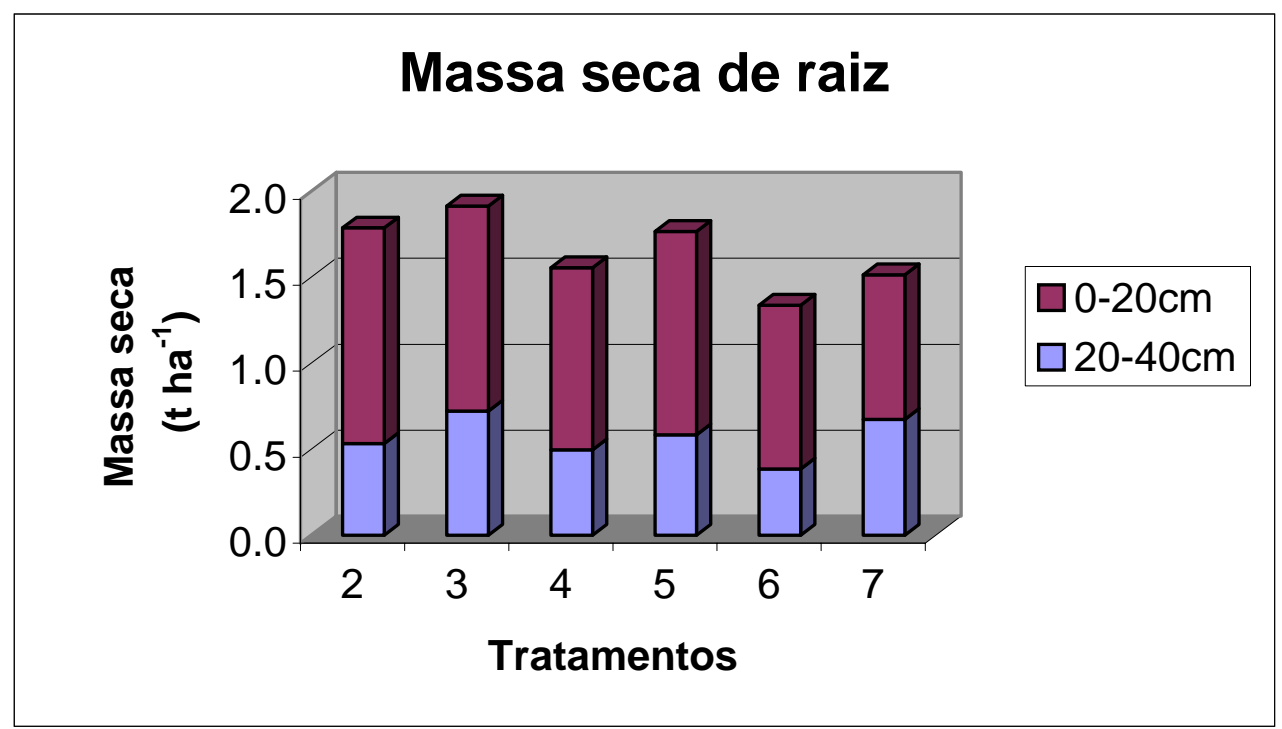

Figura 13 - . Produção de massa seca de raízes das braquiárias, em duas profundidades e total

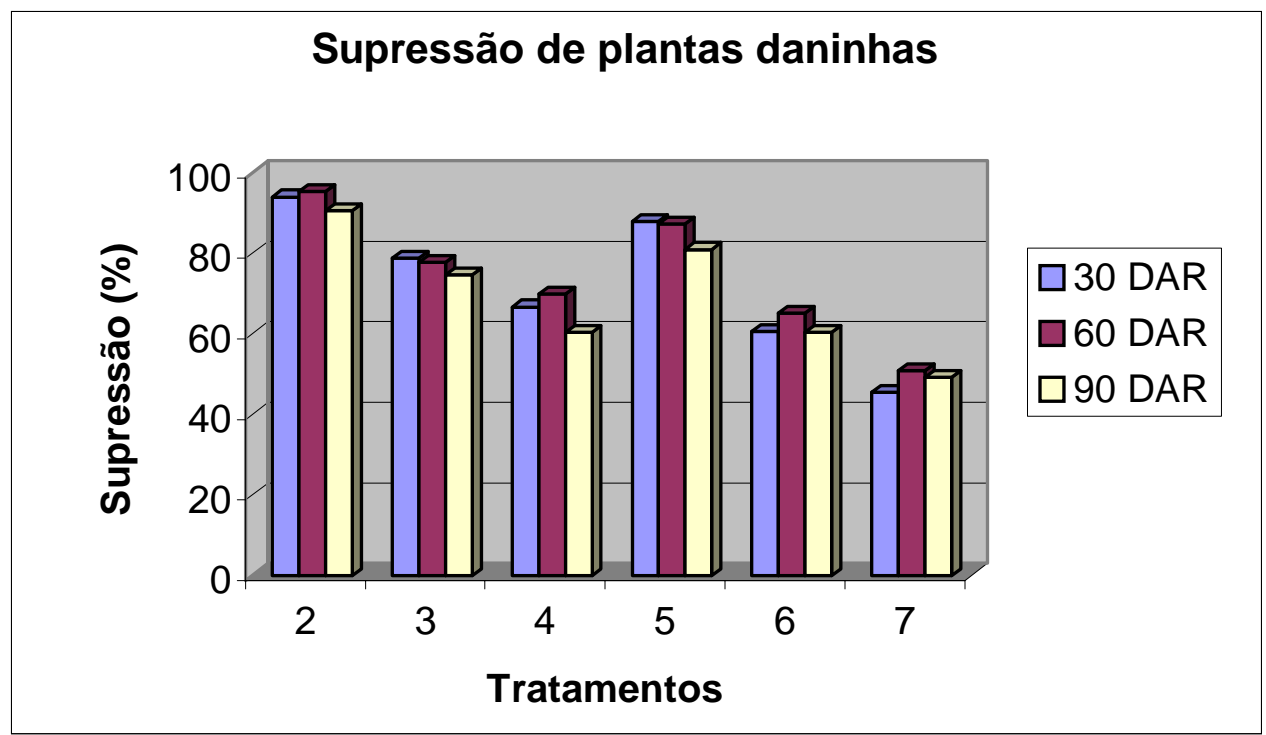

Figura 14 - Supressão de plantas daninhas pelas braquiárias, em três avaliações realizadas após a roçagem das braquiárias 


\subsection{Considerações Finais}

Com relação ao milho, os resultados obtidos evidenciaram ausência de diferença estatística entre os tratamentos para as seguintes variáveis: altura de plantas; índice de área foliar; diâmetro do colmo; número de fileiras de grãos; número de grãos por espiga; peso de mil grãos e produtividade. Todavia, o número de folhas de milho e a sanidade de espigas foram afetados pelos tratamentos estudados. Assim, o tratamento 6 (B. brizantha semeada na quarta folha do milho) propiciou maior número de folhas em plantas de milho quando comparada ao tratamento 4 (Brachiaria ruziziensis semeada na mesma data do milho). Por outro lado, a Brachiaria decumbens semeada na mesma data do milho propiciou menor taxa de grãos deteriorados na espiga em comparação ao tratamento testemunha.

O milho demonstrou ser um competidor eficaz, no sistema de consórcio, pelas suas características de rápido desenvolvimento, afetando o crescimento das braquiárias. Estas, por sua vez, não interferiram no desenvolvimento e produtividade do milho, indiferentemente à época de semeadura, provavelmente pelas condições favoráveis de solo e clima disponíveis ao longo do ensaio.

Sob o ponto de vista de produção de forragem todas as espécies de braquiárias semeadas na mesma data do milho, apresentaram resultados semelhantes. Porém, com relação ao sistema radicular, apenas a $B$. decumbens (indiferente à época de semeadura) evidenciou maior desenvolvimento radicular. Assim o atraso na semeadura das braquiárias afetou seu pleno estabelecimento. Todavia a B. decumbens e a B. brizantha, devido as suas características morfológicas apresentaram resposta satisfatória a roçagem, proporcionando grande quantidade de fitomassa, após esta operação; além de auxiliarem significativamente no controle de plantas daninhas, provavelmente por efeitos alelopáticos. 


\section{CONCLUSÃO}

A análise e a interpretação dos resultados relativos ao presente trabalho permitiram concluir que a presença das braquiárias, indiferentemente à época de semeadura, não afeta a produtividade do milho, demonstrando assim a viabilidade técnica de sistemas consorciados de produção. Entretanto, a presença do milho influencia negativamente o acúmulo de fitomassa das braquiárias, principalmente, quando estas são semeadas quando o milho apresenta quatro folhas.

Para a formação de pastagens, as forrageiras estudadas apresentam melhor desempenho e produtividade quando implantadas na mesma data da cultura do milho.

Dentre as braquiárias, destaca-se a $B$. decumbens pela quantidade de forragem produzida, bem como pelo efeito supressor de plantas daninhas. Entretanto, para a produção de forragem a $B$. brizantha apresenta resultados semelhantes a $B$. decumbens. 
ANEXOS 
ANEXO A. Escala diagramática utilizada para a avaliação da sanidade de espiga (Azevedo, 1997)
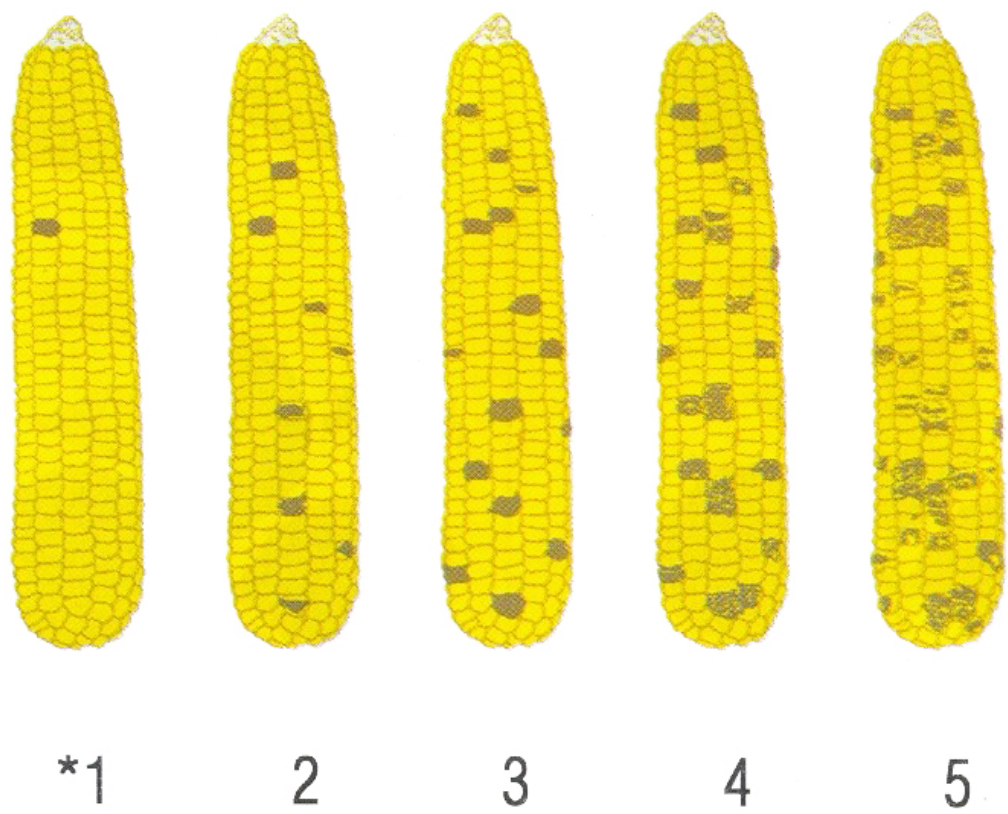

2

3

4

5

$1 \%$

$10 \%$

$20 \%$

$30 \%$

$50 \%$

${ }^{*}$ Notas de severidade 
Anexo B. Resultados da Análise química de solo na profundidade de 0-10 cm, após a colheita do milho

\begin{tabular}{|c|c|c|c|c|c|c|c|c|c|c|c|c|c|}
\hline Amostra & $\begin{array}{c}\mathrm{pH} \\
\mathrm{CaCl}_{2}\end{array}$ & $\begin{array}{c}\text { M.O } \\
\text { g.dm }^{-3}\end{array}$ & $\begin{array}{l}\mathbf{P} \\
\mathbf{m}\end{array}$ & $n^{-3}$ & $\mathbf{K}$ & Ca & Mg & $\begin{array}{c}\text { Al } \\
\text { mmol }_{\mathbf{c}} \mathrm{dm}^{-3}\end{array}$ & $\mathbf{H}+\mathbf{A l}$ & SB & $\mathbf{T}$ & $\mathbf{V}$ & $\mathbf{m}$ \\
\hline 1 & 5,0 & 24,0 & 38,0 & 12,0 & 5,5 & 43,0 & 14,0 & 1,0 & 31,0 & 62,5 & 93,5 & 67,0 & 0,0 \\
\hline 2 & 5,0 & 22,0 & 34,0 & 16,0 & 5,5 & 40,0 & 11,0 & 1,0 & 31,0 & 56,5 & 87,5 & 65,0 & 0,0 \\
\hline 3 & 5,0 & 21,0 & 62,0 & 16,0 & 5,5 & 44,0 & 13,0 & 1,0 & 31,0 & 62,5 & 93,5 & 67,0 & 0,0 \\
\hline 4 & 4,5 & 22,0 & 53,0 & 25,0 & 5,5 & 36,0 & 9,0 & 3,0 & 42,0 & 50,5 & 92,5 & 55,0 & 6,0 \\
\hline 5 & 5,0 & 20,0 & 30,0 & 12,0 & 5,4 & 33,0 & 10,0 & 1,0 & 31,0 & 48,4 & 79,4 & 61,0 & 0,0 \\
\hline 6 & 4,9 & 23,0 & 55,0 & 11,0 & 3,8 & 49,0 & 14,0 & 0,0 & 34,0 & 66,8 & 100,8 & 66,0 & 0,0 \\
\hline 7 & 4,9 & 26,0 & 49,0 & 13,0 & 5,9 & 41,0 & 12,0 & 2,0 & 34,0 & 58,9 & 92,9 & 63,0 & 3,0 \\
\hline
\end{tabular}


Anexo B. Resultados da Análise química de solo na profundidade de 0-10cm, após a colheita do milho (continuação)

\begin{tabular}{cccccc}
\hline Amostra & $\mathbf{B}$ & $\mathbf{C u}$ & $\begin{array}{c}\mathbf{F e} \\
\mathbf{m g . d m}^{-3}\end{array}$ & $\mathbf{M n}$ & $\mathbf{Z n}$ \\
\hline $\mathbf{1}$ & 0,27 & 4,50 & 21,00 & 31,00 & 2,50 \\
$\mathbf{2}$ & 0,30 & 5,10 & 28,00 & 31,80 & 2,50 \\
$\mathbf{3}$ & 0,32 & 4,50 & 29,00 & 24,20 & 1,90 \\
$\mathbf{4}$ & 0,36 & 5,10 & 28,00 & 39,30 & 1,60 \\
$\mathbf{5}$ & 0,35 & 3,80 & 23,00 & 27,60 & 3,00 \\
$\mathbf{6}$ & 0,31 & 4,00 & 24,00 & 30,80 & 1,40 \\
$\mathbf{7}$ & 0,37 & 4,80 & 22,00 & 30,30 & 2,00 \\
\hline
\end{tabular}


Anexo C. Resultados da Análise química de solo na profundidade de 10-20 cm, após a colheita do milho

\begin{tabular}{|c|c|c|c|c|c|c|c|c|c|c|c|c|c|}
\hline Amostra & $\begin{array}{c}\mathbf{p H} \\
\mathrm{CaCl}_{2}\end{array}$ & $\begin{array}{c}\text { M.O } \\
\text { g.dm }^{-3}\end{array}$ & $\begin{array}{l}\mathbf{P} \\
\mathbf{m}\end{array}$ & $n^{-3}$ & $\mathbf{K}$ & Ca & Mg & $\begin{array}{c}\text { Al } \\
\mathbf{m m o l}_{\mathrm{c}} \mathrm{dm}\end{array}$ & $\mathbf{H}+\mathbf{A l}$ & SB & $\mathbf{T}$ & $\mathbf{V}$ & $\mathbf{m}$ \\
\hline 1 & 5,0 & 22,0 & 29,0 & 20,0 & 4,7 & 46,0 & 14,0 & 0,0 & 31,0 & 64,7 & 95,7 & 68,0 & 0,0 \\
\hline 2 & 4,9 & 25,0 & 26,0 & 27,0 & 5,0 & 38,0 & 11,0 & 1,0 & 34,0 & 54,0 & 88,0 & 61,0 & 2,0 \\
\hline 3 & 4,7 & 23,0 & 33,0 & 43,0 & 5,4 & 39,0 & 11,0 & 2,0 & 38,0 & 55,4 & 93,4 & 59,0 & 3,0 \\
\hline 4 & 4,8 & 23,0 & 17,0 & 21,0 & 3,3 & 39,0 & 10,0 & 1,0 & 34,0 & 52,3 & 86,3 & 61,0 & 2,0 \\
\hline 5 & 4,9 & 24,0 & 29,0 & 32,0 & 4,8 & 42,0 & 11,0 & 1,0 & 34,0 & 57,8 & 91,8 & 63,0 & 2,0 \\
\hline 6 & 4,9 & 22,0 & 18,0 & 16,0 & 3,6 & 40,0 & 12,0 & 1,0 & 31,0 & 55,6 & 86,6 & 64,0 & 2,0 \\
\hline 7 & 4,8 & 24,0 & 27,0 & 30,0 & 4,1 & 41,0 & 11,0 & 1,0 & 34,0 & 56,1 & 90,1 & 62,0 & 2,0 \\
\hline
\end{tabular}


Anexo C. Resultados da Análise química de solo na profundidade de 10-20cm, após a colheita do milho (continuação)

\begin{tabular}{cccccc}
\hline Amostra & $\mathbf{B}$ & $\mathbf{C u}$ & $\begin{array}{c}\mathbf{F e} \\
\mathbf{m g . d m}^{-3}\end{array}$ & $\mathbf{M n}$ & $\mathbf{Z n}$ \\
\hline $\mathbf{1}$ & 0,30 & 5,10 & 29,00 & 43,70 & 1,80 \\
$\mathbf{2}$ & 0,33 & 3,90 & 31,00 & 32,30 & 1,50 \\
$\mathbf{3}$ & 0,32 & 3,70 & 27,00 & 36,30 & 1,60 \\
$\mathbf{4}$ & 0,38 & 4,50 & 21,00 & 35,40 & 1,10 \\
$\mathbf{5}$ & 0,27 & 4,80 & 24,00 & 24,30 & 2,30 \\
$\mathbf{6}$ & 0,30 & 4,60 & 24,00 & 29,90 & 1,70 \\
$\mathbf{7}$ & 0,36 & 4,70 & 23,00 & 31,80 & 2,10 \\
\hline
\end{tabular}


Anexo D. Resultados da Análise química de solo na profundidade de 20-40 cm, após a colheita do milho

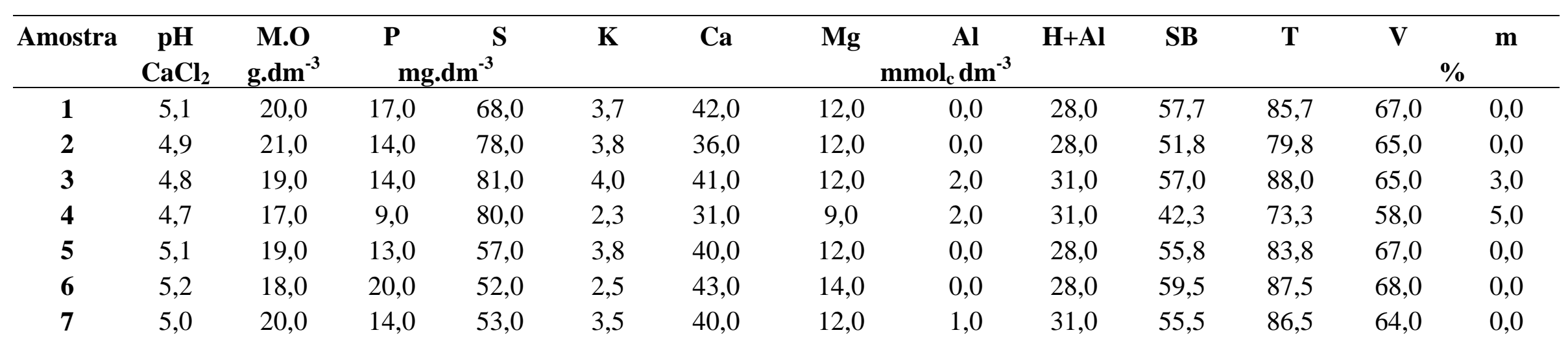


Anexo D. Resultados da Análise química de solo na profundidade de 20-40cm, após a colheita do milho (continuação)

\begin{tabular}{cccccc}
\hline Amostra & $\mathbf{B}$ & $\mathbf{C u}$ & $\begin{array}{c}\mathbf{F e} \\
\mathbf{m g . d m}^{-3}\end{array}$ & $\mathbf{M n}$ & $\mathbf{Z n}$ \\
\hline $\mathbf{1}$ & 0,21 & 2,90 & 11,00 & 16,00 & 0,90 \\
$\mathbf{2}$ & 0,27 & 3,10 & 17,00 & 16,80 & 1,00 \\
$\mathbf{3}$ & 0,21 & 3,00 & 14,00 & 16,70 & 0,80 \\
$\mathbf{4}$ & 0,23 & 2,00 & 9,00 & 17,00 & 0,60 \\
$\mathbf{5}$ & 0,26 & 2,50 & 12,00 & 16,20 & 0,60 \\
$\mathbf{6}$ & 0,19 & 2,20 & 11,00 & 9,70 & 0,60 \\
$\mathbf{7}$ & 0,26 & 3,30 & 14,00 & 18,40 & 0,80 \\
\hline
\end{tabular}




\section{REFERÊNCIA BIBLIOGRÁFICA}

ALCÂNTARA, P. B.; BUFARAH, G. Plantas forrageiras: gramíneas e leguminosas. São Paulo: Nobel, 1988. 150 p.

ALCÂNTARA, P.B.; PEDRO JUNIOR., M.J.;DONZELLI, P.L. Zoneamento edafoclimático de plantas forrageiras. In: SIMPÓSIO SOBRE ECOSSISTEMAS DE PASTAGENS, 2., Jaboticabal, 1993. Anais. Jaboticabal: FUNEP, 1993. p.1-16.

ALMEIDA, F. S. Alelopatia e as plantas. Londrina: IAPAR, 1988, 60 p. (IAPAR, Circular Técnica, 53).

ALVIM, M.J.; BOTREL,M. de A.; SALVATI, J.A. Métodos de estabelecimento de Brachiaria decumbens em associação à cultura do milho. Revista da Sociedade Brasileira de Zootecnia. v.18,n.5,p. 417- 425, 1989.

ALVIM, M.J.; BOTREL,M. de A.; VERNEQUE, R. da S.; SALVATI, J.A. Aplicação de Nitrogênio em acessos de Brachiaria. 1. Efeito sobre a produção de Matéria Seca. Pasturas Tropicales, v.12,n.2,p.2-6, 1990.

AZEVEDO, L.A.S. Manual de quantificação de doenças de plantas. São Paulo: s. ed, 1997. 114p. 
BAUMANN, D.T.; BASTIAANS, L.; KROPFF, M. J. Effects of intercropping on growth and reproductive capacity of late-emerging Senecio vulgaris, with special reference to competition for light. Annals of Botany, v.87, p.209-217, 2001.

BEGNA, S.H. Morphology and yield response to weed pressure by corn hybrids differing in canopy architeture. European Journal of Agronomy,. v.14, n. 4, p. 293302, 2001.

BLANCO, H.G. Catálogo de espécies de mato infestantes de áreas cultivadas no Brasil. Campinas: CECORT/CATI, 1978. 90 p.

BODDEY, R.M.; RAO, I.M.; THOMAS, R.J. Nutrient cycling and environmental impact of Brachiaria pastures. In: MILES, J.W.; MAASS, B.L.; VALLE, C.B. do (Ed.). Brachiaria: biology, agronomy and improvement. Cali: CIAT; Brasília: EMBRAPA - CNPGC, 1996. p. 72-86.

BOGDAN, A.V. Tropical pastures and fodder plants. London: Longman. 1977. 475p.

BOTREL, M.A.; ALVIM, M.J.; XAVIER, D.F. Avaliação de gramíneas forrageiras na região sul de Minas Gerais. Pesquisa Agropecuária Brasileira, v.34, n.4,. p.683689, 1999.

BRASIL. Ministério da Agricultura e Reforma Agrária. Regras para análise de sementes. Brasília: Ministério da Agricultura e Reforma Agrária, Secretaria Nacional de defesa agropecuária, 1992. 365p.

BROCH, D. L. Integração agricultura-pecuária no Centro Oeste do Brasil. In: ENCONTRO REGIONAL DE PLANTIO DIRETO NO CERRADO, 4., Uberlândia, 1999. Plantio Direto na integração lavoura pecuária. Uberlândia: Universidade Federal de Uberlândia, 2000. p. 53-60. 
CARVALHO, M.M. de ; CRUZ FILHO, A.B. da. Estabelecimento de pastagens. Coronel Pacheco, MG: EMBRAPA-CNPGL, 1985. 46 p. (EMBRAPA- CNPGL, Circular Técnica, 26).

CARVALHO, S.I.C. de; VILELA, L.; SPAIN, J.M.; KARIA, C.T. Recuperação de pastagens degradadas de Brachiaria decumbens cv. Basilisk na região dos Cerrados. Pasturas Tropicales, v.12, n. 2, p. 24-28, 1990.

CHASTAIN, T.G.; GRABE, D.F. Spring establishment of orchad grass weed crops with cereal companion crops. Crop Science, v. 29, p. 466-471, 1989.

CHOU, C. H. Phytotoxic substances in twelve subtropical grasses. I. Addditional evidences of phytotoxicity in the aqueous fractions of grass extracts. Botanical Bulletin of Academia Sinica, v.18,p.131-41, 1977.

CHOU, C. H.; CHANG, S. J.; CHENG, C. M.; WANG, Y. C.; HSU, F.H.; DEN, W. H. The selective allelophatic interaction of pasture-forest intercropping in Taiwan. II. Interaction between kikuyu grass and three hardwood plants. Plant and soil, v..116,p.207-215, 1989.

COBUCCI, T. Sistema Santa Fé: integração agricultura pecuária. In: DOURADO NETO, D.; FANCELLI, A. L. Feijão irrigado - tecnologia e produtividade. Piracicaba: Departamento de Produção Vegetal, ESALQ, USP, 2003. 165p.

COBUCCI, T.; PORTELA, C.M. de O. Manejo de herbicidas no sistema Santa Fé e na Braquiária como fonte de cobertura morta. In: KLUTHCOUSKI, J.; STONE, L.F.; AIDAR, H. (Ed.). Integração lavoura-pecuária. Santo Antônio de Goiás: Embrapa Arroz e Feijão, 2003. p. 445-458. 
CORAZZA, E.J. Biodisponibilidade do íon fosfato em solos sob pastagens cultivadas na região do cerrado. Piracicaba, 2002. 127 p. Tese (Doutorado) -Escola Superior de Agricultura “Luiz de Queiroz”, Universidade de São Paulo.

CORREAA, L. A.; HAAG, H.P. Níveis críticos de fósforo para o estabelecimento de gramíneas forrageiras em latossolo vermelho-amarelo, álico. I: ensaio em casa de vegetação. Scientia Agricola. v.50. n.1. p.99-108. 1993 a.

CORRÊA, L. A.; HAAG, H.P. Níveis críticos de fósforo para o estabelecimento de gramíneas forrageiras em latossolo vermelho-amarelo, álico. II: experimento de campo. Scientia Agricola. v.50. n.1. p.109-116. 1993 b.

CRUZ FILHO, A.B. da. Práticas agronômicas para o estabelecimento de pastagens. Coronel Pacheco: EMBRAPA, CNPGL, 1990. 25 p. (EMBRAPA.CNPGL. Documentos, (37).

DIAS FILHO, M.B. Growth and biomass allocation of the $\mathrm{C}_{4}$ grasses Brachiaria brizantha and Brachiaria humidicola under shade. Pesquisa Agropecuária Brasileira, v. 35, n.12, p.2335-2341, 2000.

DIAS FILHO, M.B. Photosynthetic light response of $\mathrm{C}_{4}$ grasses Brachiaria brizantha and Brachiaria humidicola under shade. Scientia Agricola, v. 59, n. 1, p. 65-68, 2002.

DUARTE, J.M.; PEZO, D.A.; ARZE,J. Crescimiento de tres gramíneas forrajeras establecidas en cultivo intercalado com maiz (Zea mays L.) o Vigna (Vigna unguiculata (l.) Walp). Pasturas Ttropicales, v.16,n.1,p.8-14, 1994. 
DUARTE, J.M.; PÉREZ, H.E.; PEZO, D.A.; ARZE,J.; ROMERO, F.; ARGEL P.J. Producción de maíz (Zea mays L.), soya (Glycine max L.) y caupí (Vigna unguiculata (L.) Walp) sembreados en associción con gramíneas en el trópico húmedo. Pasturas tropicales, v.17,n.2,p.12-19, 1995.

EMPRESA BRASILEIRA DE PESQUISA AGROPECUÁRIA. Centro Nacional de Pesquisa de Gado de Leite. Algumas considerações sobre gramíneas e leguminosas forrageiras. Coronel Pacheco: EMBRAPA, 1983. 59p.

FANCELLI, A.L. Plantas alimentícias: guia para aula estudos e discussão. Piracicaba: ESALQ, Departamento de Agricultura, 1986. 131 p.

FANCELLI, A.L. Tecnologia de produção do milho para alta produtividade. Piracicaba: ESALQ, Departamento de Agricultura, 1994. 223 p.

FANCELli, A.L.; DOURADO-NETO, D. Produção de milho. Guaíba: Agropecuária, 2000. 360p.

FERREIRA, P.V. Experimentos com consorciação de culturas. In: Estatística experimental aplicada à agronomia, s. 1.: s. ed.,2000. p. 361-386.

FLECK, N. G. Princípios do controle de plantas daninhas. Porto Alegre: UFRGS, 1992. 70p.

FLECK, N.G.; RIZZARDI, M. A.; AGOSTINETTO, D. et al. Interferência de picão preto e guanxuma com a soja: efeitos da densidade de planta e época relativa de emergência. Ciência Rural, v.34, n.1, p.41-48, 2004. 
GHISI, O. M. A. A.; PEDREIRA, J. V. S. Características agronômicas das principais Brachiaria spp. In; ENCONTRO SOBRE CAPINS DO GÊNERO BRACHIARIA, 1., Nova Odessa, 1986. Anais. Nova Odessa: Instituto de Zootecnia, 1987. p.19-57.

HALE, M.G.; ORCUTT, D.M. The physiology of plant under stress. New York, John Willey, 1987, 206 p.

HOLT, J. Plant response to light: a potential tool for weed management. Weed Science, v.43, p. 474-482, 1995.

JEFFERIES. R. A. Cultivar responses to water stress in potato; effects of shoot and roots. New Phytologist, v. 123, p.491-498, 1993.

KEATING, B.; CARBERRY, P. S. Resource capture and use in intercropping: solar radiation. Fields Crops Research, v. 34, p. 273-301, 1993.

KLUTHCOUSKI, J.; AIDAR, H. Implantação, condução e resultados obtidos com o sistema Santa Fé. In: KLUTHCOUSKI, J.; STONE, L.F.; AIDAR, H. (Ed.) Integração Lavoura-Pecuária. Santo Antônio de Goiás: Embrapa Arroz e Feijão, 2003. p. 407-441.

KLUTHCOUSKI, J.; COBUCCI, T.; AIDAR, H. et al. Sistema Santa Fé - Tecnologia Embrapa: Integração lavoura pecuária pelo consórcio de culturas anuais com forrageiras, em áreas de lavoura, nos sistemas direto e convencional. Santo Antônio de Goiás: Embrapa Arroz e feijão, 2000. 28 p. (Embrapa Arroz e Feijão. Circular Técnica, 38). 
LOBATO, E.; KORNELIUS, E.; SANZONOWICZ, C. Adubação fosfatada em pastagens. In: SIMPÓSIO SOBRE ADUBAÇÃO E CALAGEM DE PASTAGENS, 1., Nova Odessa, 1985. Calagem e adubação de pastagens. Piracicaba, SP: POTAFOS, $1986 . \quad$ p. $145-174$

LORENS, G. F.; BENNETT, J. M.; LOGGALE, L. B. Differences in drought resistance between two corn hybrids. I.Water relation and root lenght density. Agronomy Journal, v. 79, p.802-807, 1987.

LORENZI, H. Plantas daninhas no Brasil: terrestres, aquáticas, parasitas, tóxicas e medicinais. Nova Odessa, SP: O Autor, 1982. 425 p.

LUDLOW, M. M. Light relations of pasture plants. In:WILSON, J. R., Ed. Plant relations in pastures. Melbourne: Commonwelth Scientific and Industrial Research Organization, 1978. p. 35-49.

MACEDO, M.C.M. Pastagens no ecossistema Cerrado: Pesquisa para o desenvolvimento sustentável. In: SIMPÓSIO SOBRE PASTAGENS NOS ECOSSISTEMAS BRASILEIROS: pesquisas para o desenvolvimento sustentável, Brasília. 1995. Anais. Brasília: SBZ, 1995. p. 28-62.

MACEDO, M. C. M.; ZIMMER, A.H. Implantação de pastagens de Brachiaria brizantha cv. Marandu em plantio simultâneo com milho em sucessão à soja em Mato Grosso do Sul. In: REUNIÃO ANUAL DA SBZ, 27., Anais. Campinas-SP: SBZ, 1990. p. 290.

MACHADO, L.A.Z. Manejo de pastagens em sistema integrado lavoura/pecuária. Direto no Cerrado, v.6, n. 21, p. 10, 2001. 
MARTINEZ, H.E.P. Níveis críticos de Fósforo em Brachiaria decumbens (Stapf) Prain , Brachiaria humidicola (Rendle) Schweickerdt, Digitaria decumbens Stent, Hipharrhenia rufa (Ness) Stapf, Melinis minutiflora Pal de Beauv, Panicum maximum Jacq e Pennisetum purpureum Schum. Piracicaba, 1980. 90 p. Dissertação (Mestrado) - Escola Superior de Agricultura “Luiz de Queiroz”, Universidade de São Paulo.

MATHERS, K. Competition and co-operation. Symposia of Society for Experimental Biology, n.15, p. 264-281, 1961.

MATTOS, H.B.; COLAZZA, M.T. Micronutrientes em pastagens. In: SIMPÓSIO SOBRE CALAGEM E ADUBAÇÃO DE PASTAGENS, 1., Nova Odessa, 1985. Anais Piracicaba: Associação Brasileira para Pesquisa da Potassa e do Fosfato, 1986. p. 233-256.

McWILLIAM, J.R. The national and international importance of drought and salinity effects on agricultural production. Australian Journal of Plant Physiology, v. 35, p.1-13, 1986.

MORRIS, R. A.: GARRIT, D.P. Resource capture and utilization in intercropping water. Fields Crop Research, v. 34, p. 303-317, 1993.

NUNES, S. G.; BOOCK, A.; PENTEADO, M. I. O.; GOMES, D. T. Brachiaria brizantha cv. Marandu. Campo Grande: EMBRAPA, CNPGC, 1985. 31p. (EMBRAPA.CNPGC. Documentos, 21).

PITELLI, R. A. Interferência de plantas daninhas em culturas. Informações Agropecuária, v 120, n.11, p.16-27, 1985. 
PREMAZZI, L.M. Saturação por bases como critério para recomendação de calagem em cinco forrageiras tropicais. Piracicaba. 1991. 215 p. Dissertação (Mestrado) Escola Superior de Agricultura “Luiz de Queiroz”, Universidade de São Paulo.

PRIMAVESI, A. Manejo ecológico do solo: a agricultura em regiões tropicais. São Paulo: Nobel, 2002. 549 p.

RADOSEVICH, S. Physiological aspects of competition. In: Weed Ecology. 2 ed. New York: Wiley, 1996. p. 217-301.

RAJCAN, I.; SWANTON, C. Undestanding maize-weed competition: recourse competition, light quality and the whole plant. Fields Crop Research, v.71, p. 139150, 2001.

RICE, E. L. Allelopathy. 2.ed. New York: Academic Press, 1984. 422 p.

ROBBINS, G.B.; BUSHELL, J.J.; MCKEON, G.M. Nitrogen immobilization in decomposing litter contributes to productivity decline in ageing pasture of green panic (Panicum maximum var. Trichoglume). Journal of Agricultural Science, v. 113, n. 3, p. 401-406, 1989.

RODRIGUES, L. R. de A.; RODRIGUES, T. DE J. D.; REIS, R. A. Alelopatia em plantas forrageiras. Jaboticabal: UNESP/FUNEP, 1992. 18 p. (Boletim).

RODRIGUES, L. R. de A.; ALMEIDA, A.R.P. de; RODRIGUES, T. DE J. D. Alelopatia em plantas forrageiras e pastagens. In: SIMPÓSIO SOBRE ECOSSISTEMAS DE PASTAGENS, 2., Jaboticabal, SP, 1993. Anais. Jaboticabal, SP: FUNEP, 1993, p. 100-129. 
ROHRIG, M.; STUTZEL, H. A model for light competition between vegetable crops and weed. European Journal of Agronomy, v. 14, p. 13-29, 2001.

SALISBURY, F. B.; ROSS, C. W. Plant Phisiology. Belmont: Wadsworth, 1991. $459 \mathrm{p}$.

SANCHEZ O., J.F.; SALINAS, J.G. Comportamiento de ocho accesiones de Panicum maximum (Jacq.) en un oxisol de Carimagua, Colombia fertilizado con fosforo y calcio. Acta Agronomica, v.37, n.2, p.36-46, 1987.

SARRUGE, J.R.; HAAG, H.P. Análises químicas em plantas. Piracicaba:ESALQ, Departamento de Química,1974. 56p.

SAS. Statistical Analysis System Institute Incorporation. Version 6.12. 1998.

SEIFFERT, N.F. Gramíneas forrageiras do gênero Brachiaria. Campo Grande: EMBRAPA- CNPGC, 1980. 74p. (EMBRAPA-CNPGC, Circular Técnica, 1).

SHELTON, H.M.; HUMPHREYS, L.R. Pasture establishment in upland rice crops at Na Pheng, Central Laos. Tropical Grassland, v.6, n.3, p.223-228, 1972.

SILVA, W. Interferência de Brachiaria brizantha sobre Eucalyptus citriodora e $\boldsymbol{E}$. grandis, cultivados em solos com diferentes teores de água. Viçosa, 1997. 89 p. Tese (Doutorado) - Universidade Federal de Viçosa.

SILVA, A.A.;JAKELAITIS, A.; FERREIRA, L.R. Manejo de plantas daninhas no Sistema Integrado Agricultura- Pecuária. In: ZAMBOLIM, L.; SILVA, A. A.; AGNES, E.L. Manejo Integrado Integração Lavoura- Pecuária. Viçosa, MG, 2004. p. 117-170. 
SINOQUET, H.; BONHOMME, R. Modeling radioactive transfer in mixed and row intercropping system. Agricultural and Forest Meteorology, v. 62, p. 219-240, 1992.

SKERMAN, P.J.; RIVEROS, F. Tropical grasses. Rome: FAO, 1990. 832 p.

SOARES FILHO, C.V. Recomendações de espécies e variedades de Brachiaria para diferentes condições. In: SIMPÓSIO SOBRE MANEJO DA PASTAGEM, 11., Piracicaba, 1994. Anais. Piracicaba: FEALQ, 1994. p.25-48.

SOUZA NETO, J.M. Época de plantio e adubação de Brachiaria brizantha cv. Marandu e espaçamento do milho como cultura acompanhante, na formação de pastagens. Piracicaba, 1993. 58p. Dissertação (Mestrado) - Escola Superior de Agricultura “Luiz de Queiroz”, Universidade de São Paulo.

STANIZIO, R. M.; LEITE, G.G.; VILELA, L. Efeito alelopático de brachiaria brizantha cv. Marandu sobre o crescimento de plantas de quatro leguminosas forrageiras. In: REUNIÃO ANUAL DA SOCIEDADE BRASILEIRA DE ZOOTECNIA, 28., João Pessoa, PB, 1991. Anais. João Pessoa,: SBZ, 1991. p. 95.

TOLENAAR, M.; NISSANKA, S. P.; AGUILERA, A.; et al. Effect of weed interference and soil nitrogen on four maize hybrids. Agronomy Journal, v. 86, p. 596-601, 1994.

VIEIRA, J. M. Espaçamentos e densidades de semeadura da Brachiaria decumbens, Stapf. Para formação de pastagens. Piracicaba, 1974. 106 p. Dissertação (Mestrado)Escola Superior de Agricultura “Luiz de Queiroz”, Universidade de São Paulo.. 
WALLACE, J.S.; BATCHELOR, C. H.; DABEESING, D.N.; et al. Comparision of the interception and water use of plants and first ratoon sugar cane intercropped with maize. Agricultural and Forest Meteorology, v.57, p.85-105, 1991.

WHITTAKER, R.H.; FEENY, P.P. Allelochemics: Chemical interaction between species. Science, v.171, p.757-70, 1971.

WILLEY, R.W. Intercropping - Its importance and research needs. Part. 1. Competition and yield advantages. Field Crops Abstracts,v.42, n.1, p.1-10. Jan. 1979.

WILLEY, R.W; OSIRU, S.O. Studies on mixture of maize and bean (Phaseolus vulgaris) with particular reference to plant population. Journal of Agricultural Science, v.79,p.517-29. 1972.

WILSON, J. B. Shoot competition and root competition. Journal Applied Ecology, v. 25, n. 2, p. 279-296, 1988.

YOKOYAMA, L.P.; KLUTHCOUSKI, J.; OLIVEIRA, I.P.D.; DUTRA, L.G. GOMIDE, J.C.; BUSO, L.H. Sistema Barreirão: análise de custo/benefício e necessidade de máquinas e implementos agrícolas. Goiânia: EMBRAPA-CNPAF, 1995. 31 p.

ZIMMER, A.H.; EUCLIDES FILHO, K.P. As pastagens e a pecuária de corte brasileira. In: SIMPÓSIO INTERNACIONAL SOBRE PRODUÇÃO ANIMAL EM PASTEJO, Viçosa, 1997. Anais. Viçosa: UFV, 1997. p. 350-379.

ZIMMER, A.H.; MACEDO, M.C.M.; BARCELLOS, A. de O.; KICHEL, A.N. Estabelecimento e recuperação de pastagens de Brachiaria.In: SIMPÓSIO SOBRE MANEJO DE PASTAGEM, 11., Piracicaba, 1994. Anais. Piracicaba: FEALQ, 1994. p. 153-208. 


\section{APÊNDICES}


Apêndice1. Instalação do experimento

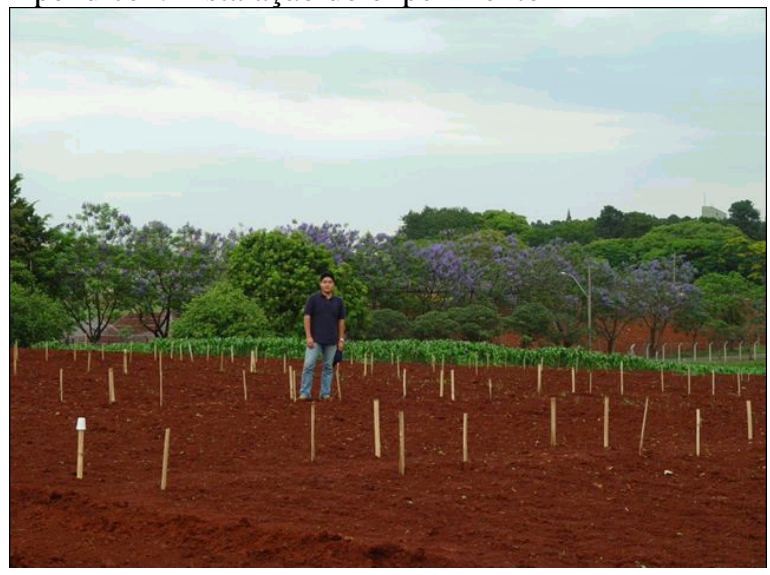

Apêndice 3. Emergência da Brachiaria brizantha

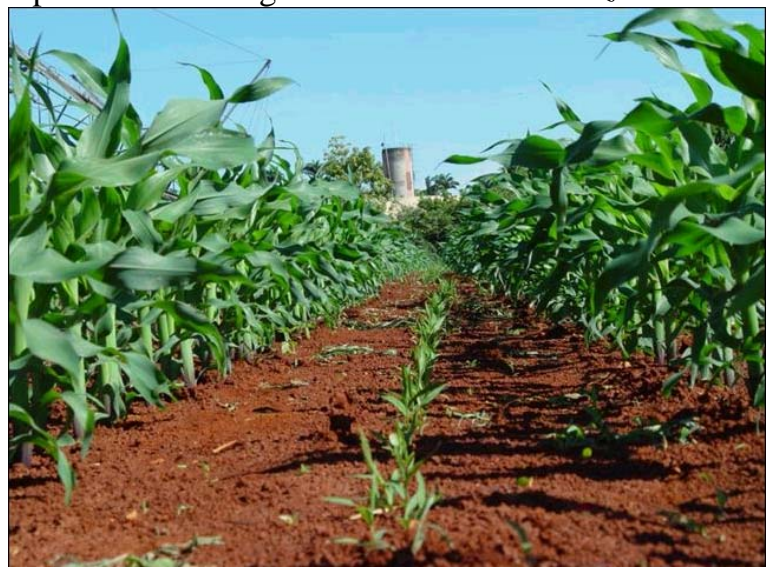

Apêndice 5. B. decumbens

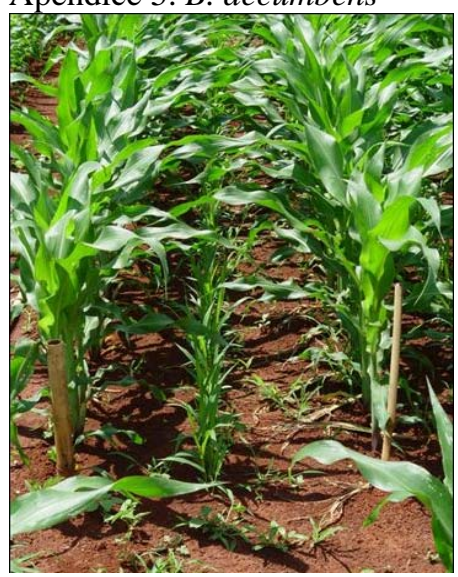

Apêndice 2. Tratamento 1 (testemunha)

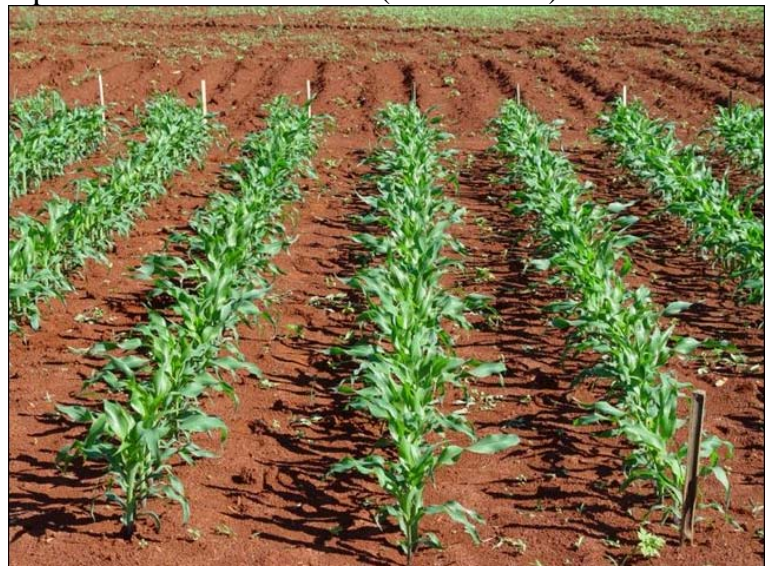

Apêndice 4. B. brizantha

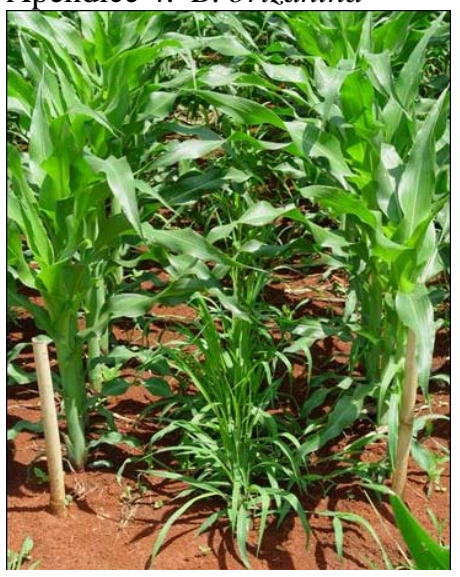

Apêndice 6. B ruziziensis

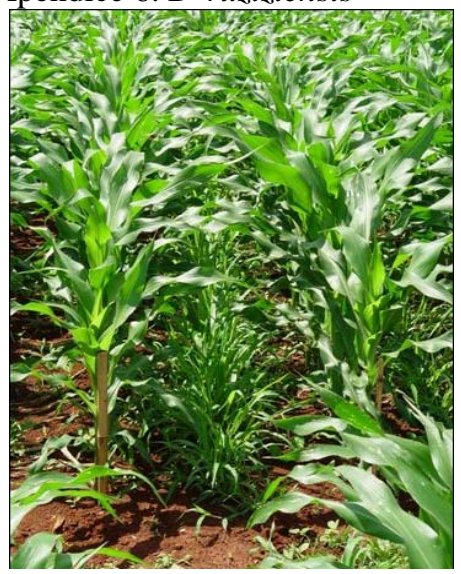


pêndice $7 . \quad$ B. brizantha semeada na mesma data do milho, 35 dias após semeadura

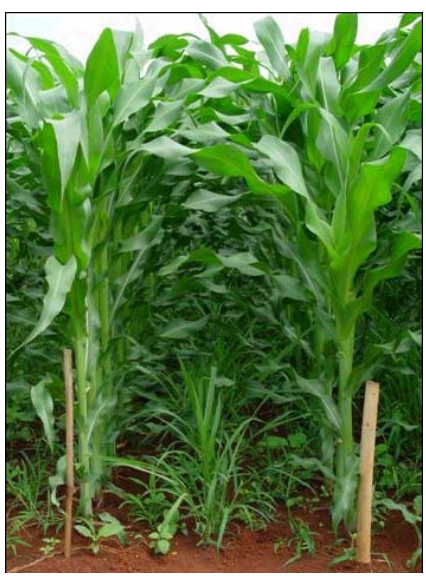

Apêndice 9. B. decumbens semeada na mesma data do milho, 35 dias após semeadura

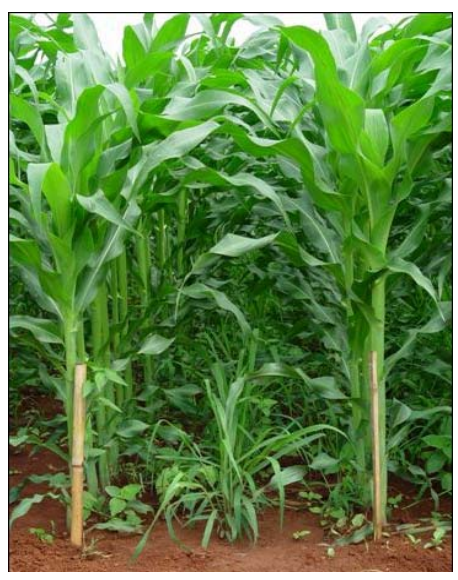

Apêndice 11. B. ruziziensis semeada na mesma data do milho, 35 dias após semeadura

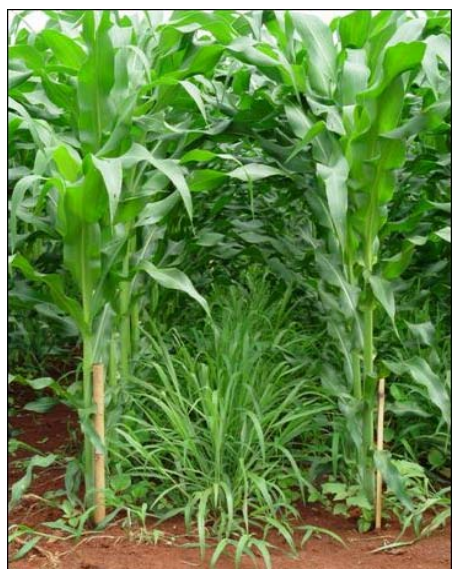

Apêndice $\quad$ 8. B. brizantha semeada com o milho em estádio 1 (quatro folhas), 15 dias após semeadura

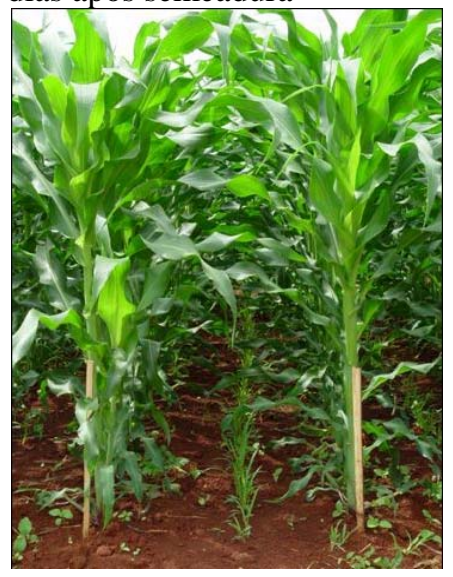

Apêndice 10. B. decumbens semeada com o milho em estádio 1 (quatro folhas), 15 dias após semeadura

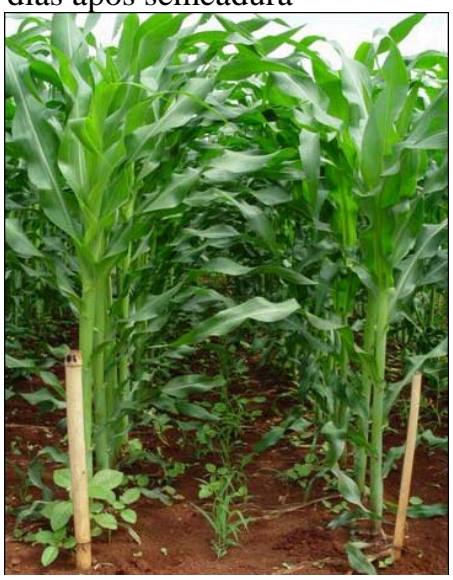

Apêndice 12. B. ruziziensis semeada com o milho em estádio 1 (quatro folhas), 15 dias após semeadura

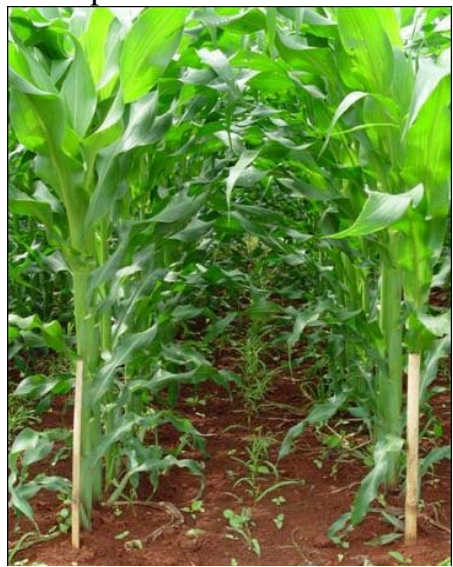


Apêndice 13.Vista geral (Milho em estádio 5)

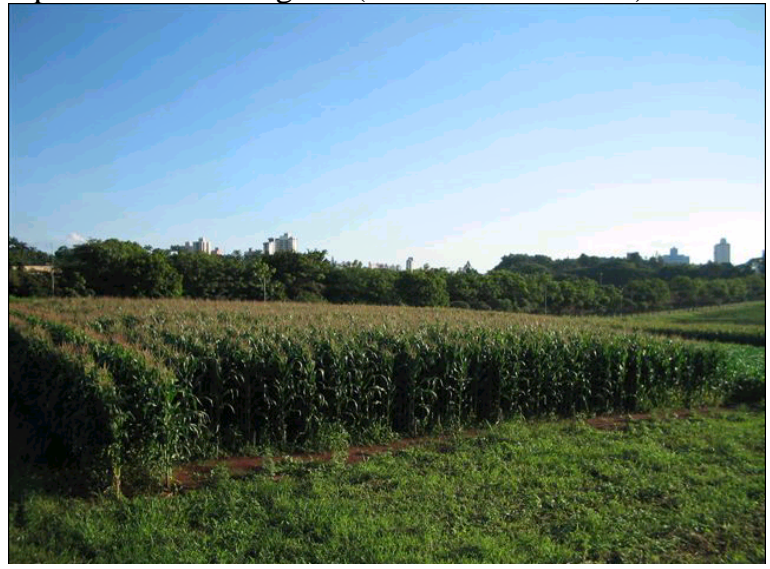

Apêndice 15. Coleta para análise foliar

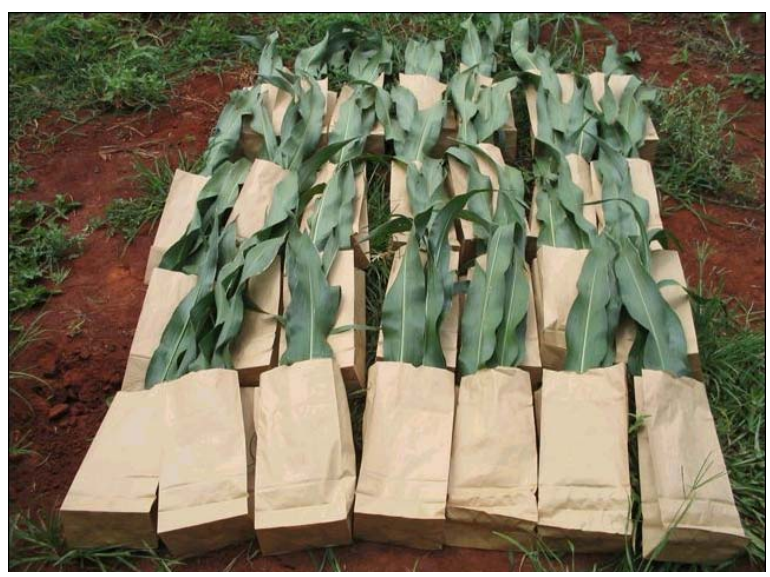

Apêndice $\quad$ 17. Sonda para amostragem de raiz

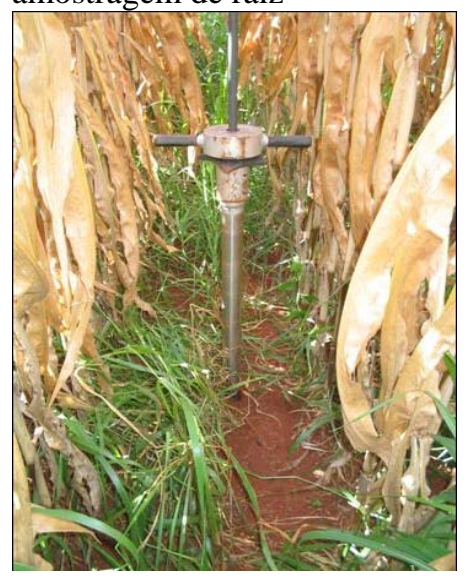

Apêndice 14. LI 3100 (LICOR Nebraska)

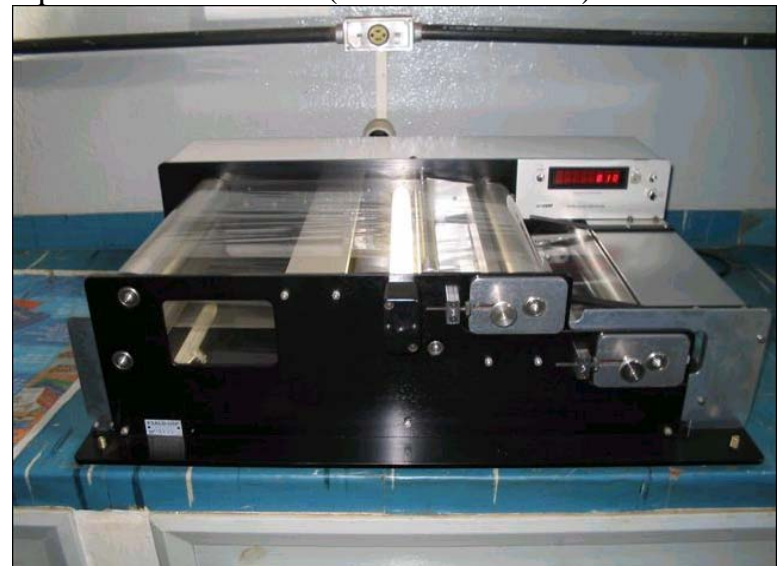

Apêndice 16. Estufa para secagem

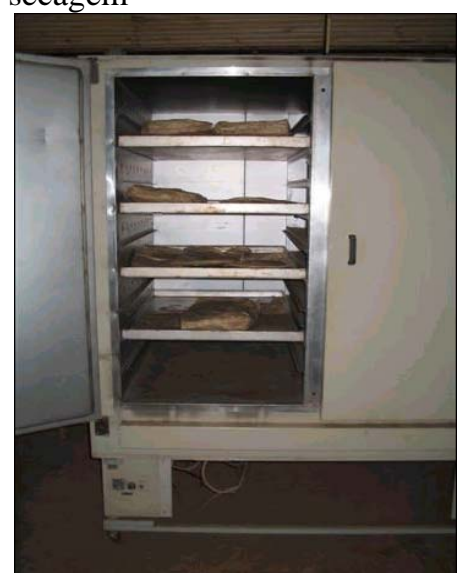

Apêndice 18. Detalhe da amostragem de raiz

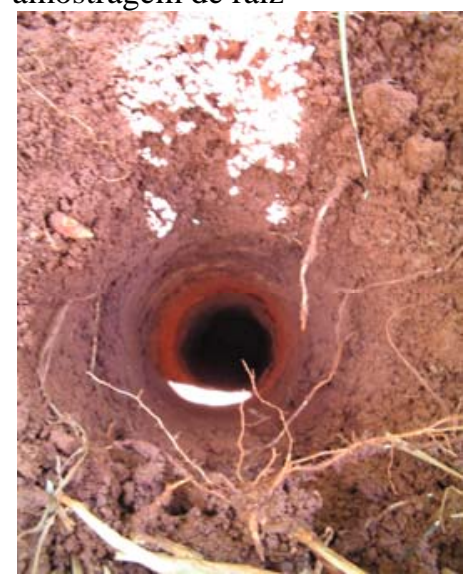


Apêndice 19. Peneiragem de raiz

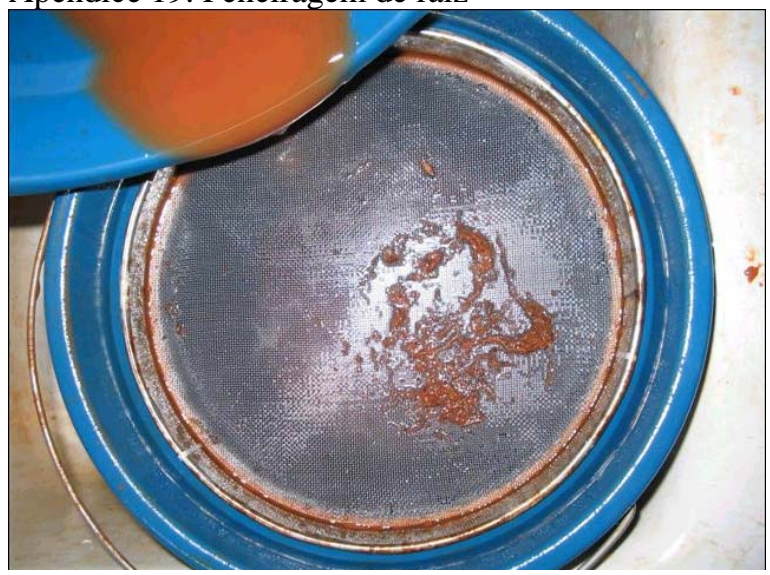

Apêndice 21. Detalhe da

Brachiaria brizantha

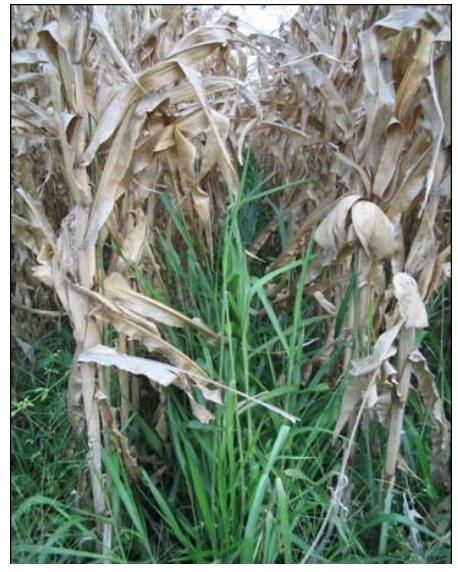

Apêndice 23. Vista geral (15 dias após colheita)

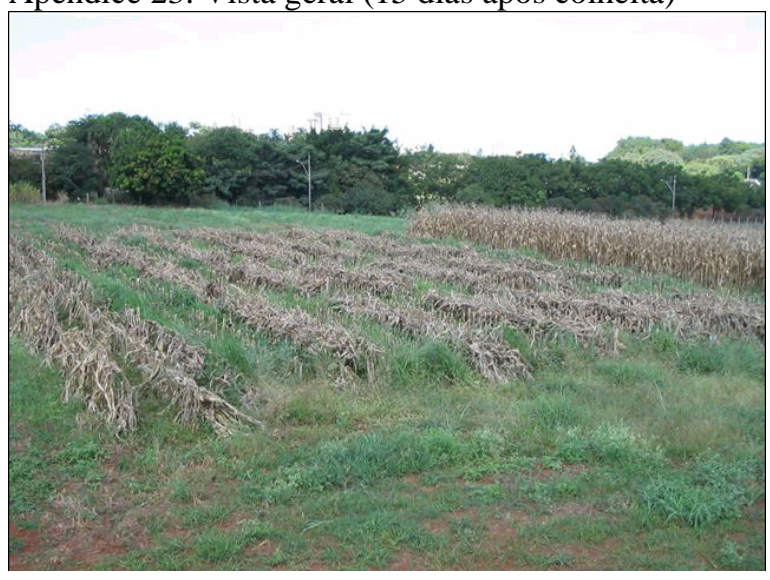

Apêndice 20. Pré-secagem de raízes

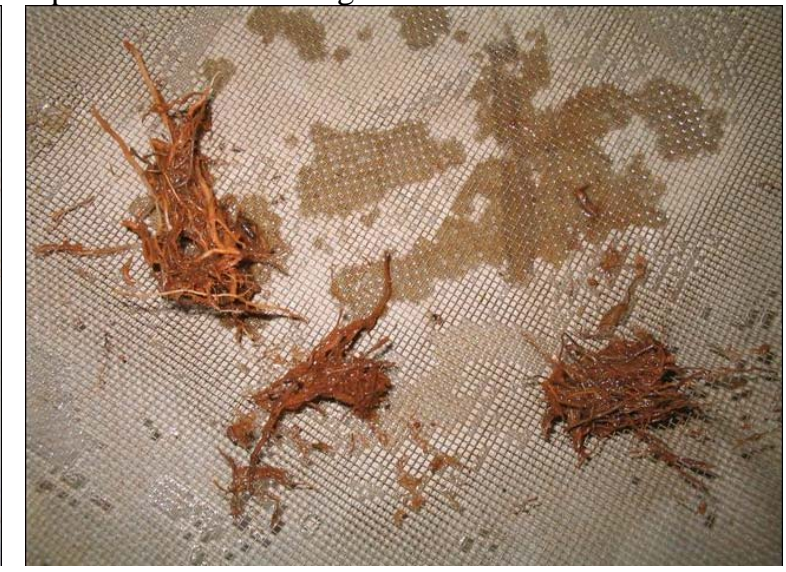

Apêndice 22. Vista geral (Logo após colheita)

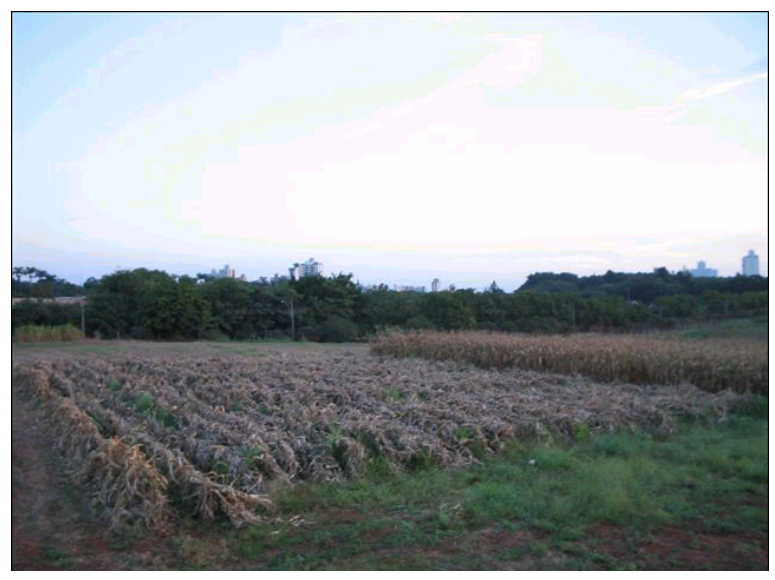

Apêndice 24. Vista geral (30 dias após roçagem)

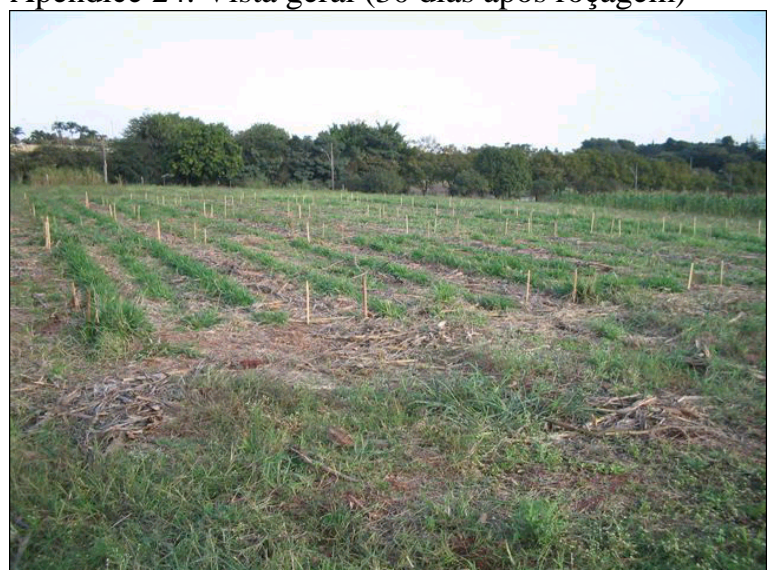

